\title{
Desafios do planejamento na construção do SUS
}

\author{
Washington Luiz Abreu de Jesus \\ Marluce Maria Araújo Assis
}

(orgs.)

JESUS, WLA., and ASSIS, MMA., orgs. Desafios do planejamento na construção do SUS [online]. Salvador: EDUFBA, 2011, 176p. ISBN 978-85-232-1176-9. Available from SciELO Books $<\underline{\text { http://books.scielo.org }>\text {. }}$

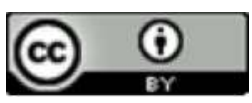

All the contents of this work, except where otherwise noted, is licensed under a Creative Commons Attribution 4.0 International license.

Todo o conteúdo deste trabalho, exceto quando houver ressalva, é publicado sob a licença Creative Commons Atribição 4.0.

Todo el contenido de esta obra, excepto donde se indique lo contrario, está bajo licencia de la licencia Creative Commons Reconocimento 4.0. 
Desafios do Planejamento na construção do SUS 
UNIVERSIDADE FEDERAL DA BAHIA

Reitor

Dora Leal Rosa

Vice-Reitor

Luiz Rogério Bastos Leal

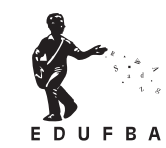

EDITORA DA UNIVERSIDADE FEDERAL DA BAHIA

Diretora

Flávia Goullart Mota Garcia Rosa

\author{
Conselho Editorial \\ Alberto Brum Novaes \\ Angelo Szaniecki Perret Serpa \\ Caiuby Alves da Costa \\ Charbel Ninõ El-Hani \\ Cleise Furtado Mendes \\ Dante Eustachio Lucchesi Ramacciotti \\ Evelina de Carvalho Sá Hoisel \\ José Teixeira Cavalcante Filho \\ Maria Vidal de Negreiros Camargo
}


Washington Luiz Abreu de Jesus

Marluce Maria Araújo Assis

organizadores

Desafios do Planejamento na construção do SUS 
(C)2011 by organizadores.

Direitos para esta edição cedidos à Edufba.

Feito o Depósito Legal.

Projeto gráfico, editoração e capa

Josias Almeida Jr.

Revisão

Eduardo Ross

Normalização

Adriana Caxiado

Sistema de Bibliotecas - UFBA

Desafios do planejamento na construção do SUS / Washington Luiz Abreu de Jesus, Marluce Maria Araújo Assis, organizadores ; prefácio Carmen Teixeira, Rosana Onocko Campos. Salvador : EDUFBA, 2011.

$174 \mathrm{p}$.

Originalmente apresentada como dissertação do autor (mestrado) - Universidade Estadual de Feira de Santana, 2006.

ISBN 978-85-232-0829-5

1. Saúde pública - Planejamento - Brasil. 2. Sistema Único de Saúde (Brasil). 3. Saúde pública - Brasil. 4. Política de saúde - Brasil. I. Jesus, Washington Luiz Abreu de.

II. Assis, Marluce Maria Araújo. III. Teixeira, Carmen. IV. Campos, Rosana Onocko.

\section{Editora filiada à}

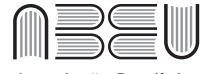

Associação Brasileira das Editoras Universitárias

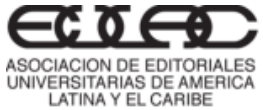

LATINA Y EL CARIBE

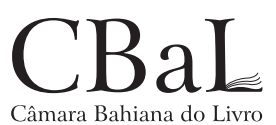

Câmara Bahiana do Livro

\section{EDUFBA}

Rua Barão de Jeremoabo, s/n, Campus de Ondina,

40170-115 Salvador-BA Brasil

Tel/fax: (71)3283-6160/3283-6164

www.edufba.ufba.br | edufba@ufba.br 


\section{AGRADECIMENTO}

Este livro é resultado de um investimento pessoal de muitos anos. Também revela o "eu" coletivo que existe em mim, que se demonstra nas parcerias que

busco para realizar meus intentos. Aproveito para agradecer aos amigos de ontem e de hoje que acreditam nas minhas propostas [sem nominá-los, porém com afeto e gratidão]. Agradeço especialmente à minha família pelo apoio nos meus projetos de vida e pelo amor que me dedicam. Muito Obrigado! 



\section{PREFÁCIO}

9 Planejamento em saúde: uma retomada necessária (I)

11 Planejamento em saúde: uma retomada necessária (II)

13 Apresentação

\section{CAPÍTULO 1}

17 Os Caminhos do Pensamento e a construção de uma Trajetória Washington Luiz Abreu de Jesus

Marluce Maria Araújo Assis

\section{CAPÍTULO 2}

29 Planificação em saúde na América Latina: uma construção histórico-social

Washington Luiz Abreu de Jesus

Marluce Maria Araújo Assis

Chaider Gonçalves Andrade

Sisse Figueredo de Santana

\section{CAPÍTULO 3}

61 Planejamento em saúde no Brasil: configurações e tendências no sistema e nos serviços de saúde Washington Luiz Abreu de Jesus Marluce Maria Araújo Assis Sisse Figueredo de Santana Chaider Gonçalves Andrade

\section{CAPÍTULO 4}

79 Revisão sistemática sobre o conceito de acesso nos serviços de saúde: contribuições do planejamento

Washington Luiz Abreu de Jesus

Marluce Maria Araújo Assis 


\section{CAPÍTULO 5}

99 Planejamento em saúde e poder: dimensões teóricas de análise Washington Luiz Abreu de Jesus

Marluce Maria Araújo Assis

\section{CAPÍtULO 6}

125 Sujeito e Práxis: tensão, conflito e complexidade na discussão do planejamento no campo da Saúde Coletiva

Washington Luiz Abreu de Jesus

Marluce Maria Araújo Assis

\section{CAPÍTULO 7}

149 Ponto de chegada para iniciar uma nova caminhada Washington Luiz Abreu de Jesus

POSFÁCIO

155 Princípios e Diretrizes do SUS: expressões de uma luta histórica do povo brasileiro

Washington Luiz Abreu de Jesus

ANEXO

165 Sistematização da produção bibliográfica de referência (Base de dados SciELO/1990-2010)

173 Organizadores e autores 


\section{PREFÁCIO}

\section{Planejamento em saúde: uma retomada necessária (I)}

Estamos imersos em um tempo de incertezas. Dúvidas, indecisão, perplexidades diante da velocidade das transformações contemporâneas, na economia, na política, na cultura, na vida cotidiana. Mudanças que influem na subjetividade e nos fazem questionar os referenciais que constituem as lentes através das quais observamos e nos posicionamos diante do mundo, da vida, dos conhecimentos e do trabalho que realizamos, em nosso caso, no âmbito da Saúde Coletiva brasileira e, especificamente, na área de Política, Planejamento, Gestão e Avaliação de sistemas e serviços de saúde.

Impossível, portanto, não estarmos inquietos, buscando refletir sobre o que nos torna o que somos, como pensamos, em que coordenadas nos movemos, que limites nos cercam, que desafios definimos para ultrapassar. Nesse sentido, damo-nos conta da importância que tiveram, na formação do nosso vocabulário, na linguagem com que apreendemos nossos objetos de estudo e nossos campos de prática, a elaboração e difusão de textos de planejamento, contendo propostas teórico-metodológicas, como foi o caso do método CENDES-OPS, o documento do CCPS, os textos de Mário Testa e de Carlos Matus. Ademais, percebemos o significado do debate que estes inauguraram e ajudaram a desenvolver, estimulando a redação de outros textos que analisam as noções, conceitos, técnicas e instrumentos de planejamento e programação, refletindo sobre sua pertinência, seu significado, as possibilidades de uso, as armadilhas em que nos lançaram ou as avenidas que abriram para que pudéssemos reconstruir nossa visão de mundo e nossas práticas no dia-a-dia do processo de Reforma Sanitária e de construção do SUS nos últimos anos.

De fato, aqueles que como Washington Abreu, Marluce Assis, Chaider Andrade e Sisse Santana, se embrenharam na leitura, na busca de compreensão e crítica das propostas teórico-metodológicas elaboradas e difundidas no que hoje constitui a área de Política, Planejamento, Gestão 
e Avaliação em Saúde, sabem o quanto foi importante incorporar ao vocabulário corrente nos processos de formação de pessoal em saúde, noções e conceitos como "necessidades de saúde"; "programação"; "normas técnicas"; "análise de situação"; "imagem-objetivo"; "viabilidade"; "proposições políticas"; "desenho estratégico"; "governabilidade"; e tantas outras que tendem a se tornar senso comum entre aqueles que militam e trabalham nas instituições gestoras do SUS em todas as esferas de governo.

Pois bem, por isso mesmo é bem vindo o trabalho desses autores. Revisitando os "clássicos" de nossa área, operando uma releitura que tenta colocar sob análise permanente os sentidos e significados que vêm sendo atribuídos a este empreendimento científico-técnico que envolveu um conjunto heterogêneo de pesquisadores e docentes engajados na reflexão, na experimentação e na análise crítica dos referenciais teóricos e das possibilidades de prática de planejamento, Washington Abreu e Marluce Assis oferecem aos leitores uma visão acerca do planejamento em saúde que, sem dúvida, estimulará a continuidade do debate na área.

Mais que isso, entretanto, penso que o conjunto de ideias contidas neste livro alimentará a necessária qualificação das práticas de planejamento que se realizam, por imposição de normas e portarias e/ou por vontade política dos gestores, como mero ritual burocrático ou buscando instituir-se como espaço democrático de tomada de decisões, lugar da repetição ou espaço para a construção da diferença...

Enfim, ao tempo em que saúdo os autores, expresso meu desejo de que este livro cumpra a finalidade a que se propõe: ser adubo e semente, subsídio ao processo de formação de sujeitos interessados em conhecer, criticar e intervir sobre a situação da saúde, munidos de uma racionalidade técnica, política e, por que não, ética, da qual os múltiplos conceitos e métodos do planejamento em saúde façam parte.

Carmen Teixeira Julho de 2011 


\section{Planejamento em saúde: uma retomada necessária (II)}

A existência de um novo livro sobre Desafios do Planejamento na construção do SUS, de Washington Luiz Abreu de Jesus e Marluce Maria Araújo Assis, merece ser saudada. Fruto de um árduo processo de pesquisa, Washington e Marluce nos oferecem um livro original, oportuno e relevante que revisita tradições, comenta a literatura brasileira recente e encara os desafios do SUS neste século XXI tão veloz.

No campo das políticas públicas no Brasil, e particularmente nas políticas de saúde, a retomada da temática do planejamento é hoje tão imprescindível quanto rara. 0 planejamento como disciplina, tal como o conhecemos no século $\mathrm{XX}$, parece ter caído morto junto com as sobras do muro de Berlim. Há uma tentativa de construir uma neo-hegemonia teórica no Brasil que louva a criação e inovação como se elas pudessem ser fruto da improvisação e da falta de planejamento. Porém, ele não seria mesmo mais necessário? Poderiam as políticas públicas e o Sistema Único brasileiro prescindir de um planejamento? Enquanto alguns tentam fazer o Estado brasileiro desistir de planejar e dar racionalidade às suas ações, alguém acredita que as instituições lucrativas e privadas não planejam? Não tentam algum tipo de cálculo estratégico sobre seus próximos passos e investimentos?

Desistir de interferir no futuro, isso seria desistir do Planejamento para Matus. Contribuir para a constituição de atores sociais que possam inserir temas na agenda de governo seria o desafio para Testa. Ambas as questões parecem-nos hoje tão importantes quanto outrora.

A escola baiana utilizou o planejamento exemplarmente para a construção concreta de sistemas locais de base territorial, numa integração fundamental com a epidemiologia e suas informações. Outros autores no Brasil tem nos chamado a atenção para a importância dos aspectos comunicativos, organizacionais e até interpretativos, visando aproximar o planejamento dos processos micro, que permeiam os debates nos serviços e na organização cotidiana do trabalho. Nenhuma dessas contribuições e 
debates escapou aos autores desta obra, que, contudo, se propuseram a trilhar um novo caminho, mas sempre bem alavancados pelas tradições da área.

Os entraves, os desafios do sistema e da gestão pública de saúde, são todas questões que poderão ser iluminadas pela leitura fluida e agradável a que o livro de Washington e Marluce nos convida. Que seja uma vez mais bem-vindo!

Rosana Onocko Campos

Julho, 2011 


\title{
Apresentação
}

\author{
Cortar o tempo \\ Quem teve a idéia de cortar o tempo em fatias, \\ a que se deu o nome de ano, foi um indivíduo genial. \\ Industrializou a esperança, fazendo-a funcionar no limite da exaustão. \\ Doze meses dão para qualquer ser humano se cansar e entregar os pontos. \\ Aí entra o milagre da renovação e tudo começa outra vez, com outro número e \\ outra vontade de acreditar que daqui pra diante vai ser diferente.
}

Carlos Drummond de Andrade.

O poema de Carlos Drummond de Andrade em epígrafe nos inspira, e por que não dizer, nos ilumina, para pensarmos que sempre é possível renovar, começar de novo e procurar fazer diferente. Nos últimos 15 anos temos refletido sempre em busca de novas alternativas que possibilitem construir um planejamento no Sistema Único de Saúde (SUS) como dispositivo mediador de mudanças, uma ferramenta importante para ajudar a pensar sobre o sujeito que governa e que também não governa, mas é parte deste sistema, quer seja trabalhador ou usuário.

Este livro é uma síntese desta inquietação, inspirado na Dissertação de Mestrado de Washington Luiz Abreu de Jesus, intitulada Re-significação do Planejamento no campo da saúde coletiva: desafios teóricos e busca de novos caminhos, do Programa de Pós-Graduação em Saúde Coletiva da Universidade Estadual de Feira de Santana, defendida em 2006, sob nossa orientação, traduz a construção de sujeitos implicados com o SUS, recortando dimensões teóricas e conceituais que sustentam o planejamento em saúde, de forma instigante, atual e desafiadora.

Reconhecemos a influência de autores, considerados clássicos no campo do planejamento crítico e estratégico, como Mário Testa e Carlos Matus, e procuramos fazer uma releitura do pensamento destes autores, a partir da construção histórico-social e da produção científica da área de 
Políticas, Planejamento e Gestão em Saúde nos últimos 20 anos e suas contribuições para a construção do SUS.

O SUS, concebido no seu arcabouço institucional, contempla princípios doutrinários, a universalidade, a equidade e a integralidade nos serviços e ações de saúde, além de diretrizes organizacionais que consistem na descentralização, regionalização e hierarquização da rede de serviços e participação social. Estes princípios e diretrizes representam importantes instrumentos capazes de induzir mudanças no modelo de atenção à saúde e no processo de trabalho dos diferentes sujeitos sociais que constroem as suas práticas no dia-a-dia dos serviços de saúde. Todavia, o planejamento estratégico, participativo e democrático continua muito distante do cotidiano dos gestores, trabalhadores e usuários do sistema de saúde, apesar de ainda representar uma "imagem-objetivo" a ser alcançada pelos diferentes interlocutores que defendem uma saúde pública, universal e resolutiva.

Evidenciamos, portanto, que movimentos e questionamentos vêm sendo edificados, demonstrando o compromisso dos diferentes sujeitos em vários municípios brasileiros, incluídos os autores deste livro, pelo envolvimento no processo de construção do sistema público de saúde, retratado na prática da gestão e academia.

A produção a ser apresentada adiante suscita olhares críticos, com capacidade para analisar e refletir sobre o planejamento em saúde em suas inúmeras perspectivas. Ou seja, articular as dimensões de análises teóricas produzidas com a melhoria da realidade do SUS em diferentes contextos: local, regional e nacional.

Além disso, importante contribuição pode ser dada com a divulgação deste livro, no sentido de disparar motivações para a construção do novo, de novas perspectivas do planejamento em saúde. Esperamos, também, agregar conhecimento ao arsenal já existente sobre a temática, contribuindo com suas discussões teóricas, metodológicas e conceituais. Um esforço conjunto na construção do SUS.

As inquietações apontadas até aqui permitem apresentar agora ao leitor como o livro está organizado. 
O primeiro capítulo traça o caminho percorrido para construir o objeto de estudo e a trajetória metodológica, ao tempo em que sistematiza, traz à baila os momentos hermenêuticos e dialéticos, a objetividade e a subjetividade, dentro de uma perspectiva crítica, reflexiva e contextualizada. Nesse sentido, busca apreender o planejamento em saúde no campo da Saúde Coletiva, como uma combinação de saberes e práticas acumuladas no processo de constituição da Reforma Sanitária brasileira.

O segundo capítulo resgata a construção histórico-social da planificação em saúde na América Latina, revisitando as concepções teórico-metodológicas do planejamento em saúde no cenário brasileiro e as diferentes correntes do planejamento no campo da Saúde Coletiva. Para tanto, demarcamos a busca de novas tecnologias para a gestão do sistema e dos serviços de saúde.

O terceiro capítulo instiga o leitor a fazer um passeio pelas configurações e tendências do planejamento no sistema e serviços de saúde no contexto brasileiro. As tendências apresentadas discutem o sujeito da transformação no planejamento e as propostas alternativas no processo de gestão nos diferentes níveis de complexidade da atenção no SUS. Os enfoques resgatam a questão do planejamento enquanto uma possibilidade a ser construída como ferramenta balizadora da reforma do sistema de saúde brasileiro.

No quarto capítulo apresentamos uma análise das concepções teóricas e conceituais de acesso aos serviços de saúde, contemplando o processo de construção do SUS, com um olhar analisador que procura estabelecer conexões entre a discussão teórica e a prática do planejamento no campo da Saúde Coletiva.

o quinto capítulo é instigante e reflexivo, na medida em que adotamos como tarefa construir uma nova abordagem, já que o tema já foi deveras explorado e, no nosso entender, o poder se estabelece como um desafio teórico e conceitual, pois é necessário ressignificá-lo e redimensioná-lo. Para tanto, discutimos que o poder aliado ao planejamento está relacionado a componentes técnicos, políticos e administrativos articulados entre si, na atuação dos sujeitos nas instituições de saúde. 
O sexto capítulo permite viajar na discussão de sujeito e práxis, buscando apreender as concepções de tensão, conflito e complexidade, entendendo que as relações que se estabelecem entre os sujeitos são sempre dialéticas, sendo, portanto, tensas, conflitantes e complexas.

As considerações finais convidam o leitor a repensar as suas práticas como um ponto de chegada para iniciar uma nova caminhada. Como diz o poeta, citado no início do texto, "é o milagre da renovação e tudo começa outra vez", para construímos a mudança, a transformação...

Boa leitura...

Marluce Maria Araújo Assis

Julho de 2011 


\section{CAPÍTULO 1}

\section{Os Caminhos do Pensamento e a construção de uma Trajetória}

Washington Luiz Abreu de Jesus

Marluce Maria Araújo Assis

[...] sem sequer poder negar a desesperança como algo concreto e sem desconhecer as razões históricas, econômicas e sociais que explicam, não entendendo a existência humana e a necessária luta para fazê-la melhor sem a esperança, sem o sonho [...] Freire, 1992.

\section{INTRODUÇÃO}

A humanidade, desde os primórdios de sua existência, se preocupa com a organização de seu trabalho. Já nos tempos remotos da história, o homem utilizava saberes e práticas do senso comum para organizá-lo, de modo a concretizar seus intentos.

Se mirarmos as pirâmides do Egito, os templos dos faraós, as muralhas da China, as construções milenares do Oriente Médio, as edificações greco-romanas, as cidades sagradas dos impérios indo-americanos, dentre outros grandes monumentos da humanidade, identificamos como essas civilizações utilizaram os seus melhores cálculos para produzir estruturas de tamanha grandeza e importância, na busca de seus diferenciados graus de liberdade. Desde aquele momento já se colocava na pauta a necessidade de se "planejar", mesmo com base nos conhecimentos da época.

$\mathrm{O}$ ato de se organizar para produzir se apresenta, portanto, como um movimento individual e coletivo do homem, conduzindo o curso dos acontecimentos à sua vontade, transformando-se num processo social de mudanças, que se consolida em realizações caracterizadas como os resultados deste ato, que na atualidade se denomina como "ato de planejar". 
O Dicionário Houaiss de língua portuguesa (2001) define "planejamento" como

[...] o ato ou efeito de planejar; serviço de preparação de um trabalho, de uma tarefa com o estabelecimento de métodos convenientes; planificação; determinação de um conjunto de procedimentos, de ações visando à realização de um determinado projeto; elaboração de planos governamentais, especialmente nas áreas econômica e social.

Tancredi, Barrios e Ferreira (1998) complementam a definição de planejamento ao destacarem que planejar é a arte de elaborar o plano de um processo de mudança. Compreende um conjunto de conhecimentos práticos e teóricos ordenados de modo a possibilitar interação com a realidade, programar as estratégias e ações necessárias, e tudo mais que seja delas decorrente, no sentido de tornar possível alcançar os objetivos e metas desejadas e nele pré-estabelecidos.

Na realidade, para esses autores, o planejamento parte do princípio que o sujeito que planeja tem a capacidade de conduzir processos de mudança, por possuir um conjunto de conhecimentos teóricos e práticos relacionados à sua qualificação técnica e experiência. Conhecimento esse que, na perspectiva apresentada, pode possibilitá-los a programarem-se, no sentido de tornar possível o alcance dos propósitos estabelecidos numa dada organização. Possibilita a interação com a realidade tanto no plano econômico quanto no social.

Para Teixeira (2001), o planejamento envolve um conjunto de questões de natureza teórica, metodológica, técnica e instrumental - que se conformam ao longo do seu desenvolvimento enquanto prática social -, sendo um campo de constantes reflexões e experimentações, na medida em que diferentes abordagens e enfoques interagem e se acumulam em função da redefinição das demandas e necessidades historicamente determinadas. Ao incorporar ao planejamento elementos da prática social, a autora confere ao mesmo a acumulação e a interação necessária à ideia de processo, de construção, de historicidade.

R. Campos (2001) complementa essa discussão conceitual ao apresentar que $o$ ato de planejar poderia ser uma atividade "quase natural" ao homem, que ao buscar incorporá-lo na sua práxis, consolida a ideia de que 
a sociedade onde vive possa ser eficaz. Diante dessa concepção de planejamento, deve-se estabelecer uma relação de funcionalidade - ligação entre o planejamento instrumental e o cotidiano das pessoas -, entre os meios e os fins do processo de planejar, dirigindo-o (o planejamento) racionalmente, para a obtenção de resultados significativos, numa visão denominada como teleológica, a partir de algumas características explicitadas a seguir:

- O planejamento é construído historicamente, através da programação de ações e estratégias que visam estabelecer uma correlação teleológica;

- O planejamento resgata sua essência instrumental, sem omitir, entretanto, a subjetividade das pessoas que com ele operam, mostrando-se, também, como uma atividade com "valor de uso", pois os seus operadores buscam ademais sua realização pessoal.

A discussão teórica levantada para a produção deste livro, aliada ao fato de há quase dez anos estarmos investindo na construção de um conhecimento sobre a temática ${ }^{1}$, trouxe reflexões acerca das diversas perspectivas do planejamento em saúde no cenário do Sistema Único de Saúde (SUS).

O nosso ponto de partida é a década de 1990, que impõe sua importância como o período de definição do papel de cada esfera de governo na organização do sistema de saúde brasileiro e da construção do arcabouço jurídico-normativo, além de trazer o concomitante desenvolvimento dos principais núcleos acadêmicos de trabalho sobre o tema Planejamento ligados à causa da saúde. Nesse período (1990-1999) são divulgadas as Normas Operacionais Básicas do SUS (NOB-SUS) e se institui o planejamento local / participativo no contexto da municipalização da saúde.

1 Importa destacar que desde 2001 o primeiro autor deste livro vem participando de processos de gestão e qualificação profissional na área de PP\&G em saúde, tendo ocupado vários cargos importantes na gestão do SUS nos âmbitos municipal e estadual do sistema, e realizado diversos cursos de pós-graduação com ênfase na área. Este livro, por exemplo, é fruto de um trabalho de equipe, revisando sua dissertação de mestrado, cujo título é Re-significação do planejamento no campo da Saúde Coletiva: desafios teóricos e busca de novos caminhos, defendida em 26 de junho de 2006, na Universidade Estadual de Feira de Santana - Bahia. 
Na década passada (anos 2000), com as Normas Operacionais da Assistência à Saúde no SUS (NOAS-SUS) e com o Pacto pela Saúde, institui-se o olhar sobre a questão da regionalização do sistema e dos serviços, e sobre a necessidade de fortalecimento da função gestora do planejamento. Fato que se explicita pela proposição do Plano Diretor de Regionalização (PDR), consolidação da Programação Pactuada e Integrada (PPI), construção do Sistema de Planejamento do SUS e pela inserção da temática do planejamento dentre os compromissos do Pacto de Gestão.

Os desafios que se apresentaram nessas décadas no processo de implementação do SUS podem ter impulsionado os movimentos pela institucionalização do planejamento no sistema e vêm provocando a academia na produção de subsídios teórico-metodológicos que dêem conta de articular teoria e prática, intenção e realidade, racionalidade instrumental e subjetividade do cotidiano.

Estudar esse processo prescinde, antes de tudo, de uma análise acerca da produção teórica, tomando como fontes os artigos publicados sobre Planejamento em Saúde nos principais periódicos nacionais da área de Saúde Coletiva, no período de 1990-2010. Para tanto, buscamos neste livro discutir as concepções teórico-metodológicas e compreender as abordagens teóricas acerca de questões como: acesso aos serviços de saúde, poder e sujeito/ator social no processo do planejamento, conforme os conhecimentos produzidos pelos pesquisadores da área.

Diante do exposto, colocamo-nos a construir o pressuposto teórico que fundamentou o raciocínio do estudo que deu origem a este livro. Estabelecemos, então, uma conexão entre a teoria e a prática, fundamentando o estudo com afirmações concretas para garantir a totalidade possível do objeto, tanto no sentido teórico-conceitual quanto histórico.

Desse modo, temos como pressuposto teórico que o Planejamento em Saúde no Brasil vem se constituindo no campo da Saúde Coletiva, engendrado pelas concepções teórico-metodológicas do Enfoque Estratégico, enriquecido com as perspectivas do agir comunicativo, análise institucional e da participação como princípio. Representa uma combinação de saberes e tecnologias acumuladas no processo de constituição da Reforma Sanitária para garantir o acesso aos serviços de saúde, permeado por 
conflitos e contradições nas arenas decisórias dos espaços de poder, para a manutenção, mudança ou transformação da realidade social. Outrossim, vem incorporando de modo diversificado a questão do sujeito/ator social nos diferentes contextos e modelos teórico-práticos desenvolvidos por aqueles que discutem o planejamento numa perspectiva crítica, comunicacional e estratégica.

Então, vamos à busca de testificar o pressuposto! Compreendendo, entretanto, que em ciência nada se cria, tudo se transforma.

\section{TRAJETÓRIA METODOLÓGICA E RECONSTITUIÇÃO EPISTEMOLÓGICA}

Procuramos, nesta parte, apresentar os caminhos da compreensão do objeto do Planejamento em Saúde no Brasil, a partir do recorte temporal de vinte anos (1990-2010), período de consolidação do Sistema Único de Saúde enquanto perspectiva de organização de um modelo nacional de atenção à saúde.

Tomamos como base, neste momento e nos que se seguem, os trabalhos de Minayo (2004); Minayo e Deslandes (2002); Gadamer (2004); Testa (1997); e Baremblit (2002), dentre outros que conformaram o sentido metodológico do estudo que deu origem a este livro.

Os autores em epígrafe nos auxiliaram a compreender os porquês e os senões da perspectiva metodológica que adotamos - conjugar hermenêutica e dialética, o que entendemos não ser tarefa fácil. Mas aceitamos o desafio porque concordamos com o que diz Minayo e Deslandes (2002), em síntese:

[...] a hermenêutica é a arte da compreensão [...]. A dialética é a arte do estranhamento e da crítica [...]. Para se fazer hermenêutica se deve ter consciência histórica; idéia de movimento, de liberdade, de necessidade, de força; entendimento da noção de símbolo, significado, intencionalidade e empatia. Para se fazer dialética se deve ter consciência da realidade social; idéia de processo, transformação, mudança; e entendimento da noção de contradição, crítica e negação [...].

O sentido hermenêutico é apresentado a partir da "interpretação temática" de Ferrater-Mora (1941) e da "autocompreensão" de Habermas 
(1989), bases teórico-conceituais analisadas por Minayo e Deslandes (2002). Significa a compreensão simbólica da realidade a ser interpretada, a partir da busca do sentido que se dá na "comunicação", na retórica e na práxis. Também aponta para a busca do entender que as respostas a determinados questionamentos surgem no âmago do próprio tema, com a explicação dos elementos constituintes dele mesmo. Outrossim, o exercício hermenêutico busca um consenso possível.

Neste ponto encontramos o caráter de inflexão da hermenêutica e sua aproximação com a dialética - a busca de uma "unidade perdida", que reforça a ideia de que o contraditório existe, portanto o que se quer com um estudo na perspectiva dialética é estabelecer um diálogo possível entre os contraditórios, o que se caracterizará como uma "unidade de contrários".

O caráter de inflexão da hermenêutica enquanto componente do método interpretativo é um caráter de verdades identificadas a partir da arte da compreensão. Seria, como explicitado por Gadamer (2004), um empenho em reconstruir na compreensão a determinação original de uma obra, um "ponto de conexão" para reproduzir a originalidade numa operação auxiliar verdadeiramente essencial.

Gadamer (2004) afirma que a hermenêutica é uma espécie de inversão rumo à retórica e à poética, tendo como elementos o convencimento e a linguagem. Reafirmamos, então, a inflexão da hermenêutica com a dialética na construção do método de análise, pois o convencimento só é possível onde há contradições a serem superadas. Contradições essas que tratam de aspectos filosóficos, ideológicos, conceituais, teóricos e metodológicos, que, no nosso entendimento, não podem ser tratados na sua completude apenas como um único caminho para a análise de dados, aqui compreendidos como métodos de análise utilizados isoladamente no tratamento dos dados de uma pesquisa, sendo métodos quantitativos ou qualitativos.

O caminho de construção teórico-metodológica teve como momentos o ponto de partida, uma aproximação com o objeto de estudo; as paradas (para refletir) ${ }^{2}$, momentos em que foi necessário aprofunda-

2 Podemos identificá-las como instantes de "tensão hermenêutica" em que o conhecimento acumulado conflita com o conhecimento produzido no que se refere à compreensão, trazendo-nos a ne- 
mento teórico para compreender o significado hermenêutico do trabalho que estávamos realizando. As etapas referem-se aos movimentos operacionais da pesquisa, isto é, onde o pesquisador apresenta sua trajetória propriamente dita, seus métodos para dar conta do objeto a ser estudado; e o processo de análise propriamente dito, instantes analíticos, ligados conceitualmente à concepção do método hermenêutico-dialético proposto por Minayo e Deslandes (2002).

Como ponto de partida, tivemos o encontro com o objeto de investigação e com a teoria da pesquisa qualitativa em saúde, momento em que nos apropriamos dos conceitos fundamentais da abordagem para optar por essa perspectiva. Este momento possibilitou uma leitura sobre os livros produzidos na área da Saúde Coletiva, com ênfase nos que tomaram o planejamento em saúde como objeto de estudo.

Descoberta a motivação, avançamos com a primeira etapa metodológica, onde foram levantados os periódicos de circulação nacional e internacional com sede no Brasil, do campo da Saúde Coletiva, por meio da listagem de periódicos referenciados no Qualis Capes, excluindo desta amostra periódicos locais, de áreas específicas, e que não estão na base de dados da Scientific Electronic Library Online (SciELO), escolhida pelo fato de se tratar de uma biblioteca eletrônica que tem como conteúdo uma coleção selecionada de periódicos científicos brasileiros, e por ser o resultado de um projeto integrado entre as entidades de fomento à pesquisa (FAPESP ${ }^{3}$, BIREME $^{4}$ e CNPq ${ }^{5}$ ). Para proceder este levantamento foi utilizado o endereço eletrônico da Internet (www.scielo.br).

A primeira parada se configurou como o momento das reflexões teóricas sobre o conhecimento, a ciência e o senso comum em pesquisa qualitativa, onde extraímos os conceitos fundamentais desses temas no campo das Ciências Sociais aplicadas à saúde. Também foi um momento de

cessidade de refletir sobre o tema e buscar um esclarecimento para avançar na construção epistemológica que adotamos. (TESTA, 1997) Operacionalmente essas se identificam ao longo de todo o processo de construção da dissertação que dá origem a esta produção.

3 Fundação de Amparo à Pesquisa do Estado de São Paulo

4 Centro Latino-Americano e do Caribe de Informação em Ciências Sociais

5 Conselho Nacional de Desenvolvimento Científico e Tecnológico. 
aproximação dos conceitos da Filosofia Política - um importante subsídio para a compreensão das nuances que envolvem a questão do planejamento na área da saúde.

Após identificar os periódicos potenciais, foram levantados os artigos que tratam sobre o tema do planejamento em saúde, no recorte temporal do estudo, 1990-2010, o que constituiu a segunda etapa do estudo. Utilizamos, para isto, como descritores ou palavras-chave, as expressões "planejamento", "planejamento em saúde", "planejamento estratégico situacional" e "planejamento participativo em saúde".

Os artigos selecionados a partir destes descritores foram agrupados em uma pasta de documentos no computador e gravados em pastas específicas, por período, em meio eletrônico. Estes artigos também foram utilizados para a confirmação dos periódicos de circulação nacional pesquisados; a identificação dos autores; e a filiação institucional. Cada periódico identificado e confirmado foi pesquisado com uma busca no mesmo endereço eletrônico, por número publicado, identificando os artigos registrados a partir dos descritores referidos acima.

Identificados os autores, procedemos a uma nova pesquisa nesse endereço eletrônico (www.scielo.br) com os nomes selecionados, agrupando suas produções em pastas no computador, em disquete e cd-rom. Após este momento, cruzamos as diversas pastas selecionadas para excluir os artigos que se repetiam, procedendo, assim, para o primeiro movimento de seleção dos artigos que fariam parte do estudo, o que configurou a terceira etapa do estudo.

A segunda parada caracterizou-se como o momento das reflexões teóricas sobre a dialética como linha de pensamento e sua tênue relação com as demais linhas de pensamento nas Ciências Sociais e com a Saúde, onde esclarecemos a verdade sobre o método que escolhemos para trabalhar os dados, entendendo-o na sua quase completude. Esta parada teve sua importância para a determinação do olhar sobre o material bibliográfico encontrado e norteou a construção das primeiras matrizes teóricas que desenvolvemos para tratá-los.

Fizemos a leitura dos resumos dos artigos encontrados em cada revista para definirmos quais periódicos e artigos fariam definitivamente 
parte do estudo, o que se constituiu na quarta etapa metodológica. Esses artigos foram identificados, num primeiro momento, pelo ano da sua publicação, seguido do número correspondente à sua posição cronológica.

Na quinta etapa metodológica, procedemos à leitura sistemática dos artigos selecionados, ordenando e classificando o seu conteúdo, considerando autores, filiação institucional, identificação dos períodos da produção, seus respectivos objetos de análise, descritores, concepções teóricas, concepções metodológicas e temas abordados, com vista a responder aos questionamentos levantados no momento da problematização do objeto. Procuramos articular a síntese dos artigos com os livros produzidos na área de planejamento e gestão em saúde para compor a análise.

Todas as informações obtidas foram organizadas em um quadro analítico teórico, sendo que neste primeiro momento classificatório, procuramos realizar uma análise cuidadosa do material escrito com o intuito de se identificar os descritores, os objetos de análise e os tipos de estudo a partir dos signos linguísticos e ideológicos ${ }^{6}$ que lhes dão sentido. Para isto, nos alicerçamos em Minayo e Deslandes (2002), que resgata o instante hermenêutico como um processo no qual provisoriamente, e apenas para fins analíticos, se toma um material de representação social como um conjunto separado, a ser tecnicamente trabalhado.

Vários são os cuidados que Minayo e Deslandes (2002) nos orientam ter neste momento da análise, principalmente os cuidados relativos às regras metodológicas fundamentais da análise dos signos, se entendidos como temas: não separar a ideologia da sua realidade material; não dissociá-la de suas formas concretas de comunicação; e não dissociar a comunicação de suas formas e de sua base material.

Significa dizer que um instante hermenêutico inicial requer de nós aprofundamento sobre o significado das expressões para extrair o sentido que dará origem às estruturas de relevância do texto, ou seja, aquelas que comunicam de forma concreta o significado ideológico e material do que se quer dizer. As estruturas de relevância caracterizam os núcleos de sentido,

6 Signos linguísticos e ideológicos, numa compreensão adotada por Gadamer, citado por Minayo (2008) e re-significada por nós, neste trabalho, dizem respeito às formas de apresentação do conteúdo de um material científico, sendo-lhes conferida uma representação semântica polissêmica, de compreensão simbólica contextual - um encontro da retórica com a práxis. 
que conformam, por sua vez, as categorias analíticas que o estudo deve revelar.

Neste sentido, avançamos para a compreensão dos aspectos teórico-conceituais e metodológicos apresentados pelos livros e artigos selecionados no estudo, identificando, por meio da leitura exaustiva e repetitiva do seu conteúdo, as estruturas de relevância e as ideias centrais, cujas compilações nos levaram a encontrar as concepções teóricas e metodológicas do Planejamento em Saúde no Brasil no campo da Saúde Coletiva.

Este segundo momento classificatório revelou o primeiro ponto de inflexão hermenêutica e sua aproximação com a dialética: a definição das estruturas de relevância a partir da leitura do material escrito nos conduziu a realizar sínteses conceituais - uma construção, que, segundo Minayo e Deslandes (2002), caracteriza o encontro com os dados para a busca do sentido da totalidade histórica e das relações essenciais.

A terceira parada foi o momento da nossa descoberta sobre o poli-verso ${ }^{7}$ quantitativo-qualitativo das Ciências Sociais aplicadas à Saúde. Um instante de conflitos, pois se revelou durante o tratamento do material escrito no instante hermenêutico-dialético. Ora, se estávamos diante de uma perspectiva qualitativa e tínhamos que lançar mão de artifícios quantitativos para organizar os dados obtidos com a ordenação e a classificação, paradoxalmente fugíamos da centralidade qualitativa, ou seja, estávamos diante de uma possibilidade de "triangulação metodológica".

Este importante momento de reflexão nos permitiu construir alguns quadros analíticos complementares para identificar quantitativamente o tema quanto ao número de artigos publicados por periódico no período; número de artigos por tipo de estudo; relação artigos publicados/instituições responsáveis/pesquisadores envolvidos; hierarquização dos autores referenciados; e, por fim, a sistematização das temáticas abordadas nos

7 Poli-verso dá a ideia de pluralidade sobre a concepção de uni-verso. (BAREMBLIT, 2002)

8 Momento em que, por força da situação, o pesquisador se vê obrigado a lançar mão de elementos metodológicos diversos à perspectiva que está adotando, com vistas a explicar um fenômeno. Podemos caracterizar este momento como uma estratégia de pesquisa qualitativa que traga no seu bojo elementos da pesquisa quantitativa. Em outras palavras, seria o que Deslandes e Assis (2002) identificam como modelos de articulação quali-quanti, numa triangulação metodológica desejável e possivel. 
artigos selecionados com seus respectivos autores (Ver anexo no fim do livro).

Para serem determinadas as estruturas de relevância do texto, teríamos, a priori, a necessidade de fazer uma leitura transversal, cruzando os elementos individuais de cada artigo para levantar os temas relevantes que, se conformando como variáveis categóricas, contribuiriam para o próximo momento da análise - terceiro momento classificatório -, o refinamento da classificação, que se constitui num processo de aprofundamento da análise cujo objetivo principal é identificar a relevância de algum tema, que, uma vez determinado, permita refazer e refinar o movimento classificatório. (MINAYO; DESLANDES, 2002)

Este momento do trabalho procurou, portanto, uma aproximação ao que explicita a autora em epígrafe no que diz respeito ao aprofundamento classificatório, pois foi através dele que organizamos as "unidades de significação" dos artigos, cujas combinações revelaram as pré-categorias de análise, aqui denominados como "configurações", para avançar às categorias analíticas do tema Planejamento em Saúde no Brasil no campo da Saúde Coletiva. Foram identificadas nove configurações teórico-metodológicas (pré-categorias), cujas discussões apontaram para a validação do pressuposto teórico.

Partimos, então, para uma releitura dos textos contidos nos livros e artigos científicos para buscar um refinamento temático, já que as concepções apontavam para diversos temas. Esta ação nos possibilitou avançar para o detalhamento das dimensões de análise, traduzidas como categorias analíticas, tendo como categoria central: "Planejamento como dispositivo para garantir acesso aos serviços de saúde”, e duas categorias específicas: "Poder enquanto capacidade de manter ou transformar a realidade"; e "Sujeito e práxis". Estas categorias são detalhadas no corpo da presente produção.

Por fim, identificamos as concepções teóricas acerca do planejamento em saúde e estabelecemos um movimento de aproximação entre essas concepções e as categorias analíticas do estudo com a discussão da construção histórico-social do planejamento em saúde na América Latina e Brasil; o planejamento, as configurações e tendências no sistema e serviços 
de saúde; e os modelos teóricos analíticos para o acesso aos serviços de saúde, poder e sujeito social. Configurou-se, portanto, no momento da análise final dos dados - fruto do confronto de ideias entre os diferentes autores, os artigos e livros selecionados - num novo exercício hermenêutico-dialético, no qual procuramos responder as indagações, alcançar a totalidade, ainda que parcial, do pressuposto teórico, dando uma contribuição a mais para a compreensão histórica do planejamento no campo da Saúde Coletiva.

\section{REFERÊNCIAS}

BAREMBLIT, G. Compêndio de análise institucional e outras correntes: teoria e prática. 5. ed. Belo Horizonte, MG: Instituto Félix Guatarri, 2002.

CAMPOS, R. T. O. O planejamento em saúde sob o foco da hermenêutica. Ci. Saúde Col., Rio de Janeiro, v. 6, n.1, p.197-207, 2001.

DESLANDES, S. F.; ASSIS, S. G. A. Abordagens qualitativa e quantitativa: o diálogo das diferenças. In: MINAYO, M. C.; DESLANDES, S. F. Caminhos do pensamento: epistemologia e método. Rio de Janeiro: Fiocruz, 2002. p. 195-226.

FERRATER-MORA. Dicionário de filosofia. México: Atlante, 1941.

GADAMER, H. G. Verdade e método I: traços fundamentais de uma hermenêutica filosófica. 6. ed. Tradução de Flavio Paulo Meurer e Enio Paulo Giachini. Petrópolis-RJ: Vozes; Bragança paulista-SP: Editora Universitária São Francisco, 2004.

HABERMAS, J. Consciência moral e agir comunicativo. Tradução de Guido A. de Almeida. Rio de Janeiro: Tempo Brasileiro, 1989.

HOUAISS, A. Dicionário Houaiss de língua portuguesa. Rio de Janeiro: Objetiva, 2001.

MINAYO, M. C. S. O desafio do conhecimento: pesquisa qualitativa em saúde. 8. ed. São Paulo: Hucitec; Rio de Janeiro: Abrasco, 2004.

MINAYO, M. C.; DESLANDES, S. F. (Org.). Caminhos do pensamento: epistemologia e método. Rio de Janeiro: Fiocruz, 2002.

TANCREDI, F. B.; BARRIOS, S. R. L.; FERREIRA, J. H. G. Planejamento em Saúde. Saúde E Cidadania, v. 2, p. 5-13, 1998.

TEIXEIRA, C. F. O futuro da prevenção. Salvador: Casa da Qualidade Editora, 2001.

TESTA, M. Saber em salud: la construcción del conocimiento. Buenos Aires: Lugar Editorial, 1997. 


\title{
CAPÍTULO 2
}

\section{Planificação em saúde na América Latina: uma construção histórico- social}

\author{
Washington Luiz Abreu de Jesus \\ Marluce Maria Araújo Assis \\ Chaider Gonçalves Andrade \\ Sisse Figueredo de Santana
}

\begin{abstract}
[...] o planejamento é entendido enquanto instrumento para o desenvolvimento, e desenvolvimento significa crescimento do produto nacional, aceleração do ritmo deste crescimento. Desenvolvimento significa industrialização, modernização, e a racionalidade do cálculo econômico e do planejamento que as acompanha [...]. Giovanella, 1991.
\end{abstract}

\section{INTRODUÇÃO}

Da economia à política, do desenvolvimento econômico com base no livre mercado ao controle estatal da economia, do autoritarismo à democracia, a inserção do planejamento na América Latina se dá a partir da necessidade de uma maior intervenção do Estado em setores da sociedade para garantir o desenvolvimento econômico e, por conseguinte, os direitos sociais. (GIOVANELLA, 1991)

O planejamento na América Latina se desenvolve sob a ótica desenvolvimentista, uma alternativa ao isolamento imposto pela depressão econômica e pela Segunda Guerra Mundial, onde os países passaram a lutar por uma nova estratégia de desenvolvimento nacional (FRIEDEN, 2008), incentivados pela criação de alguns organismos internacionais, a exemplo 
da Organização Mundial de Saúde - $\mathrm{OMS}^{1}$ e as agências internacionais especializadas, como a Organização das Nações Unidas - ONU e o Fundo das Nações Unidas para a Infância (UNICEF). (MATTOS, 2001)

Na década de 1960, mais especificamente em 1965, foi desenvolvida, por um conjunto de autores latino-americanos ${ }^{2}$, a Publicação Científica $n^{\circ}$ 111 da Organização Pan-americana de Saúde (OPAS) com o título Programação em Saúde, problemas conceituais e metodológicos. Esse documento tinha como propósito a aplicação de princípios e métodos de planificação econômica para uma área social como a saúde e surgiu num momento favorável, que se caracterizava pela concomitância histórica do movimento da Aliança para o Progresso da América Latina, um instante de fomento do Banco Mundial para viabilizar os mercados latino-americanos, haja vista o estabelecimento do modelo econômico capitalista. (TESTA, 2004)

Como produto principal, desenvolveu-se o Método CENDES/OPS, construído pelo Centro de Estudos para o Desenvolvimento (CENDES) da Universidade Central da Venezuela, em conjunto com a Organização Pan-americana de Saúde (OPAS), que propunha a utilização ótima de recursos e instrumentos disponíveis por cada governo através de um processo de definição de prioridades, pautado no diagnóstico exaustivo, na análise de custos e de impacto econômico, de modo a racionalizar a utilização desses à adequada programação em saúde.

Teixeira $(2001,2010)$ afirma que o método CENDES/OPS propunha a construção de indicadores para diagnóstico em saúde com o levantamento e sistematização de variáveis demográficas, epidemiológicas e sociais, num enfoque descritivo, marcado pelo viés da planificação econômica, operando o cálculo da eficiência, da definição de prioridades, da combinação de recursos e do estabelecimento do prognóstico como elemento importante na determinação dos elementos constitutivos do planejamento.

1 A OMS é a agência especializada das Nações Unidas para a saúde. Concebida para oferecer cooperação técnica entre os países-membros, ela se engaja em um grande número de iniciativas de enfrentamento de problemas de saúde, bem como de iniciativas voltadas ao aprimoramento dos sistemas de saúde. (MATTOS, 2001)

2 Jorge Ahumada, Alfredo Arreaza Guzmán, Hernán Duran, Mario Pizzi, Eduardo Sarué e Mario Testa. 
A autora destaca que, apesar das limitações apontadas, os pressupostos do método continuam válidos até os dias atuais, ainda mais quando se trata da questão da programação da oferta de serviços, tendo como objetivo central a racionalização de recursos escassos. Tais pressupostos podem ser verificados nos critérios de priorização dos problemas de estado de saúde da população³ ${ }^{3}$ utilizados na formulação de planos de saúde, e parâmetros da Programação Pactuada e Integrada (PPI), proposta pelo Ministério da Saúde do Brasil.

Em 1975, o Centro Pan-americano de Planejamento em Saúde (CPPS) ancorado na crítica ao planejamento normativo estabelecido pelo método CENDES/OPS, propõe a valorização dos aspectos políticos e a incorporação de aspectos sociais no conteúdo da planificação em saúde. É lançado o documento intitulado Formulación de políticas de salud, que apresenta um esquema processual para a formulação de políticas de saúde a partir de uma "imagem-objetivo" construída com a identificação dos problemas de saúde da população e culminando com a formalização dessas políticas por meio de normas, decretos, leis, etc. $O$ destaque é que a proposta do CPPS avança na construção de um olhar sobre o sistema de saúde, compreendido como unidade complexa, organizada em níveis [técnico-operacional, técnico-normativo e político-administrativo] e expresso pelos componentes do sistema (gestão, financiamento, organização dos serviços, infraestrutura de recursos humanos, físicos e materiais). (TEIXEIRA, 2010)

Como produtos das reflexões críticas sobre a planificação na década de 1980, surgem três vertentes principais que conformam o Planejamento Estratégico aplicado à Saúde: o Planejamento Estratégico Situacional (PES), de Carlos Matus (economista chileno), o Pensamento Estratégico, de Mário Testa (sanitarista argentino) e o Enfoque Estratégico da Planificação em Saúde, desenvolvido na Escola de Medellín - Colômbia.

A primeira caracteriza-se pela discussão sobre os atores sociais em situação de governo, suas relações, a identificação de problemas e sua tipificação, o estudo do cenário em momentos de planejamento - explicativo, normativo, estratégico e o tático-operacional. Essa proposta está alicerça-

3 Magnitude, transcendência, vulnerabilidade e custos. 
da nas teorias da ação e da produção social, pois identifica que o "sujeito" do planejamento é partícipe de todo o processo e como tal deve compreender o espaço de produção social no qual está inserido e exercendo o seu fazer cotidianamente. (MATUS, 1993)

A segunda é caracterizada pela discussão acerca do poder enquanto relação de dominação e enquanto ideologia transformadora de uma sociedade. Apresenta uma tipologia para o poder, (sub)categorizando-o em poder técnico, político e administrativo, explicitando que seus recursos e circunstâncias conjunturais, temporais e sociais determinam a lógica e estratégia da programação no setor de saúde. (TESTA, 1995)

A terceira, por sua vez, tenta trazer para a discussão do planejamento em saúde o conceito de necessidades sociais através do critério das condições de vida, num arranjo sistêmico resultante da concepção funcionalista dos seus idealizadores. Em termos operacionais, essa perspectiva abrange a definição de subgrupos populacionais segundo critérios de acessibilidade geográfica aos serviços de saúde e de resolubilidade, isto é, do perfil de oferta dos serviços segundo a composição tecnológica. (GIOVANELLA, 1991)

\section{A CONSTRUÇÃO TEÓRICA DO PLANEJAMENTO EM SAÚDE NA AMÉRICA LATINA}

[...] as construções arbitrárias são mais ou menos rapidamente eliminadas pela competição histórica, ainda que por vezes consigam gozar de certa popularidade; ao passo que as construções que correspondem às exigências de um período histórico complexo e orgânico terminam sempre se impondo e prevalecendo, mesmo se atravessam muitas fases intermediárias nas quais a sua afirmação ocorre apenas em combinações mais ou menos bizarras e heteróclitas [...]. (GRAMSCI, 1991)

Discorrer sobre a construção teórica do Planejamento em Saúde na América Latina é um movimento que está assentado nos pilares da contradição e da historicidade. Revela uma transição de um momento puramente econômico para um momento ético-político de desenvolvimento dialético, de passagem do objetivo para o subjetivo, da necessidade para a liberdade, como diria Gramsci (1991). Para demonstrar a coerência histórica desse 
processo, nos inspiramos nas três obras fundamentais ${ }^{4}$ que demarcam as bases conceituais principais do Planejamento Estratégico aplicado à Saúde, precursoras teórico-metodológicas latino-americanas do Planejamento em Saúde no Brasil.

Nascido em 1931 no Chile, formado em Economia pela Universidade do Chile em 1955, Carlos Matus foi assessor do Ministro da Fazenda nesse país e Ministro da Economia do Governo de Salvador Allende, no período de 1965 a 1970. Preso político com o Golpe de Estado, intensificou suas críticas ao planejamento tradicional e concebeu o Planejamento Estratégico Situacional (PES).

Matus construiu a Fundação Altadir em 1988 na Venezuela, país onde viveu durante anos em exílio depois de saída da prisão em 1975 e foi autor de importantes obras, como Planificación de situaciones, Política, planificación y gobierno, Adeus Senhor Presidente e Estratégias Políticas: Chimpanzé, Maquiavel e Gandhi, entre outras, além de ter assessorado equipes de governo na área de planejamento, difundindo as ideias do PES em diversos países da América Latina.

Segundo Rivera (1992), na década de 1970, as críticas de Carlos Matus ao planejamento tradicional de governo, tomando como base a análise da planificação econômico-social, fundamentam-se no fato dele ter vivenciado o momento de implementação do processo de planificação desenvolvido pela CEPAL ${ }^{5}$. Critica o caráter eminentemente tecnicista do método CENDES/OPS, cuja concepção cartesiana, como fora idealizada, distanciava o governo da realidade estrutural da sociedade e produzia um enfadonho processo de planificação, praticamente impossível de ser operacionalizado dada a sua complexidade.

Para Matus (1993), o planejamento seria um processo técnico-político resultante do jogo de atores em interação, conflito, cooperação e através de alianças, constituindo-se num processo aberto e dialógico. Não é nada mais que tentar submeter o curso encadeado dos acontecimentos

4 Planejamento Estratégico Situacional (PES), de Carlos Matus (economista chileno); Pensamento Estratégico, de Mário Testa (sanitarista argentino) e Enfoque Estratégico da Planificação em Saúde, desenvolvido na Escola de Medellín - Colômbia.

5 Centro de Estudos para o Desenvolvimento Econômico e Social da América Latina 
cotidianos a um movimento coordenado de produção social mediado pelos conflitos inerentes ao processo de relações intersujeitos. Necessário se faz, então, promover a reconciliação do técnico com o político, o que, segundo sua concepção, não se contemplou no método cepalino.

Partindo das concepções e elementos de um governo em ação, o autor apresenta a proposta do PES trazendo para o campo do planejamento a dimensão política, o que se configurou na denominação de "estratégia". Este termo, segundo ele, se apresenta com múltiplos significados, podendo ser encarado como algo que é ao mesmo tempo importante e vulnerável. Adjetivos que expressam a ambiguidade do termo utilizado por Matus (1993) para definir sua proposta de planejamento. Trata-se de um modo de ganhar o jogo bem-estruturado, de ganhar o jogo dialético. E, como se trata de um jogo, está sujeito a vulnerabilidades. Um movimento, um encontro e uma luta na busca de objetivos. Um conjunto de ações táticas encadeadas em operações com vistas a alcançar a situação-objetivo, isto é, um fim.

Matus (1993) também parte do princípio que o planejamento é um método desenvolvido num cenário de governo ${ }^{6}$, no qual os atores sociais ${ }^{7}$ interagem e fazem parte da realidade a ser planejada. Nesse cenário de operacionalização do planejamento é que se assenta sobre o que ele denominou "Triângulo de Governo". O autor apresenta-nos então os elementos fundamentais da arte de governar, que exige do governante constante articulação entre seus vértices: o projeto de governo, a capacidade de governo e a governabilidade.

"Projeto de Governo" é o conteúdo propositivo dos projetos que a ação de um ator social se propõe realizar para alcançar seus objetivos. A "capacidade de governo" é definida por ele como o acervo de técnicas, métodos, destrezas, habilidades e experiências de um ator social individual, coletivo, institucional ou organizacional para conduzir um processo social a objetivos declarados. Por sua vez, a "governabilidade" é definida como a relação entre as variáveis que o ator controla e aquelas que ele não controla no processo de governo. (MATUS, 1993)

6 Conjunto de condições, circunstâncias, contexto no qual se desenvolve um plano.

7 Forças sociais e personalidades que controlam os centros de poder, podendo assumir dimensões individuais, coletivas e institucionais ou organizacionais. 
O equilíbrio entre o projeto de governo, a capacidade de governo e a governabilidade fazem parte de um conjunto de estratégias que caracterizariam o bom governo, que se utiliza destas para conhecer as aspirações do povo, exercendo seu poder em conformidade com leis e regras pré-estabelecidas, com justiça e concórdia, acomodando interesses em favor do bem comum. (MATUS, 1993)

Estabelecer o equilíbrio no jogo deve ser uma estratégia do governante, pois sem o devido equilíbrio não é possível conduzir processos políticos. O PES tem o objetivo de municiar os atores sociais em situação de governo para o enfrentamento da realidade estabelecida através de ações estratégicas delineadas a partir do reconhecimento da referida realidade, num cálculo interativo sobre o espaço real das possibilidades de ação criativa.

O ponto de partida para um planejamento eficaz, portanto, é a identificação precisa dos problemas a partir da interação dos atores sociais, enfrentando a sua realidade, diagnosticando as situações-problema e estabelecendo cálculos interativos com vistas à descoberta dos espaços reais de possibilidades de ação criativa no cenário no qual atua.

O PES representa uma tentativa de se instituir uma nova abordagem no contexto da planificação. O método proposto por Matus (1993) parte de uma análise pormenorizada da estrutura social da sociedade, identificando seus problemas e hierarquizando-os, de modo a se obter um conjunto de fluxogramas analíticos, com os quais é possível se fazer o diagnóstico situacional, se identificar nós críticos, se traçar estratégias e ações, calcular riscos e operacionalizar soluções.

Apesar de seu caráter estratégico, o que podemos verificar no PES é uma reprodução da complexidade operacional, o que não difere da proposta cepalina por ele criticada, apesar do avanço da incorporação do componente político, representado pelo governo-sujeito, isto é, pelos atores sociais institucionalizados.

Mário Testa, médico sanitarista argentino, formado pela Faculdade de Medicina da Universidade de Buenos Aires, trabalhou inicialmente como médico assistencialista e depois se dedicou a estudar os problemas do desenvolvimento no CENDES, onde ajudou a construir o Método 
CENDES/OPS. Foi funcionário da Organização Pan-americana da Saúde OPAS, nos Estados Unidos, e do CPPS, no Chile.

Regressando à Argentina em 1971, se tornou interventor e depois Diretor da Faculdade de Medicina da Universidade de Buenos Aires. Em 1976 saiu novamente do país, com o Golpe Militar, retornando somente após a redemocratização. Suas principais obras foram Pensar en salud, Pensamiento estratégico y lógica de programação, Estratégia y programación e Saber en salud.

Ele procura trazer uma discussão mais teórico-conceitual acerca do processo de planejamento, destacando o caso da saúde em vários momentos: política, estratégia, poder, sujeitos, cenário, programação, demanda, oferta, instrumentos, atividades, organização, mercado, diagnóstico, indicadores e tempo. Os quais, de certa forma, podem ser identificados como categorias de análise que o autor procura desenvolver para subsidiar a discussão acerca do planejamento aplicado ao setor de saúde.

Com o "Pensamento Estratégico", Testa (1995) busca construir uma análise sobre o planejamento, tomando como base uma avaliação do poder e sua relação com os diversos sujeitos nos diferentes momentos do diagnóstico situacional.

De fato, o autor expressa sua preocupação com o planejamento no que se refere à necessidade de se observar os elementos políticos, científicos e históricos da sociedade, sem perder de vista a dimensão econômica. Desenvolve seu trabalho num contexto de crítica ao Método CENDES/OPS, devido ao fato de ter participado da sua elaboração. Pôde perceber, com o passar dos anos, sua "falácia" enquanto método para a resolução dos problemas sociais, especificamente os da saúde.

O pensamento estratégico é um pensamento sobre as formas de uso do "poder", compreendido a partir da diferenciação entre a sua política de distribuição e a sua estratégia de implementação. Um dos pontos fundamentais refere-se à definição de atores sociais como sujeitos de uma ação e objetos do próprio pensamento estratégico, identificando para isso a constituição desses atores, num processo dinâmico de transformação histórica.

O poder é uma categoria que contém uma ação, manifestando-se de forma opaca na sociedade, representando o imperativo da força e da 
violência legitimados. O Estado, segundo Testa (1995), é mediador das relações de poder na sociedade, caracterizado pela existência de espaços de decisão, isto é, locais onde se organizam os recursos para a mediação dos conflitos e contradições institucionalizadas no contexto das expressões políticas das relações sociais.

Para Testa (1995) o espaço de atuação do poder é o Estado, se considerada a história dos países na atualidade. Neste contexto os sujeitos do poder atuam no Estado, seja na condição de participante ativo ou passivo, enquanto componente efetivo do Estado ou enquanto componente da sociedade organizada. 0 exame dos espaços de atuação dos sujeitos revela, segundo ele, que a correta operacionalização do planejamento depende prioritariamente das relações de poder que se estabelecem nos espaços institucionais.

O poder instituído somente se consolida em situações de "equilíbrio". Planejar para Testa significa construir relações de "equilíbrio" no universo do poder, sendo necessário, portanto, identificar o poder enquanto categoria de análise social, para conformar as suas diferentes facetas e formas de organização, nos espaços institucionais e sociais em que atuam os diversos sujeitos.

Testa (1995) apresenta as formas organizativas do poder como resultado das relações internas, do saber e da prática dos sujeitos, dos conhecimentos empíricos e científicos, das práticas hegemônicas, da dominação e da significação social das diferentes formas de poder, que são: o "poder político", estabelecido no movimento de equilíbrio de interesses da sociedade e sua conjuntura; o "poder técnico", estabelecido no modelo teórico interativo dos diversos tipos de conhecimento a serviço da sociedade; e do "poder administrativo", que se utiliza de recursos como a gestão, a organização e a normalização para se instituir.

O poder, portanto, segundo reflexões de Testa (1995), é categoria organizativa da sociedade, e se materializa na construção de um corpo instrumental, elemento do planejamento que chama de diagnóstico, o qual, por sua vez, no campo da saúde, deve atender aos propósitos de crescimento, mudança e legitimação. Estes diagnósticos (administrativo, estratégico e ideológico) refletem o estado de saúde da população e suas tendências, a organização dos serviços e do setor de saúde. 
O "diagnóstico administrativo" é caracterizado pela lógica da programação para o crescimento dos serviços de saúde e da produtividade. Utiliza-se da análise do estado de saúde e da epidemiologia para estabelecer os critérios de gravidade, de urgência e de emergência nas diferentes situações. Baseia-se na eficácia, na eficiência e na efetividade. 0 "diagnóstico estratégico" é caracterizado com o propósito de estabelecer as mudanças. Alicerça-se na lógica da programação e no pensamento estratégico, tendo como mote principal a busca do equilíbrio dinâmico entre o sujeito/ ator social e a sociedade. O "diagnóstico ideológico" é caracterizado pela busca da legitimidade das propostas em saúde, a partir da concordância entre uma ideologia dominante ou hegemônica e uma ideologia alternativa, pautando-se na consciência sanitária, nos âmbitos individual, corporativo e de classe, e nas dimensões biológica, sanitarista, ecológica e social.

Nesse contexto, Testa (1995) trabalha também a consciência sanitária como elemento importante na construção das ideologias dominante e dominada, utilizando-se destas subcategorias para identificar as relações existentes entre os sujeitos/atores sociais e quantificar as dimensões nos diferentes âmbitos, estabelecendo as respostas sociais e, por conseguinte, consciência social.

No final da década de 1980, mais especificamente no ano de 1987, é desenvolvido, à luz da Declaração de Alma Ata (1978), o documento Saúde para todos no ano 2000: implicações para a planificação e administração dos sistemas de saúde, de autoria de J. J. Barrenechea e Uribe E. T. e outros, voltado para a orientação política de construção da promoção da saúde, com enfoque sobre a educação e ações voltadas para a consolidação da Atenção Primária em Saúde - o Enfoque Estratégico (Proposta de Medellín). (GIOVANELLA, 1991)

O planejamento, na perspectiva do "enfoque estratégico" é um processo complexo que influencia na mudança a partir de uma determinada força social. Pensar o futuro é uma ação que exige o conhecimento de uma teoria política. Há consciência da existência de interesses conflitivos no processo. Seus autores admitem a "complexidade" do sistema como parte integrante do âmbito social. Também admitem a fragmentação e a existência de variáveis que estão fora do controle dos atores envolvidos no 
processo de planejar. Concebem que o tratamento do futuro é um jogo de incertezas, no final existem forças contrárias e demandam constante processo de negociação. (GIOVANELLA, 1991)

\section{RECONSTITUIÇÕES TEÓRICO-METODOLÓGICAS DO PLANEJAMENTO EM SAÚDE NO CENÁRIO BRASILEIRO}

O debate acerca do planejamento em saúde no Brasil é contemporâneo ao debate da redemocratização do país, à constituição do SUS e ao desenvolvimento da área da Saúde Coletiva. Em que pesem os estudos desenvolvidos na década de 1970, efetivamente, só a partir da década de 1980 é que o tema passa a ter a devida importância no que se refere à construção de um referencial.

Ora, urgia a necessidade de preparar o país para um novo momento político, abrindo possibilidades para construir as bases teórico-metodológicas para sustentar aquele novo momento. A discussão desenvolvida pelos teóricos internacionais serviu de subsídio para o desenvolvimento das primeiras produções brasileiras, cujo objetivo era trabalhar com elementos que possibilitassem a implementação das políticas de saúde com base nos fundamentos doutrinários da Constituição Federal de 1988. O que antes era privilégio de um número reduzido de sujeitos, escondidos no aparato burocrático do Estado, agora seria uma possibilidade ao alcance daquele que se dispusesse a colaborar com o ideal libertário da Reforma Sanitária na busca de um sistema de saúde mais digno e equânime para a população.

A resposta da academia a essa necessidade social foi edificada, principalmente em alguns locus de produção acadêmica, a exemplo da Escola Nacional de Saúde Pública (ENSP), Universidade de São Paulo (USP), Universidade Federal da Bahia (UFBA) e Universidade Estadual de Campinas (UNICAMP), que adotaram a perspectiva do Planejamento Estratégico aplicado à Saúde, com destaque à trilogia matusiana ${ }^{8}$, como matrizes conceituais e

8 Termo utilizado por Artmann (1993), representando o Planejamento Estratégico Situacional (PES), o Planejamento por Projeto Orientado por Objetivos (ZOOP) e o Método Altadir de Planificação Popular (MAPP) 
realizaram trabalhos de construção de novos modelos operacionais para o planejamento de saúde.

Nessa perspectiva, os trabalhos científicos ${ }^{9}$ desenvolvidos por Rivera (1992, 1996, 2003, 2010); Rivera e Artmann (1999); Artmann (1993); Artmann e Azevedo (1997); Artmann e Rivera (2003); Paim (1981, 1989, 1993, 2002, 2003, 2006); Teixeira (1993, 1994, 1996, 1997, 1998, 1999, 2001, 2003 , 2009, 2010); Schraiber (1993); Schraiber e outros (1999); Mendes (1999); Chorny (1993, 1996); Merhy (1987, 1993, 1995, 1997, 1999, 2004); G. Campos (1992, 1994, 2000); Cecílio (1991, 1997); Gallo (1995); R. Campos (2000, 2001, 2003); Vilas Bôas (2006); dentre outros, sujeitos importantes na discussão do planejamento no campo da Saúde Coletiva, vem influenciando toda a construção teórico-metodológica da área a partir do final da década de 1980 até os dias atuais.

O planejamento assume, então, uma nova conformação, sendo necessariamente um instrumento, ou tecnologia, ou dispositivo capaz de promover mudanças histórico-estruturais no ambiente social, através da instituição de processos de promoção da qualidade de vida de sujeitos e coletivos. (CAMPOS, R., 2001; VILAS BOAS, 2006)

Rivera (1996) busca estudar o planejamento em saúde, tomando como eixo orientador os trabalhos de Carlos Matus e Mário Testa, e de modo crítico e reflexivo discorre sobre a trajetória histórica da planificação na América Latina, que vai desde o enfoque normativo ao enfoque estratégico e analisa a lógica dos marcos doutrinários desta tendência, polemizando inclusive sobre esta polaridade.

O enfoque normativo, segundo o autor, supõe que objeto e sujeito são independentes, sendo que o último é posto de fora ou acima da realidade; orienta-se pela verdade objetiva e fundamenta-se no diagnóstico; dá-se através de modelos analíticos de causalidade baseada na realidade objetiva, apontando um único caminho para resolução dos problemas. 0 enfoque estratégico, por sua vez, coloca o sujeito dentro da realidade, coexistindo com outros atores; a realidade é processual e a resolução dos

9 Os autores selecionados refletem o "estado da arte" utilizado na produção do estudo que deu origem a este livro. Salientamos que se trata de um recorte que não tem a intenção de apresentar uma totalidade absoluta das formulações da área, já que se trata de uma área em constante transformação, movida pelo cotidiano e pelas iniciativas do sistema e dos serviços de saúde. 
problemas pressupõe um cálculo estratégico interativo, isto é, que admite várias possibilidades de conduta. (RIVERA, 1992)

Rivera (1992) discute também os desdobramentos das propostas desenvolvidas por Mário Testa e Carlos Matus na América Latina com impacto sobre o Brasil. Analisa as proposições do documento Saúde Para Todos no Ano 2000, sobre a programação local de saúde, a formação dos distritos sanitários ${ }^{10}$ e o enfoque estratégico, lançando as bases conceituais que apontam para um modelo teórico de programação local e regional, em cujo espaço particular se encontram os grupos sociais e suas condições objetivas de vida. A proposta tem uma articulação com o desenvolvimento da proposta do Sistema Unificado e Descentralizado de Saúde (SUDS), instituído no Brasil no final da década de oitenta enquanto modelo de reorganização da assistência à saúde no país, num processo de transição para o Sistema Único de Saúde (SUS).

Nesse trabalho, Rivera aproveita conceitos desenvolvidos por Chorny (1987) na definição dos requisitos da programação de sistemas locorregionais de saúde na lógica dos distritos sanitários. A programação se define como um espaço do planejamento, um momento tático do programa estratégico que conforma o plano, devendo comportar a participação efetiva da população. Um modelo de programação baseado nas necessidades de saúde, observando os fatores de risco (sociais, políticos, demográficos, epidemiológicos, etc.).

A produção de Rivera (1992, 1996, 2003), Rivera e Artmann (1999, 2010), por fim, traz uma abordagem a partir da perspectiva alinhada com os pensamentos de Jürgen Habermas (1989), mostrando o planejamento sob a ótica do agir comunicativo, que propõe um consenso entre as diferentes técnicas e modelos operacionais. Propõe um novo elemento no contexto da planificação - a comunicação, e discute a Organização Comunicante enquanto espaço de operacionalização do planejamento comunicativo, uma intensificação do momento explicativo do PES, transformado a partir de novos elementos como a escuta, a cultura, a liderança, a negociação, o diálogo e o resgate da subjetividade. Além do mais, oferecem diversas

10 Distrito Sanitário é a unidade mais periférica da administração sanitária, que detém responsabilidades e poder decisório ante a política local de saúde. (MENDES, 1999) 
abordagens, tais quais: a incorporação de um enfoque de planejamento/ gestão estratégica(o) de hospitais, as redes de conversação, tudo isso com a influência da escola da organização que aprende e da filosofia da linguagem aplicada à gestão organizacional.

Edmundo Gallo (1995), também alicerçado no contexto da ação comunicativa, desenvolve, no início da década de noventa, um trabalho que discute a dimensão da práxis enquanto articulação entre teoria e prática, atividade emancipadora do homem e da sociedade; como elemento importante do planejamento em saúde, cuja diferenciação histórica e racionalidade teleológica contribuem para a racionalização da ação estratégico-instrumental e para a transformação da sociedade.

Chorny $(1993,1996)$, com seus trabalhos desenvolvidos no início da década de noventa, discute as novas ideias do planejamento em saúde a partir de novas roupagens. Para ele, o propósito do planejamento em saúde, assim como o da gestão dos serviços, é a melhoria das condições de saúde das populações ou grupos aos quais os programas e serviços se dirigem. O principal objetivo do planejamento em saúde é a própria saúde, considerada na sua complexidade, tanto no que se refere a curto quanto em longo prazo, observando-se o presente e o futuro. Seus trabalhos subsidiaram o desenvolvimento de uma corrente que defende o "planejamento como um meio de intervenção em ambientes complexos", identificada por R. Campos (2003).

Artmann (1993), Artmann e Azevedo (1997), Artmann e Rivera (2003) discutem o Planejamento Estratégico Situacional a partir de uma análise da trilogia matusiana, adotando uma abordagem comunicativa para desenvolver uma proposta de intervenção para o nível local de saúde. Trouxe, no bojo dessa discussão, questionamentos acerca da inexistência de uma reflexão mais aprofundada sobre a cultura enquanto componente de viabilidade de uma intervenção planejada para o nível local de saúde, contribuindo para a reconstituição do pensamento planejador no campo da Saúde Coletiva por discutir não somente a cultura, mas os aspectos microeconômicos enquanto componentes da complexidade organizacional e como elementos de um modelo de Planejamento e Gestão Estratégica na perspectiva comunicativa. 
Importa destacar que os autores se apoiam na aplicação do PES no processamento de problemas transversais. No combate ao paradigma flexneriano da clínica, desenvolvem sistemas de microrregionalização solidária, como célula de um sistema regionalizado pautado na construção de sistemas integrados de saúde. (RIVERA; ARTMANN, 2010)

Mendes (2010), quando discute a organização dos sistemas e serviços de saúde, analisando historicamente a conformação do sistema de saúde brasileiro, principalmente a partir da década de 1970, explicita os modelos assistenciais implementados nesse contexto e apresenta a proposta dos distritos sanitários enquanto "micro-espaço de luta política entre atores sociais portadores de diferentes projetos, no qual se deve procurar a acumulação de capital político, poder, para construir viabilidade à situação-objetivo que se quer alcançar". (MENDES, 2010)

Diversos autores tomaram como base a produção de Mendes para discorrer sobre o assunto e estabelecer marcos conceituais para definir os rumos da assistência à saúde, o que configurou o movimento de programação anterior à implementação do SUS e posterior à sua regulamentação, com a Lei Orgânica da Saúde. A lógica dos distritos sanitários adaptada à realidade brasileira e a discussão da trajetória dos projetos hegemônico e contra-hegemônico, foi absorvida pelos sujeitos do planejamento nas dimensões técnica, política e administrativa, culminando em diversas propostas operacionais.

Mais recentemente, Mendes (2010) traz outra discussão que agrega ao debate sobre os desafios do planejamento no SUS: a das redes de atenção à saúde. Segundo Mendes (2010), existe uma crise no país, tanto no setor público, tanto no privado, que se explica pela incoerência entre uma situação de saúde com predomínio relativo de situações crônicas e uma resposta social através de sistemas fragmentados e voltados para as condições agudas e as agudizações das condições crônicas. E a solução para essa crise está na recomposição efetuada entre a situação de tripla carga de doenças com a resposta social estruturada em sistemas integrados de saúde: as redes de atenção à saúde.

Schraiber, Duzzi e Sala (1999), triangulando com os conceitos da epidemiologia clássica e da administração, não apresentou modelo opera- 
cional que rompesse com os paradigmas instituídos, propondo consensos entre as técnicas e os modelos operacionais existentes. No entanto, apresentou a ação programática como um dispositivo de organização tecnológica do trabalho dotado de caráter crítico e de flexibilidade técnica e política.

Ainda no final da década de oitenta e início da década de noventa, Schraiber estabeleceu a re-significação das bases conceituais da Ação Programática em Saúde enquanto modelo teórico para organização de serviços de assistência à saúde no Brasil. Desenvolveu, em conjunto com Mendes Gonçalves e Baptistella Nemes, as seis teses sobre a ação programática em saúde, evidenciando que o objeto do planejamento explicitado em sua proposta está centrado na Epidemiologia e na Saúde Pública enquanto ciências que norteiam a padronização e organização do trabalho na busca de um processo de construção (des) burocratizado, desenvolvido de forma coletiva, porém racional, trabalhando as questões relacionadas à escassez de recursos, à dimensão econômica e à ideologia política.

Paim (1981), no início da década de 1980, discute a crise do planejamento autoritário em saúde. Num resgate histórico minucioso, detalha a evolução do pensamento da planificação como instrumento de economia e política, datado da década de trinta, quando do desenvolvimento de uma política econômica nacionalista. Revela que a introdução do planejamento em saúde no setor governamental de saúde brasileiro data de 1974, pelo recém instituído Ministério da Saúde, e mostra sua ineficácia dado o autoritarismo com que fora implantado, centrado na racionalidade tecnocrática dos adeptos da modernização conservadora, e sua desarticulação com os trabalhadores de saúde e os setores populares.

Paim $^{19-20}$ desenvolveu, ao longo das décadas de 1980 e 1990, algumas reflexões resultantes do trabalho de implantação da proposta dos Sistemas Locais de Saúde (SILOS) no processo da descentralização e da implantação do Sistema Unificado e Descentralizado de Saúde (SUDS) na Bahia. 0 autor também propõe um redesenho da proposta "Saúde Para Todos no Ano 2000" (SPT-2000), um planejamento voltado para a prática, levando em consideração o processo de trabalho na ponta do sistema, isto é, nos serviços de saúde. 
Esse autor, discutindo as bases da proposta tecno-assistencial da Vigilância da Saúde, apoia-se na epidemiologia e na discussão sobre as políticas públicas para dialogar sobre os modos de organizar os serviços para responder as necessidades de saúde da população. Mais recentemente vem buscando compreender a área de Política, Planejamento e Gestão em Saúde (PP\&G) com reflexões sobre seu "estado da arte", seguindo uma tendência dos últimos dez anos (PAIM, 2002, 2003; PAIM; TEIXEIRA, 2003)

Teixeira $(1993,1994)$ desenvolve suas ideias no cenário dos sistemas locais de saúde, buscando uma aproximação entre teoria e prática de fato exequível, isto é, buscou em seus trabalhos apresentar subsídios concretos para operacionalizar um modelo de planejamento compreensível aos sujeitos da prática social. Trabalha com a teoria dos distritos sanitários desenvolvida em conjunto com Mendes, Araújo e Cardoso, apresentando os conceitos-chave da proposta de distritalização em saúde para o Brasil e estabelecendo passos metodológicos para o planejamento e programação local desses loci - os espaços de concretização das ações de saúde.

Essa autora afirma ainda que os distritos sanitários são espaços de reorientação gerencial e operativa do sistema de saúde. O planejamento e programação local são vistos como um conjunto de processos sociais e históricos, instrumentos de transformação da práxis, entendida como prática social transformadora. Nesse contexto, a proposta do Planejamento e Programação para os Sistemas Locais de Saúde (PPLS) representa um dos marcos conceituais mais importantes do vínculo existente entre a teoria do planejamento e o distrito sanitário, conferindo veracidade à afirmação de que o plano de mudança precisa ser de fácil acesso aos sujeitos da prática social. (TEIXEIRA, 1994, 1996, 1997, 1999)

Merhy, Campos e Cecílio são sujeitos que desenvolveram seus trabalhos sobre os temas transversais da área em questão, trazendo à centralidade a discussão do sujeito, seja enquanto gestor, trabalhador ou usuário do sistema e dos serviços de saúde. A dimensão conceitual apresentada por esses autores, principalmente Merhy e Campos, resguardando-se suas particularidades, se caracteriza por discussões que vão desde o aprofundamento ideológico das questões relacionais ao sistema e aos serviços de 
saúde - a micropolítica - até uma discussão macropolítica dos processos de gestão institucional e dos modelos tecno-assistenciais em saúde.

Diferentemente de Rivera, que também trabalha com a subjetividade, a discussão sobre o sujeito defendida por Merhy (1987, 1993, 1995, $1997,1999)$ se dá na dimensão do trabalho vivo em ato ${ }^{11}$, seja ele técnico, político, administrativo ou social. Portanto, o elemento central do planejamento em saúde não é apenas um método, um espaço ou lócus, um contexto, um processo. É o sujeito/ator social inserido num dado contexto histórico e envolvido com o processo de transformação da sociedade a partir do valor do seu trabalho e seu reconhecimento a partir dele. De certa forma, o autor apresenta uma concordância com G. Campos (1992, 1994, 2000) no que se refere a isto, se considerarmos a produção selecionada nesta análise.

Merhy (1995) apresenta o planejamento como uma tecnologia a serviço da gestão, sendo um conjunto de instrumentos que possibilitam imprimir uma maior eficácia na busca da otimização dos sistemas e serviços de saúde. A gestão política torna o campo do planejamento um cenário de disputas determinado pelas intencionalidades dos diversos sujeitos sociais, que, no exercício do poder, e, dependendo de suas historicidades, impõem os instrumentos e determinam a racionalidade com que os projetos devem ser instituídos.

Campos, Merhy e Nunes (1994) apresentam um "planejamento sem normas", trazendo elementos para repensar o planejamento e a administração sob diferentes ângulos, não se detendo a oferecer soluções prontas ou estabelecidas tecnicamente, mas a sugestionar formas de pensar e operar a saúde. Propõem, contudo, que o campo do planejamento e da administração seja balizado pela compreensão da história e da política, valorizando os conflitos existentes no jogo dos diferentes sujeitos sociais em ação. Planejar em saúde, então, é um processo construído a partir das necessidades socialmente apresentadas. 0 sujeito social deve ser dotado de instrumentos úteis à sua intervenção, ou seja, de armas para enfrentamento dos problemas historicamente constituídos.

11 O termo "trabalho vivo em ato" foi desenvolvido por Emerson Elias Merhy (1997) para denominar o trabalho em saúde, pela saúde e para a saúde. 
As construções teóricas de G. Campos (1992, 2000), particularmente, levaram-no a desenvolver, em 2000, o "Método para Análise e Co-gestão de Coletivos", cuja importância no campo do planejamento em saúde se dá pelo fato de estabelecer uma consistente discussão acerca da constituição dos sujeitos e dos coletivos numa sociedade democrática. Discute que o fortalecimento do sujeito somente é possível mediante uma democracia institucionalizada, ou seja, no momento em que as instituições/organizações se apresentem como espaços coletivos que produzam sujeitos com capacidade de análise e intervenção.

Além disso, G. Campos (2010), em sua discussão mais recente, nos trás a tensão entre a racionalidade gerencial dominante e o trabalho em saúde, valendo-se de conceitos da filosofia e da revisão de autores que estudaram o trabalho em saúde. Dessa forma, as práticas clínicas em saúde pública não funcionam mecanicamente e dependem de um sujeito mediador que reflita e tome decisões na maioria dos casos. Nesse sentido, o autor recomenda a adoção de modelo de gestão que possibilite e favoreça a combinação de autonomia profissional com responsabilidade sanitária.

Tomando a consideração de Matus (1993): "Quem planeja, governa”. Para governar, o sujeito deve estar fortalecido e com capacidade de analisar e intervir. A "co-produção de sujeitos e coletivos", proposta por R. Campos (2000), ecoa a afirmativa de Matus na medida em que identifica o planejamento como sendo um espaço de construção, de produção de cidadania, saúde e democracia. É um espaço de construcionismo (RIVERA; ARTMANN, 1999), de construtivismo social, de libertação.

Na discussão de G. Campos (2000) aparecem elementos importantes para a teoria do planejamento no campo da saúde já desenvolvidos por outros autores, ainda que não tenha sido essa sua intenção. Esse autor faz uma re-significação dos conceitos e teorias, conferindo-lhes nova interpretação. Ou seria melhor dizer, uma ampliação epistemológica. Apresenta a re-significação do trabalho; o poder e sua relação com os sujeitos na co-produção de necessidades; os dilemas da autonomia; a re-significação da práxis; a produção social da subjetividade e a co-gestão.

Cecílio, em 1994, desenvolveu um modelo operacional conjugando elementos do Planejamento Estratégico Situacional (PES) e o Planejamento 
Orientado por Objetivos (ZOPP) como produto de sua tese, e propôs uma redefinição do papel institucional de uma organização hospitalar pública, num processo de mudança orientado pelo instrumental do planejamento em saúde. Em 1997, o mesmo autor ampliou esse modelo, apresentando uma proposta tecnológica aplicável aos setores governamentais, identificando os atores responsáveis pelo plano, a situação desses atores na organização e desenhando estratégias operacionais para enfrentamento dos problemas, que, na pauta da gestão estratégica, definem a intitulada missão institucional. (CECílIO, 1997)

A contribuição de Cecílio, naquele momento histórico, preencheu uma lacuna importante da proposta unicampiana, trazendo a dimensão técnico-operativa dessa proposta para a pauta da discussão do planejamento, o que, até então, pelo menos diante daquilo que dispomos de material científico divulgado, não havia sido apresentado. Trazer uma tecnologia leve de planejamento aplicada ao setor governamental demonstra a preocupação do autor com o contexto macropolítico, explicitando a importância estratégica enquanto elemento gerencial para proporcionar mudanças.

\section{AS DIFERENTES CORRENTES DO PLANEJAMENTO NO CAMPO DA SAÚDE COLETIVA: BUSCA DE NOVAS TECNOLOGIAS PARA A GESTÃO DO SISTEMA E DOS SERVIÇOS DE SAÚDE}

Nesta seção, procuraremos fazer uma releitura dos trabalhos já publicados no campo da Saúde Coletiva que tratam dos modelos operacionais do planejamento em Saúde no âmbito do SUS. Aproveitaremos os textos produzidos por Merhy (1995), Rivera e Artmann (1999, 2010), G. Campos (2000) e Teixeira (2003), que discutem os modelos assistenciais numa perspectiva crítico-reflexiva, apontando os elementos constituintes dos diferentes modelos de planejamento adotados nesses contextos.

Acreditamos que este momento nos remete a uma aproximação entre teoria e prática, um instante hermenêutico que nos possibilita compreender de que forma o planejamento em saúde se operacionaliza no cotidiano do sistema de saúde e testificar a relação histórica do tema com a realidade brasileira e com os sujeitos do planejamento no lócus do sistema. 
Independente da vertente teórico-filosófica que os sustentem, os modelos aqui apresentados mostram a riqueza conceitual que o planejamento tem mostrado no curso do desenvolvimento e da consolidação do SUS no Brasil. Outrossim, o resgate desses trabalhos também nos possibilita verificar o aprofundamento prático da teoria do planejamento em saúde no país.

Merhy (1995), ao apresentar o planejamento como tecnologia para a gestão, discorreu inicialmente sobre os quatro caminhos para o planejamento em saúde no Brasil, alicerçados nos diferentes modelos tecno-assistenciais implementados no âmbito do SUS. Estas perspectivas apresentam como ponto comum o reconhecimento da existência de uma crise estrutural no setor de saúde e a necessidade de reforma nas práticas de saúde. Aparecem no cenário as várias relações de poder e o modo como este poder está distribuído nas diferentes propostas de modelos tecno-assistenciais que coexistem no Brasil. São eles: as Ações Programáticas em Saúde; o Agir Comunicativo em Saúde; a Vigilância da Saúde; e a Gestão Estratégica em Saúde - o modelo "Em Defesa da Vida". Dessa forma, para o autor, o entendimento da máquina conceitual construída por um pensador específico ou por um coletivo definido é um caminho interessante para a compreensão de problemas em certas circunstâncias, e se faz sentido para quem está em situação de gestão, portanto pode ser um elenco para se construir alternativas de ação.

Merhy (1995) mostra que o planejamento na "Ação Programática em Saúde" se concebe a partir da construção coletiva do conhecimento do processo saúde-doença, objeto de modelos tecnologicamente ordenados em serviços de saúde, que subordinam as ações individuais e coletivas a um projeto programático. Para o "Planejamento Comunicativo", é imprescindível a introdução do sujeito na esfera do planejamento. Surge a figura do ator social - sujeito - no processo de implementação de um modelo de planejamento.

A "Vigilância da Saúde", segundo o autor, incorpora em sua metodologia de planejamento elementos do Planejamento Estratégico Situacional (PES), partindo da identificação de riscos e necessidades de saúde em um dado território, de modo a utilizar as informações obtidas para confeccionar um planejamento pautado no conhecimento técnico, cuja 
ação é sobre os riscos potenciais à saúde. A "Gestão Estratégica" incorpora elementos do PES, do Pensamento Estratégico e da Análise Institucional, sendo apresentada como o resultado do uso de tecnologias a serviço dos sujeitos no processo de trabalho, numa articulação entre as diferentes arenas decisórias para a consolidação da natureza pública dos serviços de saúde. (MERHY, 1995)

Rivera e Artmann (1999) coadunam com as ideias de Merhy no que diz respeito às diferentes perspectivas de planejamento no âmbito dos modelos tecno-assistenciais do SUS. Quando analisa a corrente da "Vigilância da Saúde" destaca a busca de uma operacionalização prática dos conceitos do planejamento situacional dentro do contexto de um distrito sanitário, no sentido da eficiência e da eficácia sociais, equidade e democratização, ancorados no paradigma da promoção da saúde, numa visão mais sócio-ambiental do processo saúde-doença, o que de fato requer uma ação mais intersetorial.

Além disso, atualmente, Rivera e Artmann (2010) dialogam as contribuições de Mendes (2009) com essa corrente, no planejamento e montagem das redes de atenção à saúde. Dessa forma, Mendes (2009) nos traz a discussão do tema das redes de atenção à saúde, que é recente no Brasil, e não há experiências em escala, nem avaliações robustas. Porém, estudos de casos de experiências de redes de atenção à saúde indicam que elas, à semelhança do que ocorre em países desenvolvidos, podem ter impacto significativo nos níveis de saúde, com custos toleráveis pelo SUS.

A corrente da "Ação Programática em Saúde", na sua concepção, propõe a construção de um sistema de saúde programado pela Epidemiologia Social, alicerçada nas tecnologias de trabalho que integram as práticas médica e sanitária, num processo de programação.

Também traz considerações acerca da "Gestão Estratégica em Saúde", apresentando o método de planejamento desenvolvido a partir da concepção da tecnologia leve, apresentada por Cecílio (1997), que dá ênfase à autonomia das unidades de produção e à necessidade de implantação de colegiados de gestão que democratizem a tomada de decisões na busca da organização de um sistema, e de relações entre os diversos tipos de produtores de saúde. 
Importante destacar as formulações que vêm sendo produzidas, por Cecílio, com sua linha de investigação sobre organizações, educação permanente, gestão em saúde, entre outras; e as que vêm sendo construídas sobre a micropolítica do trabalho e cuidado em saúde, conduzidas por Merhy (2010) e seus colaboradores, na pós-graduação de Clínica Médica da Universidade Federal do Rio de Janeiro (UFRJ).

Tanto Merhy $(1995,2010)$ quanto Rivera e Artmann $(1999,2010)$, apesar de discordarem do mérito da existência efetiva de escolas de pensamento sobre a temática, em suas análises, trazem reflexões acerca das diferentes tecnologias inerentes ao planejamento no processo de gestão. Propõem uma análise operacional dessas tecnologias, considerando os saberes e práticas nas mais diversas dimensões da realidade social, na busca dos efeitos finais do ato de planejar e dos modelos tecno-assistenciais em questão.

R. Campos (2000) complementa as ideias apresentadas por Merhy (1995) e Rivera e Artmann (1999) ao analisar a produção teórica sobre o planejamento estratégico em saúde no Brasil nos anos noventa. Corrobora com as afirmações destes autores, porém aprofunda a análise da inserção dos sujeitos no processo, e faz também uma abordagem acerca da função teleológica do planejamento, questionando: os métodos dos "meios" são transformados em "fins" em si mesmos? Em nome dos métodos, os sujeitos são sacrificados? O que está na pauta do planejamento atual é o porquê fazer, o como fazer, o saber fazer ou o que fazer?

A autora ainda sinaliza para a necessidade do resgate da potencialidade comunicativa do planejamento, como subsídio para a gestão democrática e para o aprimoramento das tecnologias existentes, com vistas ao atendimento da complexidade dos sujeitos.

Discorre, também, sobre a corrente defendida por Rivera, o "Planejamento Comunicativo", pontuando seus avanços ideológicos, porém sinalizando que a análise dos sujeitos nesta corrente acaba por se reproduzir à determinação matusiana: os sujeitos determinados e "possuídos", e as personalidades como "acúmulos". Isto representa a colonização dos sujeitos pelos meios para atingir determinados fins. R. Campos apresenta a "Gestão Estratégica em Saúde” com dois enfoques: primeiro o que está vinculado 
à questão da instituição de um modelo de gestão, apreendido nas concepções de G. Campos (1992, 1994, 2000) e Merhy (1995), que apresentam o planejamento como técnica capaz de ser simplificada numa tecnologia leve, defendida por Cecílio (1997).

Em sua tese de doutoramento, R. Campos (2003) identifica o planejamento como um dispositivo ${ }^{12}$ por meio do qual os sujeitos trabalham para manter a funcionalidade das organizações, com vistas a produzir novidades e desejos que proporcionem a garantia da qualidade de vida.

A abordagem hermenêutica proposta nesta produção tem o objetivo de proporcionar ao leitor a interpretação histórica do processo de construção do planejamento em saúde, vislumbrando o entendimento do mesmo não enquanto uma tecnologia pronta, mas como um dispositivo, uma práxis, compreendida a partir de sua própria historicidade. Trata-se de uma abordagem que procura aproximar o velho do novo, o saber do fazer, a técnica do ideal e da prudência.

Propõe responder se o planejamento pode se constituir como uma práxis libertadora; se ele subsidiaria um "saber-como" sem, contudo, esmagar a dimensão dos sujeitos e suas singularidades; e se seria possível buscar novas fontes de "saber-fazer" numa interface com outros campos disciplinares.

Teixeira (2003) procura fazer um contraponto com os autores supracitados, analisando os modelos de atenção do ponto de vista teórico-conceitual em relação às práticas que vêm sendo implementadas no âmbito do SUS, não se detendo a análises circunscritas ao objeto do planejamento. Nesse sentido, a autora discute os modelos assistenciais como "formas de organização das relações entre sujeitos mediadas por tecnologias utilizadas no processo de trabalho, cujo propósito é intervir sobre problemas e necessidades sociais de saúde historicamente definidas".

A referida autora discute também como os modelos assistenciais assumem, no campo das concepções, três dimensões: uma gerencial, relativa ao processo de condução da reorganização das ações e serviços de

12 R. Campos (2003) utiliza este termo a partir de Baremblit (2002), justificando que este se ajusta funcionalmente ao poder. Um dispositivo é caracterizado enquanto simultâneo na sua formação, sempre a serviço da produção do desejo, da vida, do novo, etc. 
saúde; outra organizativa, que trata da relação entre unidades de prestação de serviços, levando em conta a hierarquização da complexidade tecnológica no processo de produção do cuidado; e, por fim, uma dimensão operativa, que trata da relação entre o sujeito da prática e o seu objeto de trabalho mediado pelo saber e pela tecnologia.

Teixeira (2003) corrobora com as discussões sobre os modelos assistenciais e o planejamento travado por Merhy (1995), Rivera e Artmann (1999) e G. Campos (2000), apresentando os modelos assistenciais em defesa da vida, ações programáticas em saúde e vigilância da saúde; evidencia a promoção da saúde enquanto corpo doutrinário que origina o movimento de cidades saudáveis, discutindo suas principais características e sua relação com a prática no contexto do Sistema Único de Saúde.

O "modelo assistencial em defesa da vida"13 é apresentado pela autora como centrado no processo de trabalho, com vistas a reorganização das práticas, sendo uma proposta alicerçada numa discussão micropolítica, onde seus autores, segundo ela, descartam a necessidade de se definir uma "imagem-objetivo" de sistema de saúde, suas políticas e diretrizes, suas regras e normas gerais.

O "modelo assistencial das ações programáticas"14 apresenta a programação como tecnologia que pode ser utilizada para a reorganização do processo de trabalho com a implementação de programas especiais de atenção à saúde. Alicerça-se no marxismo estruturalista, no enfoque epidemiológico e na dimensão ética do cuidado; e enfatiza o aperfeiçoamento das práticas pela incorporação crítica dos saberes, dos conhecimentos e das tecnologias disponíveis para a delimitação de objetos de intervenção referidos às necessidades de grupos populacionais específicos. (TEIXEIRA, 2003)

13 Proposta tecno-assistencial desenvolvida pelos teóricos do Lapa-Unicamp que tem como pilares o acolhimento, o vínculo, a responsabilização (contrato) e a autonomia dos sujeitos no processo de definição do cuidado. Uma estratégia de reorganização das práticas a partir da discussão micropolítica e da valorização da subjetividade com base nas ideias do marxismo, da psicanálise e da análise institucional.

14 Proposta tecno-assistencial desenvolvida pelos teóricos da Universidade de São Paulo (USP), também denominada Ação Programática em Saúde. 
O "modelo assistencial da vigilância da saúde"15 é apresentado como sendo um modelo de enfoque sistêmico, embasado pela discussão da reforma sanitária, calcado na ação epidemiológica, na concepção de planejamento estratégico e sediado em territórios específicos, os distritos sanitários, recortados e superpostos como um mosaico que permite a identificação de problemas e necessidades de saúde e das possibilidades de oferta de serviços e intervenções sobre as condições de vida da população. É um modelo que propõe uma articulação das práticas micropolíticas às práticas macropolíticas com vistas a dar conta do princípio da integralidade, tanto numa perspectiva vertical, de organização hierárquica dos serviços de saúde, quanto numa perspectiva horizontal, de organização das ações de promoção, prevenção, proteção, assistência e recuperação da saúde. (TEIXEIRA, 2003)

A Promoção da Saúde é apresentada por Teixeira (2003) como uma combinação de estratégias que envolvem Estado, comunidade, indivíduos e parcerias interinstitucionais para trabalhar propostas de responsabilização mútua nos problemas e soluções relacionados ao processo saúde-doença-cuidado. Sob a compreensão da promoção da saúde, a autora defende que as propostas de reconstituições do processo de trabalho até aqui apresentadas coadunam com a proposta do movimento "cidades saudáveis" ${ }^{16}$, cujas propostas operacionais apontam para o planejamento e execução de ações intersetoriais dirigidas para a melhoria das condições de vida e saúde das populações, incluindo fatores econômicos, ambientais e culturais.

O planejamento, no "labirinto" das discussões tecnológicas travadas até aqui, aproveitando o termo apresentado por R. Campos (2003), se conforma numa confluência de diferentes caminhos, idealizados no intuito de possibilitar transformações sociais a partir da operacionalização de tecnologias desenvolvidas para o trabalho em saúde. Os modelos tecno-

15 Proposta tecno-assistencial desenvolvida entre o final dos anos oitenta e início dos anos noventa, contando com o apoio da OPAS e da Cooperação Italiana em Saúde, tendo como bases organizacionais o modelo Dawson da Inglaterra e o modelo italiano de organização assistencial, que propunham a organização de um sistema de saúde regionalizado e hierarquizado no âmbito de territórios denominados distritos sanitários.

16 Proposta tecno-política de organização da ação governamental de modo intersetorial com vistas a garantir melhoria nas condições de vida e saúde da população nas cidades. 
-assistenciais são o pano de fundo das aspirações tecnológicas do campo do planejamento, ainda que, de fato, a razão instrumental conflite com a prática transformadora que esses modelos preconizam. São espaços de operacionalização de propostas teórico-metodológicas que desafiam o status quo e se instituem como alternativas de organização dos serviços de saúde para a coletividade.

Adotar uma ou outra perspectiva depende da compreensão de modelo assistencial, da compreensão do planejamento e da história da saúde pública brasileira. Depende também do entendimento do papel dos sujeitos sociais e da sua prática, seja no âmbito da gestão, da ação operacional, ou da participação comunitária. Por fim, depende da compreensão do planejamento e de sua conformação nos diferentes espaços coletivos, e de qual a verdadeira missão do planejamento na elaboração de respostas às necessidades de mudança evidenciadas na relação tecnologia-sujeito-práxis.

\section{REFERÊNCIAS}

ARTMANN, E. O Planejamento estratégico situacional: a trilogia matusiana e uma proposta para o nível local de saúde (uma abordagem comunicativa). 1993. 280 f. Dissertação (Mestrado em Saúde Pública) - Escola Nacional de Saúde Pública, Fiocruz, Rio de Janeiro.

; AZEVEDO, C. S.; SÁ, M. C. Possibilidades de aplicação do enfoque estratégico do planejamento no nível local de saúde: análise de duas experiências. Cad. de Saúde Públ., Rio de Janeiro, v.13, n.4, p.723-740, 1997.

; RIVERA, F. J. U. A démarche stratégique (gestão estratégica hospitalar): um instrumento de coordenação da prática hospitalar baseado nos custos de oportunidade e na solidariedade. Ci. Saúde Col., Rio de Janeiro, v. 8, n. 2, p. 479-499, 2003.

BAREMBLIT, G. Compêndio de análise institucional e outras correntes: teoria e prática. 5. ed. Belo Horizonte, MG: Instituto Félix Guatarri, 2002.

CAMPOS, G. W. S. Um método para análise e co-gestão de coletivos. São Paulo: Hucitec, 2000.

. Cogestão e neoartesanato: elementos conceituais para repensar o trabalho em saúde combinando responsabilidade e autonomia. Ci. Saúde Col., Rio de Janeiro, v. 15, n. 5, p. 2337-44, 2010.

; MERHY, E. E.; NUNES, E. D. Planejamento sem normas. 2. ed. São Paulo: Hucitec, 1994. 
CAMPOS, R. T. O. O planejamento no labirinto: uma viagem hermenêutica. São Paulo: Hucitec, 2003.

. Planejamento e razão instrumental: uma análise da produção teórica sobre o planejamento estratégico em saúde, nos anos noventa, no Brasil. Cad. de Saúde Públ., Rio de Janeiro, v. 16, n. 3, p.723-731, 2000.

. O planejamento em saúde sob o foco da hermenêutica. Ci. Saúde Col., Rio de Janeiro, v. 6, n. 1, p. 197-207, 2001.

. Reforma da reforma: repensando à saúde. São Paulo: Hucitec, 1992.

CECÍLIO, L. C. O. A construção de uma cultura institucional de planejamento: a contribuição do município. Saúde em Debate, Rio de Janeiro, n. 31, p. 67-72, 1991.

. (Org.). Inventando a mudança na Saúde. 2. ed. São Paulo: Hucitec, 1997.

CHORNY, A. H. Gerencia estrategica de servicios de salud. Rosario, Argentina: Instituto de la Salud Juan Lazarte, 1996.

. Planificación en salud: viejas ideas em nuevos ropajes. Cuadiernos Medico Sociales, Argentina, v. 73, p. 23-44, 1993.

. Subsídios para a implantação do SUDS no Estado do Rio de Janeiro. Rio de Janeiro: Secretaria do Estado de Saúde, 1987. (Documento para discussão).

FRIEDEN, J. A. O capitalismo global: história econômica e política do Século XX tradução Vivian Mannheimeer. Rio de Janeiro: Jorge Zahar, 2008.

GALLO, E. Razão e planejamento: reflexões sobre política, estratégia e liberdade. São Paulo: Hucitec; Rio de Janeiro: Abrasco, 1995

GIOVANELLA, L. As origens e as correntes atuais do Enfoque Estratégico do Planejamento de Saúde na América Latina. Cad. de Saúde Públ., Rio de Janeiro, v. 7, n. 1, p. 26-44, 1991.

GRAMSCI, A. Concepção dialética da história. 9. ed. Tradução de Carlos Nelson Coutinho.Rio de Janeiro: Civilização Brasileira, 1991.

HABERMAS, J. Consciência moral e agir comunicativo. Tradução de Guido A. de Almeida. Rio de Janeiro: Tempo Brasileiro, 1989.

MATTOS, R.A. As agências internacionais e as políticas de saúde nos anos noventa: um panorama geral da oferta de idéias. Ci. Saúde Col., Rio de Janeiro., v. 6, n. 2, p. 377-89, 2001.

MATUS, C. Política, planejamento e governo. São Paulo: Hucitec, 1993.

MENDES, E. V. As redes de atenção à Saúde. Belo Horizonte: Autêntica, 2009.

. As redes de atenção à saúde. Ci. Saúde Col., Rio de Janeiro, v. 15, n. 5, p. 2297-2305, 2010. 
MERHY, E. E. O ato de governar as tensões constitutivas do agir em saúde como desafio permanente de algumas estratégias gerenciais. Ci. Saúde Col., Rio de Janeiro, v. 4, n. 2, p. 305-314, 1999.

. Em busca do tempo perdido: a micropolítica do trabalho vivo em saúde. In: . O capitalismo e a Saúde Pública. 2. ed. Campinas: Papirus, 1987.

. O conhecer militante do sujeito implicado: o desafio de reconhecê-lo como saber válido. In: FRANCO, T. B et al. (Org.). Acolher Chapecó: uma experiência de mudança do modelo assistencial, com base no processo de trabalho. São Paulo: Hucitec, 2004. p. 21-45.

. Debatedores. Ci. Saúde Col., Rio de Janeiro, v. 15, n. 5, p. 2275-84, 2010.

. Planejamento como tecnologia de gestão: tendências e debates em saúde no Brasil. In: GALLO, E. (Org.). Razão e planejamento: reflexões sobre política, estratégia e liberdade. São Paulo: Hucitec; Rio de Janeiro: Abrasco, 1995. p. 117-148.

. A saúde pública como política: um estudo de formuladores de políticas. São Paulo: Hucitec, 1993.

; ONOCKO, R. (Org.). Agir em saúde: um desafio para o público. São Paulo: Hucitec; Buenos Aires: Lemos Editorial, 1997. p. 71-112.

MENDES, E. V. (Org.). Distrito Sanitário: o processo social de mudança das práticas sanitárias do Sistema Único de Saúde. 4. ed. São Paulo: Hucitec; Rio de Janeiro: Abrasco, 1999.

PAIM, J. S. Aspectos críticos da institucionalização da planificação em organizações públicas de saúde. In: PAIM, J. S. Saúde: política e reforma sanitária. Salvador: Cooptec, 2002. p. 407-34.

. Crise do planejamento autoritário em saúde. Revista da Associação Psiqui-

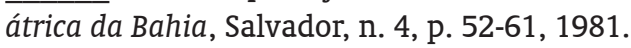

. Epidemiologia e planejamento: a recomposição das práticas epidemiológicas na gestão do SUS. Ci. Saúde Col., Rio de Janeiro, v. 8, n. 2, p. 557-567, 2003.

PAIM, J.S. Gestão do SUDS na Bahia. Cad. de Saúde Públ., Rio de Janeiro, v. 5, n. 4, p. 365-375, 1989.

PAIM, JS. A reorganização das praticas em de saúde em Distritos sanitários. In: MENDES, E. V. (Org.). Distrito Sanitário: o processo social de mudanças das praticas sanitárias do Sistema Único de Saúde. São Paulo/Rio de Janeiro: Hucitec/Abrasco, 1993. p.187-220.

; TEIXEIRA, C. F. Política, Planejamento e gestão em saúde: balanço do estado da arte. Rev. Saúde Públ., São Paulo, v. 40, p. 73-8, 2006. Número especial.

RIVERA, F. J. U.; ARTMANN, E. Planejamento e gestão em saúde: flexibilidade metodológica e agir comunicativo. Ci Saúde Col., v. 4, n. 2, p. 355-65, 1999. 
RIVERA, F. J. U A gestão situacional (em saúde) e a organização comunicante. Cad. de Saúde Públ., Rio de Janeiro, v.12, n.3, p. 357-372, 1996.

RIVERA, F. J. U.; ARTMANN, E. Planejamento e gestão em saúde: histórico e tendências com base numa visão comunicativa. Ci. Saúde Col., Rio de Janeiro, v. 15, n. 5, p. 2265-74, 2010.

RIVERA, F. J. U. Análise estratégica em saúde e gestão pela escuta. Rio de Janeiro: Fiocruz, 2003.

RIVERA, F. J. U. Planejamento e programação em saúde: um enfoque estratégico. 2. ed. São Paulo: Cortez, 1992.

SCHRAIBER, L.B. (Org.). Programação em saúde hoje. 2. ed. São Paulo: Hucitec, 1993.

SCHRAIBER et al. Planejamento, gestão e avaliação em saúde: identificando problemas. Ci. Saúde Col., Rio de Janeiro, v. 4, n. 2 p. 221-42, 1999.

TEIXEIRA, C. F Planejamento e programação da vigilância da saúde. Salvador: Instituto de Saúde Coletva, 1997. 16 p. Mimeografado.

TEIXEIRA, C. F. A construção social do Planejamento e programação local da vigilância a saúde no Distrito Sanitário. In: MENDES, E. V. (Org.). Planejamento e programação local da vigilância da saúde no distrito sanitário. Brasília: OPS, 1994. p. 43-59. (Serie Desenvolvimento dos serviços de saúde, n. 13).

TEIXEIRA, C. F. Epidemiologia e planejamento em saúde: contribuição ao estudo da prática epidemiológica no Brasil. 1990-1995. 1996, 273 f. Tese (Doutorado em Saúde Pública) - Instituto de Saúde Coletiva, Universidade Federal da Bahia, Salvador. . O futuro da prevenção. Salvador: Casa da Qualidade, 2001

. A mudança do modelo de atenção à saúde no SUS: desatando nós, criando laços. Saúde em Debate, Rio de Janeiro, v. 27, n. 65, p. 257-277, 2003

. Planejamento e programação situacional em Distritos Sanitários: metodologia e organização. In: MENDES, E. V. (Org.). Distrito sanitário: o processo social de mudança das praticas sanitárias do SUS. São Paulo: Abrasco; Rio de Janeiro: Hucitec, 1999. p. 231-265. fba, 2010.

. Planejamento em Saúde: conceitos, métodos e experiências. Salvador: Edu-

. 0 processo de formulação da política de saúde da população negra em Salva-

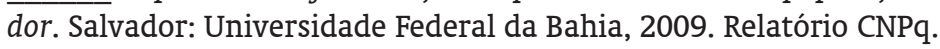

; PAIM, J. S.; VILASBOAS, A. L. SUS, modelos assistenciais e vigilância da saúde. Informe Epidemiológico do SUS, n. 7, 1998.

TESTA, M. Pensamento estratégico e lógica da programação: o caso da saúde. Rio de Janeiro: Hucitec, 1995.

. Pensar en salud. 3. ed. Buenos Aires: Lugar, 2004. 
VILASBÔAS, A. L. Q. Práticas de planejamento e implementação de políticas de saúde no âmbito municipal. 2006. 129 f. Tese (Doutorado em Saúde Pública) - Instituto de Saúde Coletiva, Universidade Federal da Bahia, Salvador. 



\section{CAPÍTULO 3}

\section{Planejamento em saúde no Brasil: configurações e tendências no sistema e nos serviços de saúde}

Washington Luiz Abreu de Jesus

Marluce Maria Araújo Assis

Sisse Figueredo de Santana

Chaider Gonçalves Andrade

Todas as atividades humanas são condicionadas pelo fato de que os homens vivem juntos; mas a ação é a única que não pode sequer ser imaginada fora da sociedade dos homens [...]

Arendt,1997.

\section{INTRODUÇÃO}

No período de efervescência política ocorrida no final da década de 1970 e ao longo do processo de redemocratização do país (década de 1980), se fez necessário construir as bases teórico-metodológicas para sustentar a área de Políticas, Planejamento e Gestão (PP\&G) do campo da Saúde Coletiva. O ponto de partida já estava estabelecido e a discussão desenvolvida pelos teóricos internacionais serviram de subsídio para as primeiras produções brasileiras, cujo objetivo era trabalhar com elementos que possibilitassem a implementação das políticas de saúde com base nos preceitos da Constituição Federal de 1988.

O presente capítulo procura fazer uma releitura das diferentes configurações que tomam como base de análise a construção teórica do planejamento em saúde no Brasil, suas concepções, enfoques e desdobramentos sobre o trabalho na gestão, a exemplo do que foi feito por Merhy (1995, 1997), sem desconsiderar as origens concretas da planificação em Saúde na 
América Latina, alicerçadas nas diversas perspectivas do enfoque estratégico. (GIOVANELLA, 1991) Para compor a análise procura-se evidenciar as produções mais significativas da área que contribuíram para a formulação de um olhar mais atual sobre essas configurações no cenário brasileiro, com vistas a nortear a conformação de diferentes tendências no contexto do SUS.

O planejamento em saúde no Brasil vem se dando, portanto, de modo articulado à discussão dos modelos assistenciais, representados pelas "Ações Programáticas em Saúde" (SCHRAIBER; NEMES; MENDES-GONÇALVES, 2000; SCHRAIBER et al., 1999), pelo "Planejamento Comunicativo" (ARTMANN; RIVERA, 1999; RIVERA, 1995, 2003, RIVERA; ARTMANN, 1999), pela "Vigilância da Saúde" (MENDES, 1999; PAIM, 2003; TEIXEIRA, 1999) e pela "Gestão Estratégica em Saúde". (CAMPOS, G., 1992, 1994, 2000; CECÍLIO, 1997)

As "Ações Programáticas em Saúde" (SCHRAIBER, NEMES; MENDES-GONÇALVES, 2000; SCHRAIBER et al, 1999), concebidas a partir da construção coletiva do conhecimento do processo saúde-doença, subordinam as ações individuais e coletivas a um projeto programático, cujos modelos são tecnologicamente ordenados em serviços de saúde; o "Planejamento Comunicativo" (ARTMANN; RIVERA, 2006; RIVERA, 1995, 2003; RIVERA; ARTMANN, 1999;), cuja introdução do sujeito social dialógico e participativo na esfera do planejamento é imprescindível no trabalho cotidiano; a "Vigilância da Saúde” (MENDES, 1999; PAIM, 2003; TEIXEIRA, 1999), que incorpora em sua metodologia elementos do Planejamento Estratégico Situacional (PES), partindo da identificação de riscos e necessidades de saúde em um dado território, de modo a confeccionar um planejamento pautado sobre os riscos potenciais à saúde; e a "Gestão Estratégica em Saúde" (CAMPOS, G., 1992, 1994, 2000; CECílIO, 1997), que incorpora elementos do PES, do Pensamento Estratégico e da Análise Institucional, sendo resultado do uso de tecnologias no processo de trabalho, numa articulação entre as diferentes arenas decisórias para a consolidação da natureza pública dos serviços de saúde, procurando interconectar o modo de organizar a gestão com as ferramentas do planejamento.

A adoção de qualquer uma dessas perspectivas depende da compreensão de modelo assistencial, bem como do entendimento do papel dos 
sujeitos sociais e da sua prática, seja no âmbito da gestão, da ação operacional, ou da participação comunitária. Por fim, depende também da compreensão do planejamento e de sua conformação nos diferentes espaços coletivos, e de qual a verdadeira missão do planejamento na elaboração de respostas às necessidades de mudança evidenciadas na relação tecnologia-sujeito-práxis.

\section{DIFERENTES CONFIGURAÇÕES PARA O PLANEJAMENTO EM SAÚDE NO BRASIL}

As configurações do planejamento produzidas e operadas no sistema e nos serviços de saúde podem ser sistematizadas em nove perspectivas, com pontos de convergências, divergências e complementaridades, expostos na sequência do texto. Essas perspectivas sintetizam, de modo bastante híbrido, o modus operandi dos processos de planificação aí estabelecidos. O seu mapeamento se deu a partir da leitura e sistematização de artigos científicos produzidos nos últimos vinte anos, disponíveis na base de dados do SciELO e também em capítulos de livros que tratam do planejamento em saúde, editados no período.

\section{PLANEJAMENTO COMO TÉCNICA PARA 'INTERVIR' E 'AVALIAR' SISTEMAS E SERVIÇOS DE SAÚDE}

O "planejamento como técnica" (CAMPOS, R., 2000) se sustenta na definição dos modelos de planejamento em saúde que estariam centrados numa dada instrumentalidade. A técnica para intervir é o poder em ato, ou seja, o poder da técnica incorporado pelo Estado para determinar os meios e os fins para o alcance de determinados objetivos. A técnica para avaliar é o julgamento do poder em ato, ou seja, a verificação da veracidade dos resultados de uma intervenção com base num modelo teórico pré-definido visando estabelecer padrões de qualidade.

No sistema de saúde, a intervenção e a avaliação assumem importantes papéis, pois permitem contribuir para garantir o acesso dos usuários às ações e serviços, por meio de métodos de diagnóstico territorial, identificação de determinantes epidemiológicos, definição de fluxos de atendimento, conformação de modelos de intervenção e de análise comparativa de 
métodos, com vistas a identificar limites e possibilidades de aplicação dos mesmos nos níveis locais. Mesmo reconhecendo que as intervenções ainda carecem de maior articulação com as práticas avaliativas.

De fato o ato de intervir aponta para a interpolação da autoridade, para a utilização do poder e do controle com vistas a influir no decurso de algo. Também pode significar assistir, cooperar, o que nos leva a concluir que a capacidade de intervenção, neste sentido, estaria relacionada a uma capacidade de corresponsabilização na definição de determinada ação.

A avaliação de serviços de saúde é uma prática em construção no Brasil, consistindo em comparar um fato ou fenômeno com um modelo, um padrão ou um conjunto de valores, para definir até que ponto o observado se aproxima do modelo escolhido. Pode-se dizer que é parte inerente ao processo de planejamento e que o próprio diagnóstico é basicamente um processo de avaliação. Configura como um instrumento essencial para que se possa controlar a implementação de um plano e o rumo das mudanças em direção ao objetivo proposto. (PAIM, 2005; CHORNY, 1993)

A avaliação pode produzir informação, tanto para a melhoria das intervenções em saúde, quanto para o julgamento acerca de sua cobertura, acesso, equidade, qualidade técnica, efetividade, eficiência e percepção dos usuários a seu respeito, se considerados os diferentes níveis de complexidade e responsabilidades do sistema e dos serviços de saúde. (VIEIRA-DA-SILVA, 2005; SANTOS; MERHY, 2006)

\section{PLANEJAMENTO COMO PRÁTICA SOCIAL TRANSFORMADORA DE SUJEITOS E COLETIVOS}

A ideia do planejamento enquanto prática social transformadora (MERHY, 1995) sustenta-se na capacidade de determinar novas relações sociais, alternativas à lógica capitalista do processo de regulação ordenada pelo mercado, uma tecnologia de gestão de sociedades. Estaria associada a uma práxis revolucionária, alicerçada nas teorias marxistas e teria como pano de fundo a ideia de que alguns grupos de interesse seriam sujeitos históricos transformadores pela sua ação crítico-revolucionária, sendo, portanto capazes de romper com as linhas de determinações e gerar novos processos sociais. 
O fato de se identificar a prática do planejamento como uma práxis transformadora, demonstra o seu caráter social no cenário brasileiro, ainda que, na essência, não tenha se apartado de certa racionalidade instrumental. O sentido eminentemente teórico deixa de existir no momento em que os sujeitos e os coletivos organizados buscam o horizonte para estabelecer as estratégias de enfrentamento dos problemas socialmente determinados, transformando sua prática em movimentos de acumulação social, o que, por si só, revela o caráter de totalidade da ação transformadora do planejamento da saúde, pela saúde e para a saúde.

No Brasil, a discussão do planejamento como uma práxis transformadora toma corpo no momento em que a academia questiona o enfoque normativo tradicionalmente dado à planificação em saúde e propõe modelos alternativos, contra-hegemônicos, que incluem elementos socialmente determinados na pauta das discussões, buscando alternativas para a mudança no cotidiano das práticas.

Tomando o PES (MATUS, 1993) e o Pensamento Estratégico (TESTA, 1995, 2004) como ferramentas para a luta contra-hegemônica, os sujeitos, conduzindo processos de mudança da sua própria prática, se debruçam sobre os cenários do cotidiano para reconstruir o planejamento e, por fim, transformar a realidade - um enfrentamento histórico e uma utopia ainda perseguida.

A despeito disto, podemos identificar no balanço do estado da arte da área $P \& G$, no campo da saúde coletiva brasileira, realizado por Paim e Teixeira (2006), que tal área expressa com clareza a dupla dimensão (saber e prática) do campo, haja vista que o conhecimento produzido responde a problemas e desafios colocados pelos sujeitos em sua ação política em diferentes contextos históricos. Portanto, o produto dessa luta contra-hegemônica não nega as tecnologias e a racionalidade construídas no planejamento normativo. Propõe uma releitura desses elementos afim de que sejam aplicáveis nas diferentes realidades sociais. 


\section{PLANEJAMENTO COMO SUBSÍDIO PARA A GESTÃO DEMOCRÁTICA E PARA AS MUDANÇAS}

Planejar para a democracia é um exercício de aprendizagem que requer do sujeito capacidade para buscar subsídios para implementar seus propósitos de transformação. (CAMPOS, R., 2000) A gestão democrática deve contar com os subsídios do planejamento para se consolidar. Numa relação democrática o sujeito se torna um condutor de um processo de mudanças (TESTA, 2004) a ser implementado, sendo, portanto, o responsável pela direção a ser seguida para alcançá-las.

Condutor é, portanto, aquele que se coloca como gestor. Para alcançar os objetivos propostos no seu projeto, ele precisa antes de tudo identificar os limites e as possibilidades de implementá-lo, assim como avaliar de forma criteriosa as resistências, os nós críticos, as dificuldades e os possíveis entraves que se coloquem diante de sua proposta. Todavia, para vencer os obstáculos, cabe ao gestor lançar mão de estratégias que dêem conta de preparar o espaço para a batalha e programar ações que levem seu projeto a plena execução no contexto em que se encontra inserido, demonstrando, assim, capacidade de dirigir, gerenciar, administrar e controlar.

A tarefa colocada para uma perspectiva democrática de gestão não seria apenas a da pura e simples repressão de demandas. (CAMPOS, G., 1992) O planejamento e a organização dos serviços de saúde devem ser orientados para intervenções tecnicamente identificadas, porém devem também estar abertos às contingências da vida das pessoas, num processo dialógico de co-produção de necessidades e de construção da consciência sanitária. (CAMPOS, G., 2000) Ou seja, pensar no planejamento para a democracia, enquanto exercício de aprendizagem que requer do sujeito capacidade para buscar subsídios para implementar suas mudanças. Nesse sentido, o sujeito se torna um condutor no processo de mudanças, sendo, portanto, o responsável pela direção a ser seguida para alcançá-las.

Em síntese, o planejamento como um subsídio para a gestão democrática se traduz na compreensão da complexidade social e institucional, e no entendimento da cultura organizacional. É importante na intervenção sobre sujeitos e coletivos institucionalizados, na mediação das relações intersubjetivas e na reorientação das práticas no processo de trabalho para 
gestão da ação com o intuito de organizar a atenção à saúde. (CAMPOS, R., 2000)

\section{PLANEJAMENTO COMO PRÁTICA ESTRUTURADA PARA A ORGANIZAÇÃO DE SISTEMAS E SERVIÇOS DE SAÚDE}

A aproximação entre estratégia e arte de aplicar com eficácia os recursos, permite que se reflita sobre a possibilidade do "planejamento enquanto um conjunto de práticas estruturadas para organização de sistemas e serviços de saúde". (VILASBÔAS, 2005; JESUS, 2006) A identificação do ato de planejar é uma arte em si mesmo, no sentido dado aqui ao planejamento como o conjunto de estratégias, que de fato possibilita organizar de modo eficaz os recursos disponíveis, sejam materiais ou não materiais, com vistas a uma imagem objetivo-concreta - a constituição de sistemas locais de saúde resolutivos.

O planejamento da organização de sistemas e serviços de saúde com base num modelo de atenção que dê conta das necessidades sociais vem sendo travado, no cenário brasileiro, desde o final da década de $70 \mathrm{com} o$ movimento da Reforma Sanitária, quando diversos sujeitos trabalharam para desenvolver propostas metodológicas que possibilitassem desenvolver sistemas locais de saúde, numa perspectiva intersetorial, capazes de responder aos princípios da universalidade, da equidade e da integralidade na assistência. (PAIM, 2003; RIVERA, 2003)

Os Sistemas Locais de Saúde se constituem como um projeto dinamizador das estratégias do movimento "Saúde para Todos no ano 2000" (SPT-2000), iniciado no Brasil no final da década de oitenta com a criação do Sistema Unificado e Descentralizado de Saúde (SUDS), estendendo-se até a década de noventa, com a implementação da municipalização da saúde. É uma resposta do setor aos processos de democratização do Estado na busca da equidade, eficácia e eficiência das ações. Organizam-se teórico-metodologicamente na denominada "trilogia matusiana" - o PES, o Método Altadir de Planificação Popular (MAPP) e o Planejamento de Projetos Orientado por Objetivos (ZOPP) - aplicada numa base territorial denominada Distrito Sanitário. (MENDES, 1999; TEIXEIRA, 1999) 
O planejamento e a programação local de saúde se constituem em processo social e histórico, como instrumento de transformação da prática gerencial nos distritos sanitários, além de loci de operacionalização das ações de saúde. Adota uma perspectiva situacional, cujo enfoque implica eleger como objeto privilegiado de intervenção os problemas de saúde da população. Seria o processo de reorientação do sistema de saúde de acordo com os princípios doutrinários supracitados para a transformação das relações entre oferta e demanda dos serviços, isto é, reorganização das práticas de saúde em seu conteúdo técnico-econômico e político, dirigindo-as à solução dos problemas. (ARTMANN; RIVERA, 2006)

A organização de sistemas locais de saúde, portanto, demanda um aparato tecnológico alicerçado no planejamento intersetorial desenvolvido num dado território para atender às necessidades sociais de uma dada população, num dado período, contribuindo para reorganizar as práticas, a partir do desenvolvimento de uma consciência sanitária nos diferentes sujeitos que compõem o território do cuidado em saúde.

Caracteriza-se por um mix teórico-metodológico, desenvolvido a partir dos conhecimentos acumulados nos espaços de construção do conhecimento e operacionalizado nos cenários municipais do sistema de saúde, cuja potencialidade do planejamento é para organizar modelos de atenção, estabelecendo nexos diferenciados no acesso dos usuários aos serviços de saúde; identificar necessidades, utilizando-se de instrumentos de aferição individuais e coletivos; intervir sobre a realidade, monitorando e minimizando riscos; e sistematizar o diálogo entre os sujeitos sociais, utilizando-se de métodos participativos de escuta e atuação na promoção da saúde.

\section{PLANEJAMENTO COMO MÉTODO DE AÇÃO GOVERNAMENTAL PARA A TOMADA DE DECISÕES}

A ideia de um "planejamento como instrumento/atividade de ação de governo para a produção de políticas" procura evidenciar uma tecnologia de gestão de políticas públicas setoriais, capazes de intervir no processo socioeconômico para direcionar o desenvolvimento social e para controlar parte da relação Estado/sociedade. (MERHY, 1995) 
A perspectiva apresentada (CAMPOS, G., 2000; MERHY, 1995) demonstra similaridade ao processo de planificação econômica vivido pela América Latina a partir da década de 1960, quando da instituição do Método CENDES/OPS como modelo de planificação para os países em desenvolvimento. (RIVERA, 1995) Decerto que a concepção de instrumento/atividade, intrinsecamente conjugados, reforça a ideia de racionalidade conferida ao planejamento, restringindo-o a uma sucessão de etapas operacionais cujos cálculos subsidiam a tomada de decisão dos governantes.

O enfoque normativo se sobressai ao enfoque estratégico, pois o cálculo de governo toma como diretriz majoritária o indicador da economia e a organicidade do processo, que assumem um caráter sistêmico funcional, instrumentalizado pela técnica. Alicerça-se no princípio do equilíbrio e define que a racionalidade formal deve influenciar ou controlar a racionalidade material. (MATUS, 1993)

A lógica da tomada de decisões extrapola, na atualidade, a concepção de método puramente relacionado ao cálculo econômico. É necessário um cálculo estratégico que transcenda esta dimensão. Necessário se faz introduzir elementos da prática para completar e dar sentido à dimensão social do planejamento, enquanto um conjunto de métodos de auxílio ao gestor no momento da tomada de decisões.

A eficácia econômica não é independente da eficácia política, e os processos de governo são equilibrados por relações políticas e econômicas que se contrapõem às relações de forças e às acumulações. Importa que o cálculo político seja cálculo interativo, determinado, como num jogo, pela posição dos jogadores. (CHORNY, 1993) No caso, os sujeitos em situação de governo.

As decisões políticas subsidiam o ato do planejamento e vice-versa, configuram-se em ações para o futuro e expressam valor de uso para o planejamento. As decisões técnicas e administrativas configuram-se num conjunto sistemático de regras e procedimentos baseados na racionalidade instrumental, cujas finalidades apontam para a eficiência e eficácia da relação teoria-método-técnica. (CAMPOS, G, 1992, 1994; CECíLIO, 1997; MENDES, 1999; PAIM, 2003; TEIXEIRA, 1999) 


\section{PLANEJAMENTO COMO INSTRUMENTO E ATIVIDADE DO PROCESSO DE GESTÃO DAS ORGANIZAÇÕES}

A perspectiva analítica de "planejamento como instrumento/atividade do processo de gestão das organizações" (MERHY, 1994) significa uma tecnologia de controle da ação organizacional calcada na perspectiva sistêmico-funcional. Esta concepção de planejamento aponta para a capacidade técnica de intervir e a administrativa de operacionalizar. Fundamenta-se na Teoria Geral da Administração (TGA), que opera sobre a organização do processo de trabalho visando à construção de procedimentos eficazes que otimizem os meios de trabalho na busca de uma maior produtividade ${ }^{1}$. 0 planejamento, nesse sentido, tem-se associado ao conjunto dos procedimentos administrativos como práticas reguladoras da gestão das organizações.

O planejamento seria instrumento, pois é o recurso tecnológico através do qual as organizações chegariam ao que se convenciona chamar de imagem-objetivo. Seria também atividade, já que, se intrinsecamente relacionado ao conhecimento dos sujeitos, possibilitaria estabelecer estratégias diferenciadas de enfrentamento das adversidades que porventura surjam.

Teria a função de propiciar um processo de mudanças através de cálculos interativos para alcançar eficácia e eficiência; também, para intervir nessas organizações com vistas a organizar os processos de trabalho e, no caso da saúde, estruturar mecanismos de acesso e acessibilidade dos usuários aos serviços de saúde; e, por fim, a partir do controle administrativo, analisar o desempenho e a qualidade da produção do cuidado em saúde.

\section{PLANEJAMENTO COMO MEIO DE INTERVENÇÃO EM AMBIENTES COMPLEXOS}

A complexidade é a união entre a unidade e a multiplicidade, isto é, se revela quando elementos diferentes são inseparáveis constitutivos do todo (como o econômico, o político, o sociológico, o psicológico, o afetivo, o mitológico), e há entre eles interdependência, interatividade e inter reatividade. (TESTA, 1995) 
O entendimento explicitado nessa consideração é de que o complexo se aproxima daquilo que poderíamos denominar totalidade intersubjetiva, ou seja, o todo, composto por parte, individualmente, porém capaz de manter uma relação que lhes permita constituir-se enquanto um todo indivisível, único.

No âmbito dos serviços de saúde, o planejamento se dá, nessa perspectiva, como meio de intervenção e de avaliação sobre os processos de trabalho que se desenvolvem nesses serviços e como meio de intervenção sobre os sujeitos e coletivos nessas organizações, consideradas como "complexas". Tal concepção emerge como uma teoria para reorganizar o trabalho numa parceria sinérgica, cujos limites e possibilidades se expressam continuamente por meio do diálogo e da negociação, tendo em conta a necessidade de uma combinação de diferentes racionalidades, desde a instrumental até a comunicativa, na medida em que seja possível operar com ela. (CAMPOS, R., 2000; TESTA, 2004)

\section{PLANEJAMENTO COMO MEIO DE AÇÃO COMUNICATIVA}

O "planejamento como meio de ação comunicativa" parte da crítica ao modelo puramente estratégico, mapeando seus limites e estabelecendo um novo entendimento acerca do seu caráter. Apresenta o planejamento como uma "ferramenta" organizacional que faz parte de um processo mais amplo de desenvolvimento das organizações, valorizando a condução da ação, cujas possibilidades são interpretadas como mediadas/subordinadas à cultura das organizações. (CAMPOS, G., 1994)

O lócus do planejamento nessa perspectiva é o serviço de saúde, que assume postura diferenciada na relação com seus colaboradores, estabelecendo o diálogo, a liderança, a negociação e a problematização coletiva como caminhos para os processos gerenciais. Uma organização cujos princípios apontam para a desconcentração de poder e delegação de competências que, na medida do possível, proporcione uma gestão criativa por operações e por objetivos. (NEMES; MENDES-GONÇALVES, 2000; RIVERA, 1995; SCHRAIBER; SCHRAIBER et al., 1999) Também considera o processo 
de gestão como oportunidade para construir o aprendizado institucional, tal qual explicitado na perspectiva do learning organization. (RIVERA, 2001)

As linhas de investigação para consolidar essa proposta se assentam na análise da cultura enquanto componente de viabilidade do projeto; no desenvolvimento das habilidades de liderança e de negociação; na discussão teórica sobre a relação entre a gestão pela escuta e os métodos racionalistas de gestão; na aplicação sistemática da prospectiva enquanto recurso do cálculo estratégico; nas possibilidades de diálogo entre o PES e os enfoques da administração estratégica e do planejamento estratégico corporativo, favorecendo o mix público/privado; e o resgate da subjetividade no campo da gestão, em processos de construção coletiva de projetos institucionais, a partir do conceito amplo de razão. (RIVERA, 1996, 2003; RIVERA; ARTMANN, 1999, 2006)

\section{PLANEJAMENTO COMO MEDIAÇÃO ENTRE A INSTRUMENTALIDADE E A SUBJETIVIDADE}

R. Campos (2003) desenvolve a ideia de que a ação racional é inseparável dos momentos singulares e subjetivos dos grupos. Ou seja, ela nunca está desvinculada do posicionamento subjetivo dos que planejam e executam. Assim, apesar das limitações do planejamento como tecnologia, ele pode muito bem, nos grupos, vir a ser um dispositivo. Defende o planejamento como uma atividade teleológica: ação racional dirigida para fins, e que essa função está diretamente ligada ao valor de uso do planejamento como prática social. Dessa forma, o planejamento se configura como uma atividade com valor de uso, em que sua função de operar nos meios é central para o logro de sua competência técnica.

Portanto, para Cecílio (2010) está cada vez mais claro um importante desafio teórico e político para alcançar uma melhor compreensão do singular funcionamento das organizações de saúde, em particular o quanto elas têm uma vida própria, uma "micropolítica" marcada pelo autogoverno dos seus trabalhadores. Dessa forma, Cecílio e R. Campos reconhecem a importância de temas como a subjetividade e as relações que atravessam e produzem as organizações. 
G. Campos (2000) parte da crítica a Taylor e defende um novo método para co-governar organizações de saúde, considerando-se tantos os objetivos primários destas instituições, quanto outros secundários, ligados à função de assegurar a sobrevivência e realização profissional de seus trabalhadores. Nessa perspectiva, R. Campos (2003) corrobora com G. Campos (2000) a partir do momento em que assume duas finalidades para as organizações de saúde: a defesa da vida e a eficácia e, por outro, a promoção de uma forma de subjetivação grupal que permita a realização pessoal dos trabalhadores.

Para R. Campos (2000) é função do planejamento fazer mediação entre o objetivo do trabalho em saúde (as finalidades) e o reconhecimento-intervenção sobre a subjetividade dos grupos que estão em ação. Assim sendo, concebe a ideia do planejamento como mediação. Portanto, compreendemos o planejamento como um modo de prover a eficácia em seus processos com uma finalidade: a saúde, reconhecendo a intervenção da subjetividade dos grupos em ação: os trabalhadores de saúde.

\section{A TÍTULO DE CONSIDERAÇÕES FINAIS - TENDÊNCIAS DO PLANEJAMENTO NO SUS}

Considerando o planejamento enquanto "enfoque estratégico situacional", observa-se uma tendência teórico-metodológica das perspectivas contra-hegemônicas de planejamento desenvolvidas na América Latina e incorporadas no Brasil, a partir da década de oitenta. Nesse sentido, o PES desenvolvido por Matus; o Pensamento Estratégico, desenvolvido por Testa; a proposta de Medellín, desenvolvida pela Universidade Central da Venezuela; e a Gestão Estratégica Hospitalar (Demarque Stratégique), desenvolvida por Crémadez e Grateau (França). (CAMPOS, R., 2000)

As características do enfoque estratégico situacional podem ser identificadas como um conjunto de tendências historicamente consolidadas, baseadas no conhecimento técnico, político e administrativo; centradas na atuação dos atores sociais em situação; estabelecidas em momentos operacionais, onde o diagnóstico é um momento de reconhecimento da realidade; aplicam-se no contexto macropolítico e no contexto das organizações complexas; adotam os conceitos de estratégia e tática; e estabe- 
lecem o conhecimento da realidade como ponto de partida para o pensar estratégico.

O "enfoque analítico institucional", como um novo modelo de abordagem para o planejamento em saúde, se mostra a partir dos saberes da dialética, da psicanálise e da pedagogia. (CAMPOS, G., 1992, 1994; CAMPOS, R., 2000; CECíLIO, 1997) É uma tendência atual em constante construção; centrada nos saberes não estruturados e na atuação dos sujeitos da práxis; estabelecida em fluxogramas analisadores, onde o diagnóstico é um produto do processo técnico-político, pedagógico e analítico; aplica-se no contexto micropolítico e no contexto das organizações complexas; adota os conceitos de dispositivo, legitimação, mudança institucional; e estabelece o conhecimento do cotidiano como ponto de partida para a intervenção.

O "enfoque comunicativo" (RIVERA, 1995; RIVERA; ARTMANN, 1999) apresenta-se também como uma tendência atual baseada na teoria da ação comunicativa; centrado na atuação dos sujeitos em negociação; estabelecido em instantes de diálogo, onde o diagnóstico é um momento de aprendizagem sobre a realidade; aplica-se no contexto micropolítico e no contexto das organizações complexas; adota os conceitos de liderança e negociação; e estabelece o paradigma da organização que aprende como ponto de partida para mudança institucional.

Por fim, identifica-se o "enfoque participativo", um novo elemento conceitual, alicerçado no paradigma da participação que pode ser incorporado na prática do SUS (ASSIS; PEREIRA; MISHIMA, 1997; GANDIN, 2001; LIMA; FAVERET; GRABOIS, 2006) como uma tendência (uma escola) dentro do campo de propostas de ferramentas para intervir sobre a realidade, transformando-a e construindo-a numa direção estabelecida em conjunto por todos os que participam de uma organização, instituição, grupo ou movimento. Trata-se de um enfoque que inclui a distribuição do poder e a possibilidade de decidir na construção não apenas do "como" ou do "com que" e "com quem" fazer, mas também, do "o quê", do "para quê" ou "para quem" fazer.

Essa 'nova' tendência de planejamento se estabelece no contexto do Sistema Único de Saúde (JESUS, 2006) como uma alternativa, inclusive aos enfoques estratégico, analítico institucional e comunicativo, pois carrega 
em si elementos que vão desde a concepção estratégica até a análise dos sujeitos enquanto históricos e definidores do processo de transformação social.

As quatro tendências apresentadas remetem à "discussão do sujeito da transformação no planejamento", que se estabeleceram como propostas alternativas no processo de gestão nos diferentes níveis do SUS e nas organizações de saúde. Enfoques que resgatam o ponto de partida da construção do SUS - a questão do planejamento enquanto uma possibilidade a ser construída como ferramenta balizadora da reforma do sistema de saúde brasileiro.

\section{REFERÊNCIAS}

ARTMANN, E.; RIVERA, J. F. U. Humanização no atendimento em saúde e a gestão comunicativa. In: DESLANDES, S. (Org.). Humanização dos cuidados em saúde: conceitos, dilemas e práticas. Rio de Janeiro: Fiocruz, 2006. p. 205-231.

ASSIS, M. M. A; PEREIRA, M. J. B; MISHIMA, S. M. Planejamento em saúde: uma possibilidade de ação participativa. Rev. Latino-Am. Enferm., Ribeirão Preto, v. 5, n. 4, p. 55-60, 1997.

CAMPOS, G. W. S. Um método para análise e cogestão de coletivos. São Paulo: Hucitec, 2000. p. 10-175.

. Reforma da reforma: repensando a saúde. São Paulo: Hucitec, 1992.

. A saúde pública e a defesa da vida. 2. ed. São Paulo: Hucitec, 1994. p. 14-85.

CAMPOS, R. T. O. O planejamento no labirinto: uma viagem hermenêutica. São Paulo: Hucitec, 2003.

. Planejamento e razão instrumental: uma análise da produção teórica sobre o planejamento estratégico em saúde, nos anos noventa, no Brasil. Cad. de Saúde Públ. Rio de Janeiro, v.16, n. 3, p.723-731, 2000.

CECÍLIO, L. C. O. É preciso politizar o SUS. Ciência \& Saúde Coletiva, v. 15, n. 5, p. 2276-2280, 2010. p.15-198.

(Org.). Inventando a mudança na Saúde. 2. ed. São Paulo: Hucitec, 1997.

CHORNY, A. H. Planificación en salud: viejas ideas en nuevos ropajes. Cuadiernos Medico Sociales, Buenos Aires, v. 73, p. 23-44, 1993.

GANDIN, D. A posição do Planejamento Participativo entre as ferramentas de intervenção na realidade. Currículo sem Fronteiras,v. 1, n.1, p. 81-95, 2001. Disponível 
em: < http://www.curriculosemfronteiras.org/vol1iss1articles/gandin.pdf>. Acesso em: 18 jun. 2011.

GIOVANELLA, L. As origens e as correntes atuais do enfoque Estratégico do Planejamento de Saúde na América Latina. Cad. de Saúde Públ., Rio de Janeiro, v. 7, n. 1, p. 26-44, 1991.

JESUS, W.L.A. Ressignificação do planejamento no campo da Saúde Coletiva: desafios teóricos e busca de novos caminhos. Dissertação (Mestrado em Saúde Coletiva) Universidade Estadual de Feira de Santana. Feira de Santana, Bahia, 2006. 236 p.

LIMA, J. C.; FAVERET, A. C.; GRABOIS, V. Planejamento participativo em organizações de saúde: o caso do Hospital Geral de Bonsucesso, Rio de Janeiro, Brasil. Cad Saúde Públ., Rio de Janeiro, v. 22, n.3, p. 631-41, 2006.

MATUS, C. Política, planejamento e governo. São Paulo: Hucitec, 1993.

MENDES E.V. (Org.). Distrito Sanitário: o processo social de mudança das práticas sanitárias do Sistema Único de Saúde. 4. ed. São Paulo: Abrasco, 1999.

MERHY, E. E. Em busca do tempo perdido: a micropolítica do trabalho vivo em saúde. In: MERHY, E. E.; CAMPOS, R. (Org.). Agir em saúde: um desafio para o público. São Paulo: Lemos Editorial; Buenos Aires: Hucitec, 1997. p.71-112.

. Planejamento como tecnologia de gestão: tendências e debates em saúde no Brasil. In: GALLO, E. (Org.). Razão e planejamento: reflexões sobre política, estratégia e liberdade. São Paulo: Abrasco, 1995. p. 117-148.

PAIM J. S. Avaliação em saúde: uma prática em construção no Brasil. In: HARTZ, Z. M.; VIEIRA-DA-SILVA, L.M (Org.). Avaliação em saúde: dos modelos teóricos à prática na avaliação de programas e sistemas de saúde. Salvador: Edufba; Rio de Janeiro: Fiocruz; 2005. p 9-10.

. Epidemiologia e planejamento: a recomposição das práticas epidemiológicas na gestão do SUS. Ci. Saúde Col., Rio de Janeiro, v. 8, n. 2, p. 557-67, 2003.

; TEIXEIRA, C. F. Política, Planejamento e gestão em saúde: balanço do estado da arte. Rev. Saúde Públ., São Paulo, v. 40, p. 73-8, 2006. Número especial.

RIVERA, F. J. U. Agir comunicativo e planejamento social (uma crítica ao enfoque estratégico). Rio de Janeiro: Fiocruz, 1995. p. 190-213.

. Análise Estratégica em Saúde e Gestão pela escuta. 2. ed. Rio de Janeiro:

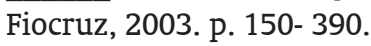

Planejamento estratégico situacional ou controle de qualidade total em saúde? Um contraponto teórico-metodológico. Cad. FUNDAP, São Paulo, v.19, p. 25-46, 1996.

. Planejamento e programação em saúde: um enfoque estratégico. 2. ed. São Paulo: Cortez; 1992: 7-89. 
. Reflexões sobre a subjetividade na gestão a partir do paradigma da organização que aprende. Ci. Saúde Col. Rio de Janeiro, v. 6, n. 1, p. 209-219, 2001.

; ARTMANN, E. A liderança como intersubjetividade linguística. Interf- Comunic., Saúde, Educ., Botucatu. v. 10, n. 20, p. 411-426, 2006.

; ARTMANN, E. Planejamento e gestão em saúde: flexibilidade metodológica e agir comunicativo. Ci Saúde Col., v. 4, n. 2, p. 355-65, 1999.

SANTOS, F. P.; MERHY, E. E. A regulação pública da saúde no estado brasileiro: uma revisão. Interf-Comunic., Saúde, Educ., Botucatu, v. 10, n. 19, p. 25-41, 2006.

SCHRAIBER, et al. Planejamento, gestão e avaliação em saúde: identificando problemas. Ci. Saúde Col., Rio de Janeiro, v. 4, n. 2 p. 221-42, 1999.

SCHRAIBER, L. B; NEMES, M. I. B; MENDES-GONÇALVES, R. B. Saúde do adulto - Programas e ações na Unidade Básica. 2. ed. São Paulo: Hucitec, 2000, p. 22- 323.

TEIXEIRA, C. F. Epidemiologia e planejamento em saúde. Ci Saúde Col., Rio de Janeiro, n. 4, p. 287-303, 1999.

TESTA, M. Pensamento estratégico e lógica da programação: o caso da saúde. São Paulo: Hucitec, 1995.

. Pensar en salud. 3. ed. Buenos Aires: Lugar Editorial, 2004.

VIEIRA-DA-SILVA, L. M. Conceitos, abordagens e estratégias para avaliação em saúde. In: HARTZ, M. A; VIEIRA-DA-SILVA, L.M. (Org.). Avaliação em Saúde: dos modelos teóricos à prática na avaliação de programas e sistemas de saúde. Salvador: Edufba; Rio de Janeiro: Fiocruz, 2005. p.15-40. 



\title{
CAPÍTULO 4
}

\section{Revisão sistemática sobre o conceito de acesso nos serviços de saúde: contribuições do planejamento ${ }^{1}$}

Washington Luiz Abreu de Jesus

Marluce Maria Araújo Assis

\begin{abstract}
[...] A despeito da realidade cruel do acesso aos serviços de saúde, de acordo com as necessidades socialmente determinadas, é possível construirmos a consciência cidadã, derrotarmos o conformismo social, por meio da emancipação dos sujeitos históricos capazes de intervir em diferentes realidades dos serviços, e garantirmos o acesso universal e equitativo como construção social no atendimento às necessidades da população.
\end{abstract} Assis et al, 2010.

\section{INTRODUÇÃO}

Este capítulo apresenta uma revisão e análise dos conceitos de acesso aos serviços de saúde, contemplando o processo de construção do Sistema Único de Saúde (SUS), com a pretensão de estabelecer conexões entre a discussão teórica e a prática do planejamento no campo da Saúde Coletiva.

Inicia-se a discussão trazendo a definição de acesso, que segundo o Dicionário Houaiss da Língua portuguesa (2001, p. 52) é o “[...] ato de ingressar, entrada, ingresso; possibilidade de chegar a, aproximação, chegada; possibilidade de alcançar algo". Ao estabelecer uma relação desta definição com os serviços de saúde, pode ser entendida como "porta de entrada", como o local de acolhimento do usuário no momento de expressão de sua necessidade e, de certa forma, aos caminhos percorridos por ele no sistema na busca da resolução dessa necessidade.

1 Texto publicado em forma de artigo na revista Ciência \& Saúde Coletiva, v.15, n.1, jan. p. 161-170, 2010 . 
Pustai (2004) discute acesso no contexto dos princípios do SUS, explicitando suas características legais e suas características históricas e a função teleológica - ação racional organizada para produzir um fim, uma finalidade - da cidadania na produção dos serviços de saúde.

$\mathrm{O}$ acesso universal aos serviços de saúde, além de ser uma garantia constitucional, é uma bandeira de luta dos movimentos sociais, nos quais essa reivindicação passou a ser um dos elementos fundamentais dos direitos de cidadania. E, nesse caso, o exercício de cidadania tem um grande potencial de produzir resultados concretos, tendo em vista as reais possibilidades de mudança e melhora no atendimento aos problemas de saúde da população. (PUSTAI, 2004)

Nessa perspectiva, o acesso vai além da conexão pura e simples ao conceito de porta de entrada, configura-se como um "dispositivo" transformador da realidade. Partindo da concepção de que somente se garantirá o ingresso universal do usuário no sistema de saúde através da consciência de cidadania, corroborando com a ideia de G. Campos (1992), que determina como elemento reformador do pensamento da sociedade para a construção de sistemas de saúde, de acordo com as necessidades socialmente determinadas, a consciência sanitária.

R. Campos (2003) apresenta o "dispositivo", definido como aquilo que propicia, faz advir. Pode-se dizer que esse termo configuraria uma nova concepção se não estivesse engendrado por um número significativo de elementos que o destaque ao nível de categoria analítica. $O$ fato é que considerar o planejamento um dispositivo é nada mais que assumir o fato de ser "ele" o elemento disparador de uma série de acontecimentos que culminam por confluir com os objetivos ou finalidades, o processo esperado da transformação ou manutenção da ordem estabelecida.

É sob a égide da concepção de dispositivo que o planejamento no campo da Saúde Coletiva se institui com vistas a garantir o acesso dos brasileiros aos serviços de saúde e como categoria analítica importante na construção teórico-prática do cotidiano no SUS. Assim, os conceitos da temática em discussão extrapolam a dimensão de elemento de análise e se colocam como categoria analítica, permeada por elementos históricos, numa perspectiva de transformação da realidade. 
Para o desenvolvimento do texto, apresentam-se as dimensões analíticas do conceito de acesso, sintetizadas a partir da re-interpretação de teóricos da área; em seguida, numa tentativa de esforço de síntese, discutem-se os dispositivos do planejamento em saúde relacionados às diferentes dimensões de análise: econômica, técnico-assistencial, política e simbólica.

\section{ACESSO COMO CATEGORIA ANALÍTICA - CONEXÃO ENTRE TEORIA E PRÁTICA DO PLANEJAMENTO NO CAMPO DA SAÚDE COLETIVA}

Giovanella e Fleury (1996) discutem que o acesso é categoria central para a análise das interrelações usuários/serviços de saúde. Apresentam-no como um conceito geral que sumariza o conjunto de dimensões específicas que descrevem a adequação entre os usuários e o sistema de cuidados em saúde. Discutem-no à luz dos modelos teóricos das diversas conceituações do termo ao longo da história.

No tocante às dimensões específicas, a "disponibilidade" é entendida como relação entre o volume e os tipos de serviços existentes, o volume de usuários e os tipos de necessidades; a "acessibilidade", como a relação entre localização da oferta e dos usuários, levando em conta os recursos para transporte, o tempo de viagem, a distância e os custos; a "acomodação ou adequação funcional", entendida como a relação entre o modo como a oferta está organizada para aceitar os usuários e a capacidade/habilidade dos usuários acomodarem-se a esses fatores e perceberem a conveniência dos mesmos; a "capacidade financeira", como relação entre os custos dos serviços, seja de entrada, de manutenção ou de saída; e, por fim, a "aceitabilidade", entendida como a relação entre as atitudes dos usuários sobre os trabalhadores de saúde e sobre as características das práticas dos serviços, bem como a aceitação dos trabalhadores e dos serviços em prestar assistência a esses usuários. (GIOVANELLA; FLEURY, 1996)

A relação entre a categoria em discussão e o planejamento da saúde vem sendo construída historicamente, a partir da análise dos modelos teóricos construídos no decurso de momentos intimamente relacionados aos contextos, nos quais se desenvolveram as suas diferentes conceituações. 
O "modelo economista" (GIOVANELLA; FLEURY, 1996) estaria relacionado ao mapeamento dos diferentes padrões de consumo dos indivíduos que influenciariam na relação entre a oferta de serviços e a demanda pelos mesmos. A intervenção estatal seria capaz de moldar a forma de organização da produção da assistência médica e a conformação da demanda, a partir de diferentes grupos populacionais para alcançar os bens e serviços de saúde.

O planejamento, nesse sentido, visa responder a uma demanda pré-determinada, isto é, determinada pela relação entre o poder do consumidor e a capacidade de oferta do fornecedor. $\mathrm{O}$ ato de planejar para a oferta é uma consequência dos levantamentos de demanda para a constituição de serviços de saúde, de acordo com os padrões de consumo da população referenciada. Usuários são consumidores e o Estado o ente regulatório de mediação, da relação usuário/serviço.

O "modelo sanitarista-planificador" se caracteriza pela concepção de acesso enquanto possibilidade de consumo, garantida pela distribuição planejada de recursos na rede de serviços hierarquizada, através de um sistema de organização baseado nos princípios da referência e contra-referência. (GIOVANELLA; FLEURY, 1996) Os processos administrativos seriam ágeis com garantia de informação adequada ao usuário sobre os procedimentos e serviços existentes para a sua utilização.

Trata-se de um modelo numa visão técnica, pautado na concepção da uniformidade, estabelecido através da atuação dos sujeitos planejadores vinculados ao aparelho do Estado. Isto é, os sanitaristas são os sujeitos do planejamento a serviço do Estado. Está intrinsecamente ligado à ideia do "planejamento normativo re-formado", ou seja, um modelo de planificação que se aproveita da tecno-burocracia para estabelecer os dispositivos de garantia do acesso dos usuários aos serviços de saúde - um resgate da razão instrumental, apontada por R. Campos (2003), porém numa dimensão diferenciada, re-inventada no aparelho burocrático do Estado, cujos resultados estariam relacionados a gradientes de eficácia, eficiência e efetividade, obtidos a partir da integração de recursos da epidemiologia, da administração pública e da saúde pública. 
O "modelo sanitarista-politicista" surge como um outro olhar sobre a discussão do acesso e sua relação com o planejamento no campo da Saúde Coletiva. Alicerçado na concepção formulada por Berlinguer (1978) e analisada por G. Campos (1992, 2000) e Giovanella e Fleury (1996), em que a população adquire a capacidade cognitiva de compreender as determinações sociais do processo saúde/doença e os fatores que determinam a organização social da prática médica, num processo de (des) alienação, ou seja, rompimento com as deformações impostas pela sociedade à consciência sanitária, entre as quais a medicalização dos desgastes impostos pelo processo de trabalho.

O acesso, na perspectiva do "modelo sanitarista-politicista", é um direito individual e coletivo adquirido constitucionalmente, num conceito ampliado, de base marxista, explicitando a construção do sistema e a conformação das práticas de maneira participativa, com cidadania, intervindo na gestão através do controle social.

Por fim, o "modelo das representações sociais" é apresentado por Giovanella e Fleury (1996) como uma nova possibilidade na determinação do acesso como categoria de análise e do planejamento. Partem do princípio que a realidade é uma constituição eminentemente intersubjetiva e simbólica do processo saúde-doença, em que os sujeitos coletivos e históricos são seus artífices, suportes e mediadores. Significa dizer que a base das representações sociais é o substrato social. (MINAYO, 2004) Os sujeitos são coletivos e históricos, pois estão imersos na história, dela fazem parte e nela se sustentam nos momentos em que a consciência coletiva, instituída a partir das relações de dominação, conflita com a realidade subjetiva.

Ao tratar a questão do acesso a partir das possibilidades de aproximação com os serviços de saúde, deve-se ter em conta uma visão compreensiva, na qual seja possível comportar uma dimensão econômica, referente à relação entre oferta e demanda; uma visão técnica, relativa à planificação e a organização da rede de serviços; uma visão política, relativa ao desenvolvimento da consciência sanitária e da organização popular; e uma dimensão simbólica, relativa às representações sociais acerca da atenção e do sistema de saúde. (GIOVANELLA; FLEURY, 1996) 
Com base no modelo analítico desenvolvido por Giovanella e Fleury (1996), re-significado por Assis, Villa e Nascimento (2003) e aprofundado por Jesus (2006), partiu-se para um outro movimento interpretativo, tomando como referencial teórico Santos (2003) e Albuquerque (1986). O esforço de análise possibilitou estabelecer uma síntese explicativa, retratada no Quadro 1 e discutida na sequência do texto.

Quadro 1: Dimensões analíticas da categoria Acesso aos Serviços de Saúde

\begin{tabular}{|c|c|c|c|}
\hline \multicolumn{4}{|c|}{ ACESSO AOS SERVIÇOS DE SAÚDE } \\
\hline $\begin{array}{l}\text { DIMENSÃO } \\
\text { ECONÔMICA }\end{array}$ & $\begin{array}{c}\text { DIMENSÃO } \\
\text { TÉCNICA }\end{array}$ & $\begin{array}{c}\text { DIMENSÃO } \\
\text { POLÍTICA }\end{array}$ & $\begin{array}{l}\text { DIMENSÃO } \\
\text { SIMBÓLICA }\end{array}$ \\
\hline $\begin{array}{c}\text { Equidade; } \\
\text { Racionalização; } \\
\text { Relação entre } \\
\text { oferta e } \\
\text { demanda. }\end{array}$ & $\begin{array}{c}\text { Planejamento; } \\
\text { Organização; } \\
\text { Regionalização; } \\
\text { Hierarquização; } \\
\text { Definição de fluxos; } \\
\text { Qualidade; } \\
\text { Resolubilidade dos } \\
\text { serviços de saúde. }\end{array}$ & $\begin{array}{l}\text { Políticas de saúde; } \\
\text { Conformação } \\
\text { histórica } \\
\text { do modelo de } \\
\text { atenção } \\
\text { à saúde; } \\
\text { Participação da } \\
\text { Comunidade. }\end{array}$ & $\begin{array}{c}\text { Percepções, } \\
\text { concepções e } \\
\text { atuação } \\
\text { dos sujeitos; } \\
\text { Representações sociais } \\
\text { do processo } \\
\text { saúde-doença; } \\
\text { Representações sociais } \\
\text { da forma como o } \\
\text { sistema de saúde se } \\
\text { organiza para atender } \\
\text { às necessidades. }\end{array}$ \\
\hline \multicolumn{4}{|c|}{ TOTALIDADE CONCRETA } \\
\hline $\begin{array}{l}\text { BUSCAR O } \\
\text { EQUILÍBRIO } \\
\text { NA RELAÇÃO } \\
\text { OFERTA / } \\
\text { DEMANDA }\end{array}$ & $\begin{array}{c}\text { ORGANIZAR A } \\
\text { REDE } \\
\text { ASSISTENCIAL DE } \\
\text { FORMA REGIONALIZADA } \\
\text { E } \\
\text { HIERARQUIZADA }\end{array}$ & $\begin{array}{l}\text { DESENVOLVER } \\
\text { CONSCIÊNCIA } \\
\text { SANITÁRIA E } \\
\text { ORGANIZAÇÃO } \\
\text { POPULAR }\end{array}$ & $\begin{array}{l}\text { ABORDAR AS } \\
\text { REPRESENTAÇÕES } \\
\text { SOCIAIS DA } \\
\text { ATENÇÃO } \\
\text { À SAÚDE E } \\
\text { DOS } \\
\text { SERVIÇOS } \\
\text { DE SAÚDE }\end{array}$ \\
\hline \multicolumn{4}{|c|}{ UNIVERSALIZAÇÃO DO ACESSO AOS SERVIÇOS DE SAÚDE } \\
\hline
\end{tabular}

Fonte: Jesus (2006)

As dimensões de análise da categoria acesso em busca de uma totalidade concreta teriam que ser alicerçadas no princípio da Equidade, no estabelecimento de caminhos para a universalização da atenção, regionalização, hierarquização e participação popular. Para isso é imprescindível a contribuição dos sujeitos individuais e coletivos, que se materializam na produção de novas realidades sociais para buscar maior universalidade e 
equidade: em relação oferta/demanda; em maior aproximação da realidade, na organização dos sistemas hierarquizados de atenção à saúde; em maior capacidade de emancipação com a produção de sujeitos sociais individuais e coletivos capazes de impulsionar a história na direção da transformação; e, em maior compreensão dos elementos subjetivos no momento de determinar as atividades para intervir sobre o processo saúde-doença e sobre as organizações de saúde, consideradas complexas por natureza.

\section{DISPOSITIVOS DO PLANEJAMENTO EM SAÚDE PARA BUSCAR EQUILÍBRIO NA RELAÇÃO OFERTA/ DEMANDA NO ÂMBITO DO SUS - A DIMENSÃO ECONÔMICA DO ACESSO AOS SERVIÇOS DE SAÚDE}

A relação oferta/demanda pode ser entendida como a relação existente entre a capacidade de oferecer serviços de saúde e a necessidade de assistência de uma dada população. É o pilar de sustentação da dimensão econômica aos serviços de saúde.

Aí está o desafio da planificação em saúde no Brasil: “[...] estabelecer acesso à saúde com disponibilidade, acessibilidade, adequação funcional, capacidade financeira e aceitabilidade". (GIOVANELLA; FLEURY, 1996) Quem tem acesso à saúde tem possibilidade de alcançar o trabalho e a remuneração, e, por conseguinte, aproxima-se do mercado, sendo, portanto, consumidor em potencial, co-participe das definições de fluxos mercadológicos, direcionando o raciocínio das instâncias reguladoras estatais para a produção dos serviços de assistência à saúde.

Se o desafio do SUS é garantir acesso com disponibilidade de serviços e recursos; acessibilidade; adequação funcional; capacidade financeira; e aceitabilidade por parte de trabalhadores e usuários, então o lema é desenvolver uma política de governo que, resguardada na teoria do modelo econômico, possibilite a criação de dispositivos para equilibrar a relação entre oferta e demanda, (ANDRADE, 2001) já entendendo que a ação mercadológica privilegia essa relação na sua definição.

Em que pesem os paradoxos historicamente estabelecidos neste cenário, a relação oferta/demanda tem sido utilizada por muitos planejadores do campo da Saúde Coletiva como substrato para desenvolver dispositivos 
tecnológicos capazes de superar as adversidades impostas pelo modelo neoliberal, numa luta entre concepção contra-hegemônica e prática hegemônica.

R. Campos (2003) apresenta o caráter de tensão-contradição do planejamento na discussão da sua racionalidade instrumental, explicitando uma dada crise ancorada nos paradoxos existentes entre a concepção e a prática do planejamento na década de noventa, período de consolidação do SUS. Uma visão que resgata a ação do planejamento na prática, fazendo um contraponto entre sua operacionalidade, isto é, sua razão instrumental, e sua aproximação com a realidade, entendida como dinâmica de relações entre sujeitos, teoria e prática.

O contexto do neoliberalismo instalado no Brasil propunha uma reforma liberal/produtivista - um modelo de reforma da Seguridade Social baseada numa lógica competitiva de mercado - para o sistema de saúde, a exemplo do processo de reforma da Previdência Social; uma contraposição à consolidação do SUS, um modelo universal/publicista de reforma previdenciária instaurado no Brasil com o processo de redemocratização ocorrido entre 1975 e 1992, desenvolvido no processo de transição e consolidação democrática, cujas diretrizes apontavam para a universalidade e equidade no acesso da população aos serviços de saúde, que deveriam se organizar, sob a tutela do Estado, para garantir integralidade da atenção à saúde. (FLEURY, 1996)

Um estudo que trata da relação entre demanda e oferta foi realizado por C. Campos (1993) e diz respeito à importância dos inquéritos epidemiológicos em saúde, enquanto possibilidades de monitoramento da disponibilidade de serviços e recursos, da acessibilidade, da acomodação ou adequação funcional dos serviços, da capacidade financeira e da aceitabilidade dos usuários. Os inquéritos de saúde possuem uma ação demandante sobre os serviços e servem para detectar necessidades invisíveis, geralmente não explicitadas pelos usuários, no momento que procuram os serviços de saúde para um atendimento convencional, seja uma consulta ou um simples procedimento de prevenção.

As demandas invisíveis possivelmente detectadas através dos inquéritos epidemiológicos seriam elementos que subsidiariam o planeja- 
mento, a programação, a orçamentação e a avaliação dos sistemas e serviços de saúde. Serviriam para auxiliar o processo de planejamento, podendo facilitar a adequação da oferta dos serviços à prevalência dos problemas de saúde autorreferenciados, de forma a garantir maior aporte aos recursos disponíveis, enquanto novos investimentos atingem o aumento da disponibilidade de serviços. (CAMPOS, 1993)

Em que pese à visão economista enraizada na discussão da relação oferta/demanda, o desafio dos planejadores está posto no momento em que se assume que as práticas do cotidiano nessa relação devem estar pautadas no paradigma da integralidade, enquanto a ação social resultante da permanente interação de atores, em planos distintos de atenção à saúde (individual e coletiva), nos quais os aspectos subjetivos e objetivos sejam considerados. (PINHEIRO, 2001)

\section{ORGANIZAÇÃO HIERAROUIZADA DE REDES DE ATENÇÃO COMO DISPOSITIVO DO PLANEJAMENTO EM SAÚDE PARA VIABILIZAR O ACESSO AOS SERVIÇOS NO SUS: UMA DIMENSÃO TECNO- ASSISTENCIAL}

A organização de uma rede hierarquizada de serviços é um dos dispositivos do planejamento para viabilizar o acesso da população aos serviços de saúde. Assenta-se sobre o "modelo sanitarista-planificador", que tem como princípios fundamentais a regionalização e a hierarquização da rede de serviços de saúde, com vistas a estabelecer universalidade, equidade e integralidade.

A regionalização remonta experiências internacionais, como as desenvolvidas na Inglaterra, o "Sistema Dawson", com o sistema de saúde do tipo universal, criado na década de vinte, que tinha as seguintes bases territoriais: definição de população alvo; organização da rede assistencial de acordo com níveis de complexidade; a noção de porta de entrada; e a existência de mecanismos de referência. (KUSHNIR, 2006)

Na União Soviética e países socialistas europeus havia o "Sistema Semashko", que adotava a mesma lógica operacional do sistema inglês, diferenciando-se apenas pelo fato de seu financiamento ter sido feito dire- 
tamente pelo Estado, de modo centralizado e com alto grau de normatização. (KUSHNIR, 2006)

Já a Alemanha tinha o "Sistema Bismark", que introduziu a lógica do seguro social, que determinava que o ingresso aos serviços de saúde estivesse na dependência de uma vinculação formal dos usuários ao sistema de empregos. (KUSHNIR, 2006)

A regionalização e a hierarquização sempre estiveram na base das propostas de reorganização do sistema de saúde brasileiro, ainda nos primórdios da organização da assistência à saúde na década de vinte, com o desenvolvimento dos serviços previdenciários; ou com a luta pela reforma sanitária, desencadeada a partir da década de setenta. Tiveram sua introdução nos conceitos norteadores do SUS com a Constituição de 1988 e sua concretização a partir da divulgação da Norma Operacional da Assistência à Saúde (NOAS), em 2001. (BRASIL. Ministério da Saúde, 2002)

Sob os auspícios da regionalização enquanto princípio, se desenvolveram no Brasil conceitos como: níveis de complexidade da atenção, referência, contrarreferência, população referenciada, dentre outros, que servem para orientar a discussão dos processos integrados de gestão e propiciar atendimento em saúde com resolubilidade em unidades de diferentes perfis assistenciais, organizadas de forma hierárquica, num contexto de acomodação da densidade tecnológica, aliada à disponibilidade, acessibilidade, aceitabilidade e capacidade financeira de captação de novas tecnologias.

Toda formatação do processo de regionalização e hierarquização na era SUS vem sendo desenvolvido com base na apresentação da dimensão organizativa dos modelos assistenciais, com vistas ao estabelecimento de relações hierárquicas entre unidades de produção de serviços nos níveis de complexidade tecnológica. A organização hierárquica estabelecida numa microrregião de saúde (BRASIL. Ministério da Saúde, 2002) possibilita, então, a criação de possibilidades de alcançar uma gama variada de ações e serviços que, de outro modo, não poderiam ser garantidos à população.

O campo da Saúde Coletiva trata a questão do planejamento e dos seus dispositivos para organizar a rede, engendrada à discussão dos modelos tecno-assistenciais, observando sua conformação e organização, seus 
fluxos, seus programas e as possibilidades de reorganização, para garantir o acesso dos usuários com universalidade, equidade e integralidade. Parte-se de ponderações teórico-conceituais até o desenvolvimento de estratégias de organização de redes assistenciais, avançando, inclusive, para a avaliação de resultados, se utilizando de metodologias participativas, incluindo os diversos sujeitos no processo de discussão.

A hierarquização dos serviços e sua disposição em rede é um processo que está em construção no Brasil. As redes assistenciais se constituem num conjunto de unidades de diferentes perfis e funções, organizadas de forma articulada, responsáveis pela provisão integral dos serviços de saúde numa dada região, entendida como a base territorial e populacional que tem autossuficiência até o nível de complexidade definido, englobando a estrutura geopolítica do País, Estado, das cidades, ou de uma única cidade ou parte da mesma, reservadas as especificidades e peculiaridades de cada realidade. (KUSHNIR, 2006)

A relação entre as unidades assistenciais de uma rede de serviços deve se dar com o estabelecimento de mecanismos de referência e contrarreferência, o que é premissa para a determinação das linhas de cuidado na busca da integralidade assistencial. Neste sentido, a questão do acesso assume um caráter regulador sobre o sistema de saúde, definindo fluxos, funcionamento, capacidade e necessidade de expansão e organização da rede para o cuidado progressivo ao usuário, impulsionando o planejamento da saúde na direção da dimensão cuidadora horizontal defendida no modelo do círculo, apresentado por Cecílio (1997).

Ressalta-se um estudo realizado sobre o panorama atual da atenção aos defeitos congênitos no Brasil que toma como base de análise os documentos oficiais do Ministério da Saúde e dados levantados nos sistemas de informações sobre mortalidade e internações hospitalares. (HOROVITZ; LLARENA JUNIOR; MATTOS, 2005) A partir do levantamento da situação inicial, confrontando dados oficiais de diagnóstico das deformidades com os dados relativos à oferta de serviços assistenciais, distribuição geográfica dos mesmos e suas características de atendimento, os autores discutiram o impacto dos defeitos congênitos sobre o sistema de saúde, as ações governamentais disponíveis para enfrentamento desses problemas e pro- 
puseram, com base no material condensado, a elaboração de uma política de saúde voltada para a problemática, corroborando, assim, com a ideia de sistematização de redes assistenciais regionalizadas e hierarquizadas para atenção a essa população específica.

\section{DISPOSITIVOS DO PLANEJAMENTO PARA O DESENVOLVIMENTO DA CONSCIÊNCIA SANITÁRIA E DA ORGANIZAÇÃO POPULAR NO ÂMBITO DO SUS: A DIMENSÃO POLÍTICA DO ACESSO AOS SERVIÇOS DE SAÚDE}

Giovanella e Fleury (1996), inspiradas em Berlinguer (1978), definem "consciência sanitária" como a tomada de consciência de que a saúde é um direito da pessoa e um interesse da comunidade, sendo necessária uma ação individual e coletiva para alcançá-la. Trata-se de um componente cognitivo através do qual a população compreende a determinação social do processo saúde/doença, e, da mesma forma, os fatores que determinam a organização social das práticas de saúde. A construção do acesso nesse sentido se dá pela participação cidadã e pelo controle social, que intervém sobre o sistema de saúde e sobre as práticas de trabalho e de gestão.

Testa (1997), por sua vez, discute "consciência sanitária" no contexto de suas reflexões sobre o pensamento estratégico, remontando a questão da prática médica, sua evolução histórica. Para tanto, propõe a necessidade de se imprimir uma lógica democrática a essa prática, superando a falsa consciência, desarticulada da realidade objetiva e da contextualização histórica da vida cotidiana.

G. Campos (1992) coaduna com as impressões e considerações de Testa (1997) acrescentando que a superação do paradigma autoritário seria possível, no momento em que houvesse uma profunda unidade entre a construção do conhecimento e da prática social dos homens, como resultado do desenvolvimento das forças produtivas, dos saberes e da ordem política e ideológica. Nesse sentido, culminaria com a ampliação dos direitos sociais, a instauração de níveis progressivos de cidadania e a participação de contingentes populacionais, cada vez mais amplos nos esquemas de poder e de governo, da vida e da sociedade. 
A "consciência sanitária” também nos remete à (des) alienação, conceito trabalhado tanto por Giovanella e Fleury (1996), quanto G. Campos (2000), explicitando-o como produção de sujeitos transformados socialmente e capazes de transformar realidades. Nesse contexto, evidenciam-se os aspectos desta dimensão do acesso, tratando da questão da organização popular e do controle social como elementos de transformação política.

Partindo do princípio que a entrada nos serviços de saúde está entrelaçada por elementos históricos que sempre o conduziram a uma situação de dominação, ante as condições socioeconômicas, a democracia lança mão dos seus dispositivos para fomentar na sociedade a organização popular e o controle social para garantir e consolidar este ingresso. Um movimento de reconquista, tendo em vista o contexto privatizante que o modelo neoliberal impõe aos serviços de saúde e à sua lógica de organização.

A dimensão política do acesso aliada aos seus aspectos de consciência cidadã e organização popular reflete a intenção de se fazer uma revolução pacífica na relação oferta/demanda e uma indução à constituição de redes assistenciais capazes de darem conta do passivo social em saúde instalado no país, tendo a integralidade como eixo condutor das práticas de saúde e como paradigma assistencial predominante no momento do planejamento dos serviços.

É no bojo da discussão dessa dimensão que se institui o controle social, enquanto definidor do acesso à saúde num processo histórico, que, partindo do reconhecimento da realidade, busca superar a racionalidade hegemônica imposta pela dominação do Estado sobre a sociedade, conduzindo a um redirecionamento processual, com a instalação de uma nova realidade, calcada no controle da sociedade sobre o Estado sob os auspícios da democracia.

Neste sentido, Assis (2003) afirma que o controle social não pode ser tratado como forma do Estado manter a ordem e coesão social em torno de um projeto hegemônico, mas sim a participação efetiva da sociedade sobre as ações do Estado. A participação social não seria entendida apenas como uma extensão burocrática e executiva, mas como um processo contínuo de democratização e de produção de sujeitos com maior autonomia. Processo que, segundo a autora, está em construção nos espaços institucionais do SUS. 
Essa "maior autonomia" identificada por Assis (2003) coaduna com a ideia de (des) alienação discutida por G. Campos (2000), sendo, portanto, o ponto de conexão entre a ação política para a transformação dos sujeitos e a prática para implementar um processo de mudanças, corroborando novamente com a concepção de superação do paradigma do autoritarismo, que se expressa no momento em que se atinge o patamar de consciência sanitária social plena - uma utopia a ser alcançada.

Os conselhos de saúde e as demais instâncias de controle, participação e organização social se configuram, no arcabouço institucional do SUS, como o estratagema para o enfrentamento da dominação hegemônica neoliberal, da alienação dos sujeitos e dos coletivos, nos espaços institucionais na busca dessa consciência sanitária social plena.

Cecílio (1997), ao discorrer sobre os modelos tecno-assistenciais em saúde no tocante à sua conformação hipotética quanto aos fluxos dos usuários, apresenta o "modelo círculo" como estratégia para qualificar as portas de entrada, a fim de que se possam alcançar espaços privilegiados de acolhimento, vínculo e responsabilização no cuidado com a saúde, individual e coletiva. Para chegar a essa imagem-objetivo, propõe a construção de protocolos assistenciais e a adscrição da clientela como instrumentos técnicos de reorganização dos fluxos, e também destaca a necessidade de se estabelecerem os vínculos provisórios como tecnologias leves de revolução tecnológica dos processos de trabalho, o que, por si só, se caracteriza como uma ação (des) alienante dos trabalhadores nas portas de entrada do sistema.

Discutir a dimensão política do acesso, portanto, é discutir a construção de sujeitos políticos, politizados, militantes e (des) alienados. Livres para decidir acerca de seu destino com autonomia e consciência social, construídas sob os auspícios de um novo paradigma sanitário, pautado nos princípios da universalidade, da equidade e da integralidade na saúde. 
DISPOSITIVOS DO PLANEJAMENTO PARA ABORDAR AS REPRESENTAÇÕES SOCIAIS DA ATENÇÃO À SAÚDE E DOS SERVIÇOS DE SAÚDE: A DIMENSSÃO SIMBÓLICA DO ACESŞO - UMA UTOPIA A SER ALCANÇADA

Tratar da dimensão simbólica do acesso, segundo Giovanella e Fleury (1996), nos remete à discussão acerca do modelo das representações sociais. Seria assumir a realidade enquanto mediada pela ordem simbólica que é determinada pela intersubjetividade de cada indivíduo no conjunto das suas relações e representações junto à sociedade. Os sujeitos coletivos dão lugar aos sujeitos históricos, que, por sua vez, se conformam em sujeitos sociais, coletivamente determinados pelas suas representações. A produção das ideias, das representações, da consciência, está intimamente relacionada à realidade material e espiritual de cada sujeito na sua dimensão coletiva.

Minayo (2004), ao definir representações sociais, apresenta as características intersubjetivas como indissociáveis da realidade, haja vista estarem relacionadas ao pensamento, à ação e ao sentimento. Mas também alerta que a natureza que se deve considerar ao estudar as representações sociais não é a individual, e sim a societal. Isto é, a natureza societal diz respeito a sentimentos exteriores aos indivíduos e esses são dotados de um poder coercitivo em que se lhes impõe. Alerta também que o caráter coletivo das representações sociais aproxima-as do senso comum e revela seu potencial transformador, haja vista ser permeado pelas constantes lutas classistas e pelo confronto entre hegemonia e contra-hegemonia.

No tocante às representações sociais de saúde e doença, Minayo (2004) apresenta o processo saúde/doença como resultado da expressão social e individual e das contradições sociais. A saúde é identificada como representação do campo das lutas políticas. Essas considerações fundamentam a ideia do componente simbólico enquanto definidor do acesso, pois, a depender das concepções sobre a saúde, a doença e o processo saúde/doença, podem ser planejados caminhos diferentes de intervenção para garantir a entrada do usuário no sistema de saúde. 
Cecílio $^{19}$ trabalha com o simbólico, com o percebido, para identificar contradições e caracterizar novas formas de se fazer saúde - da pirâmide ao círculo. Discute também o simbólico, quando trata da questão da porta de entrada do sistema como um espaço ambíguo, permeado pelos interesses dos diversos sujeitos que por ele transitam e que nele atuam. Outrossim, apresenta um outro olhar sobre essa dimensão quando discute os vínculos provisórios, enquanto um sistema de relações intersubjetivas capaz de promover acolhimento e responsabilização.

Sá (2001), ao discutir a subjetividade e sua relação com os projetos coletivos, apresenta a questão do mal-estar nas organizações como um componente simbólico que interfere nos processos intersubjetivos e grupais e nos processos de planejamento e gestão. A dinâmica das relações entre as pessoas, os grupos e as organizações em geral, corroboram com a fantasia coletiva, um constituinte simbólico que, caracterizado pelas dimensões culturais, subjetivas e inconscientes dos sujeitos no cotidiano das organizações contribuem para a construção de projetos coletivos e de governabilidade.

A dimensão simbólica do acesso aos serviços de saúde, entendida a partir das representações sociais da atenção à saúde e dos serviços, revelam, portanto, uma tensão-contradição entre a realidade subjetiva e a realidade concreta dos sujeitos em ato, estabelecida como um divisor de águas para discuti-lo, no tocante às dimensões específicas da acessibilidade, disponibilidade, adequação funcional, capacidade financeira e aceitabilidade. Trata-se de uma concepção ampliada do processo saúde/doença, complementada por elementos econômicos, técnicos, políticos, sociais e antropológicos, que reforçam o papel dos sujeitos e de suas representações, sem, contudo, minimizar a capacidade transformadora da práxis e do senso comum.

O que se percebe no âmbito do SUS é um volume importante de tentativas em operacionalizar proposições que dêem conta dessa dimensão do acesso aos serviços de saúde, explicitadas através das diversas políticas que aproximam o senso comum das práticas, a exemplo do Programa de Saúde da Família (PSF), dos Centros de Atenção Psicossocial e de outros serviços integrados às políticas públicas na área de saúde. Outrossim, a Po- 
lítica de Educação Permanente em Saúde e a Educação Popular corroboram com a ideia de aproximação responsável entre senso comum e práticas de saúde na sua dimensão simbólica, sempre mediados por práticas pedagógicas.

O PSF, apesar de sua normatividade, se tomado como exemplo, configura-se como espaço percebido de aproximação e interação simbólica importante, pois permite programar a horizontalização das relações entre trabalhadores e usuários, formalizando vínculos, que, segundo Cecílio (1997), trabalham a construção e as agendas de saúde mais próximas do ideário coletivo local.

Por fim, o planejamento em saúde assume um desafio importante no momento em que considera a dimensão simbólica como componente da realidade a ser trabalhada. Conhecer a visão de mundo, as concepções, as ideias, as aspirações, as metáforas e os desejos de uma sociedade; compreender a realidade histórica, a relação de dominância e subordinação, a conjuntura sócio-econômica e ideológica de uma sociedade; e perceber a organização política em torno do jogo de interesses contraditórios entre dominantes e dominados e seus reflexos sobre a consciência social, se conformam apenas como dispositivos do complexo instrumental que os sujeitos do planejamento devem utilizar para alcançar a magnitude da abordagem proposta nessa dimensão.

\section{CONSIDERAÇÕES FINAIS}

O planejamento em saúde assume um desafio importante no cotidiano do sistema e dos serviços de saúde. Neste sentido, ao se discutir a categoria "acesso aos serviços de saúde" e as contribuições do planejamento para sua construção no âmbito do SUS, adota-se como eixo central discursivo a conexão entre teoria e prática do planejamento no campo da Saúde Coletiva, relacionada às diferenças: econômica, tecno-assistencial, política e simbólica, retratadas pelos teóricos da área. As dimensões evidenciam a contribuição dos sujeitos/atores sociais na busca de uma maior aproximação com a realidade de saúde do país, tanto na compreensão dos elementos simbólicos que determinam as intervenções do processo saúde-doença, quanto nas diferentes formas de organização do sistema e dos 
serviços de saúde, bem como das políticas, percebidas em seus componentes (políticos, econômicos e tecno-assistenciais), que determinam o processo de produção do cuidado.

\section{REFERÊNCIAS}

JESUS, W. L. A. Re-significação do planejamento no campo da saúde coletiva: desafios teóricos e busca de novos caminhos. 2006. 235 f. Dissertação (Mestrado em Saúde Coletiva). Departamento de Saúde, Universidade Estadual de Feira de Santana, Feira de Santana-BA.

ALBUQUERQUE J. A. G. Instituição e poder: a análise concreta das relações de poder nas instituições. 2. ed. Rio de Janeiro: Graal, 1986.

ANDRADE, L. O. M. SUS passo a passo: normas, gestão e financiamento. São Paulo: Hucitec, 2001.

ASSIS, M. M. A. O processo de construção do controle social no Sistema Único de Saúde e a gestão nos espaços institucionais. Saúde em Debate, Rio de Janeiro, v. 27, n. 65, p. 324-335, 2003.

ASSIS, M. M. A; VILLA, T. C. S; NASCIMENTO, M. A. A. Acesso aos serviços de saúde: uma possibilidade a ser construída na prática. Ciên. Saúde Col., Rio de Janeiro, v. 8, n. 3, p. 815-823, 2003.

BERLINGER, G. Medicina e política. São Paulo: Hucitec, 1978.

BRASIL. Ministério da Saúde. Norma operacional de Assistência à saúde/ SUS - NOAS 01/02. Brasília: Ministério da Saúde, 2002.

CAMPOS, C. E. A. Os inquéritos de saúde sob a perspectiva do planejamento. Cad. Saúde Públ., Rio de Janeiro, v. 9, n. 2, p. 190-200, 1993.

CAMPOS, G. W. S. Um método para análise e co-gestão de coletivos. São Paulo: Hucitec, 2000.

. Reforma da reforma: repensando à saúde. São Paulo: Hucitec, 1992.

CAMPOS, R. O. O planejamento no labirinto: uma viagem hermenêutica. São Paulo: Hucitec, 2003.

CECílIO, L. C. O. Modelos tecno-assistenciais em saúde: da pirâmide ao círculo, uma possibilidade a ser explorada. Cad. Saude Publ., Rio de Janeiro, v. 13, n. 3, p. 469-478, 1997.

FLEURY, S. Paradigmas da reforma da Seguridade Social: liberal-produtivista versus universal-publicista. In: EIBENSCHUTZ, C, (Org.). Política de saúde: o público e o privado. Rio de Janeiro: Fiocruz; 1996. p. 69-94. 15. 
GIOVANELLA, L.; FLEURY, S. Universalidade da Atenção à Saúde: acesso como categoria de análise. In: EIBENSCHUTZ, C. (Org.). Política de saúde: o público e o privado. Rio de Janeiro: Fiocruz; 1996. p. 177-198.

HOROVITZ, D. D. G; LLARENA JUNIOR, J. C; MATTOS, R. A. Atenção aos defeitos congênitos no Brasil: panorama atual. Cad. Saude Publ., Rio de Janeiro, v. 21, n. 4, p. 1055-1065, 2005.

HOUAISS, A. Dicionário Houaiss de língua portuguesa. Rio de Janeiro: Objetiva, 2001.

KUSHNIR, R. Organizando redes de serviços de saúde. In: PESSÔA, L. R, PINTO, L. F. Curso de Aperfeiçoamento em gestão de investimentos e projetos em saúde. Rio de Janeiro: Fiocruz, 2006. p. 96-111.

MINAYO, M. C. S. O desafio do conhecimento: pesquisa qualitativa em saúde. 8. ed. São Paulo: Abrasco, 2004.

PINHEIRO, R. As práticas do cotidiano na relação oferta e demanda dos serviços de saúde: um campo de estudo e construção da integralidade. In: PINHEIRO, R; MATTOS, R. A (Org.). Os sentidos da integralidade na atenção e no cuidado à saúde. Rio de Janeiro: Abrasco, 2001. p. 65-112

PUSTAI O. J. O sistema de Saúde no Brasil. In: DUNCAN, B. B; SCHMIDT, M. I; GIUGLIANI, E. R. J (Org.). Medicina ambulatorial: condutas de atenção primária baseadas em evidências. 3. ed. Porto Alegre: Artmed; 2004.

SÁ, M. C. Subjetividade e projetos coletivos: mal-estar e governabilidade nas organizações de saúde. Ci. Saude Col., Rio de Janeiro, v. 6, n.1, p. 151-164, 2001.

SANTOS, B. S. Introdução a uma ciência pós-moderna. 4. ed. Rio de Janeiro: Graal, 2003.

TESTA, M. Saber en salud: la construcción del conocimiento. Buenos Aires: Lugar Editorial, 1997. 



\section{CAPÍTULO 5}

\section{Planejamento em saúde e poder: dimensões teóricas de análise ${ }^{1}$}

Washington Luiz Abreu de Jesus

Marluce Maria Araújo Assis

Não se trata de libertar a verdade de todo sistema de poder - o que seria quimérico na medida em que a própria verdade é poder - mas se desvincular o poder da verdade das formas de hegemonia (sociais, econômicas, culturais) no interior das quais ela funciona no momento [...].

Foucault, 1986.

\section{INTRODUÇÃO}

Discutir poder enquanto categoria analítica do planejamento em saúde é no mínimo instigante. O desafio posto é apresentar uma nova abordagem, já que o tema já foi deveras explorado e, no nosso caminhar metodológico, encontramos o poder entendido enquanto capacidade de intervir sobre a realidade. Neste sentido se estabelece um desafio conceitual, pois é necessário re-significar o poder e re-dimensionar o caráter da intervenção sobre a realidade, já que, na arena das discussões sobre o objeto, identificamos que o poder aliado ao planejamento está relacionado a componentes técnicos, políticos e administrativos articulados entre si na atuação dos sujeitos nas organizações de saúde.

Para dar suporte a este caminhar teórico e conceitual, nos apoiamos nos trabalhos de Testa $(1997,2004)$ e Foucault (2003), haja vista que esses autores assumem o poder enquanto uma categoria de análise e uma estrutura epistemológica complexa; tendo aportes de Albuquerque (1986),

1 Agradecimento dos autores a Chaider Gonçalves Andrade e Sisse Figueredo de Santana pelas contribuições na revisão final do texto deste capítulo. 
Giovanella e Fleury (1996), Campos (2000), Bobbio (2000), Pereira (2003) e Sargentini e Navarro-Barbosa (2004). Entendemos que esses autores contribuem para analisar os diversos meandros teórico-conceituais do poder para alcançar uma totalidade histórica, ainda que parcial, num movimento de articulação entre os pensamentos desses autores e as evidências da produção científica da área.

Testa (1997) discute que todo "poder" tende a uma convivência entre o equilíbrio e a desigualdade dada pela correlação das forças organizativas de uma sociedade: as relações externas, o saber, a prática, os sujeitos, os conhecimentos empíricos e científicos, as práticas hegemônicas, a dominação e a significação social das formas de poder. Todos esses elementos, cujos propósitos são a legitimação, a mudança e o crescimento de um status de poder, confluem para a conformação do espaço de decisão e se materializam através das tipologias temporais e objetivas do poder, identificadas por Testa como administrativas, cujos recursos organizam a gestão; técnicas, cujos recursos organizam a produção; e políticas, cujos recursos organizam a conjuntura. Essas tipologias serão discutidas adiante.

Michel Foucault (2003), por sua vez, discute poder numa perspectiva intimamente ligada à subjetividade e ao discurso. Para ele, o poder é um corpo social multidirecional, espalhado como micropoderes e resultante da produção de indivíduos preparados racionalmente para o exercício do poder. O saber e o conhecimento são o pano de fundo para o jogo e a disputa pelo poder e seu espaço de validação é o campo das práticas e da produção de tecnologia desenvolvido pela sociedade. (SARGENTINI; NAVARRO-BARBOSA, 2004)

Para Foucault (2003), a função do Estado é regulatória e se dá por meio do que ele denomina "bio-poder", uma categoria de racionalidade estatal e controle sobre os indivíduos que tem a questão da disciplina como princípio fundamental. O Estado, então, através do seu poder, regula a vida dos indivíduos e controla suas subjetividades através do jogo disciplinador.

Um diálogo teórico entre Testa e Foucault nos permite perceber quão complexa é a análise desta questão e quão sublime é a possibilidade de compreensão que temos quando nos desvelamos enquanto sujeitos na busca do conhecimento acerca desse tema. O quadro que se segue (QUADRO 
01) sintetiza as visões de Mário Testa (1995) e Michel Foucault (2003), explicitando como esses autores concebem o poder com relação ao Estado, ao tempo, ao espaço, aos recursos, à política, à técnica, à produção e ao sujeito.

Com base neste quadro síntese, nos propusemos a estabelecer o diálogo teórico entre esses autores, articulando suas ideias aos conteúdos explicitados na produção científica que compõe a base bibliográfica do estudo que deu origem a esse livro. Em que pesem as possíveis diferenças de perspectivas, esses teóricos dão uma importante contribuição para a discussão do poder no campo da saúde, revelando dimensões que vão desde a realidade subjetiva até a realidade objetiva e concreta.

QUADRO 01: 0 "poder" nas visões de Mário Testa e

Michel Foucault

\begin{tabular}{|l|c|c|}
\hline Estado & MÁRIO TESTA & MICHEL FOUCAULT \\
\hline Tempo / espaço & $\begin{array}{c}\text { Legitimado pela violência e pela } \\
\text { força }\end{array}$ & $\begin{array}{c}\text { Regula a vida por meio da } \\
\text { disciplina }\end{array}$ \\
\hline Recursos & $\begin{array}{c}\text { Administrativo, técnico, político, } \\
\text { real e virtual }\end{array}$ & $\begin{array}{c}\text { O tempo e o espaço são } \\
\text { indizíveis, indivisíveis e } \\
\text { invisíveis }\end{array}$ \\
\hline Política & $\begin{array}{c}\text { Técnicos, políticos e } \\
\text { administrativos }\end{array}$ & $\begin{array}{c}\text { Saber, discurso e } \\
\text { subjetividade }\end{array}$ \\
\hline Técnica & Conjuntura social & Conjuntura intersubjetiva \\
\hline Produção & Resultado das relações sociais & $\begin{array}{c}\text { Síntese dos micropoderes } \\
\text { produtores }\end{array}$ \\
\hline Sujeito & Componente do espaço de poder & $\begin{array}{c}\text { Verdade formada a partir } \\
\text { do poder }\end{array}$ \\
\hline
\end{tabular}

No tocante à relação Estado/Poder, Testa (1995) discute o poder como uma espécie de "violência" institucionalizada para a manutenção do status quo, ao passo que Foucault ${ }^{3}$ discute o Estado como regulador da sociedade por meio do poder disciplinador e da racionalidade. Compreendemos que para alcançar a plenitude do poder, o Estado deve se municiar de instrumentos de legitimação para controlar as relações sociais e se instituir enquanto Estado. 0 poder disciplinador e a racionalidade são o substrato da 
institucionalização de certa "violência", que aqui não é entendida de forma restrita como uso da força, e sim como aplicação de uma força simbólica sobre a sociedade.

Giovanella (1990) discorre sobre a questão do poder apresentada por Testa, fazendo uma análise a partir da relação entre Estado, política e sociedade. Resgata as concepções de Estado apresentadas ao longo da história e da filosofia, culminando com a ideia de que o poder na sociedade se estabelece nas relações de produção e na divisão social do trabalho; nas relações de luta, de controle e de sujeição, num contexto de desigualdades e conflitos.

[...] o poder é relação social que, na sociedade dividida em classes, tem seus fundamentos nas relações de produção e na divisão social do trabalho. Exerce-se na sociedade política/aparelhos de Estado e na sociedade civil/aparelhos privados de hegemonia, conformando um Estado ampliado, resultado da condensação de uma relação de forças entre classes e frações de classes [...]. (GIOVANELLA, 1990)

Em relação ao tempo e ao espaço, Testa (1995) define o tempo como político, técnico e administrativo; real e virtual. O tempo político é o tempo de uma conjuntura; o tempo técnico é o tempo de uma ação; e o tempo administrativo é o tempo de uma gestão. O espaço, para Testa, é lócus da decisão. Sargentini e Navarro-Barbosa (2004), inspirados em Foucault (2003), por sua vez, verificam que o tempo e o espaço são indizíveis, indivisíveis e invisíveis, sendo, portanto, uma impressão subjetivamente constituída.

No tocante à relação tempo/espaço, podemos adotar diversas percepções, dependendo do ângulo de visão que temos sobre a questão. Se analisarmos essa relação a partir do ponto de vista da prática, há uma relação com as ideias de Testa, já que é necessário sistematizar os momentos para se ter mais clareza na tomada de decisão. Porém, se adotarmos uma visão mais intimista e totalizadora, não alcançaremos os limites da divisão conceitual entre o tempo e o espaço, pois ambos são simultâneos e concorrem para a concretização da história.

Os recursos do poder, segundo Testa (1995), se dividem em administrativos, entendidos como recursos burocráticos; técnicos entendidos 
como recursos de conhecimento; e políticos, entendidos como recursos de mediação. Foucault, de acordo com as abordagens de Sargentini e Navarro-Barbosa (2004) e Pereira (2003), por sua vez, define que os recursos do poder são o saber, o discurso e a subjetividade, elementos explorados nos espaços de controle das representações de uso da linguagem e da mídia.

Compreendemos a visão de Testa (1995), mas não devemos deixar de destacar a inovadora percepção de Foucault (2003), quando identifica os espaços de expressão da linguagem como recursos do poder. Trata-se de uma concepção moderna e atual, que sinaliza a importância que tem a mídia na formação do componente simbólico do poder no mundo da vida. O saber é um substrato para a construção de discursos subjetivos que, dependendo da sua expressão, pode se transformar em mito ou verdade.

Giovanella (1990) faz uma re-interpretação do trabalho de Foucault, considerando que o poder-saber fundamenta o poder técnico e que o saber só é saber, se dotado de poder. $O$ saber é verdade, e verdade é poder. Portanto, no mundo da vida, os recursos do poder, para se estabelecerem, passam pelo campo do saber e se manifestam enquanto capacidades e verdades, o que a autora denomina poder-capacidade e poder-relação.

R. Campos (2000), ao abordar a questão dos dilemas meios-fins e controle-subjetivação do planejamento em saúde, coaduna com a afirmação de Giovanella ${ }^{11}$, acrescentando que para se apreender o sentido social, histórico e humano das capacidades e das práticas, é necessário articular criticamente o "saber-como", o "como-fazer" e "o que fazer", sem, entretanto, apagar as identidades dos sujeitos.

A relação entre poder e política, na concepção de Testa (1995), depende de uma conjuntura social, sendo o poder consequente à política. Para Foucault (2003), entretanto, a política é consequente ao poder e depende da subjetividade. Identificamos o caminho que trata da macropolítica, tendo o poder como categoria central no campo da saúde, adotado por Testa; e o caminho que trata da macroestrutura e da micropolítica, trabalhado por Foucault. Em síntese, o poder e a política se entrelaçam nos sentidos macroestrutural, macropolítico e micropolítico, e, dependendo do ponto de partida para a sua análise, o foco da política estará sobre a conjuntura ou sobre o sujeito. 
Para tratar dessa questão, Giovanella (1990) resgata a questão da ideologia enquanto um saber que é político, é concepção da realidade e prática que constrói os seus sujeitos. Também a identifica como o conjunto de ideias em relação ao sistema social que visa orientar os comportamentos políticos coletivos. A política é, portanto, uma situação social determinada pelo processo dialético dos conflitos entre os sujeitos, as estruturas e as superestruturas, fatos inerentes às contradições da realidade social concreta.

Poder e técnica, segundo Testa (1995), se relacionam através dos acúmulos de conhecimento, sendo, portanto, o saber um elemento de fortalecimento do poder. Foucault, na percepção de Sargentini e Navarro-Barbosa (2004), identifica que os saberes são acúmulos que se estabelecem para fortalecer as lutas pelo poder.

Testa apresenta o saber como elemento para fortalecer o poder e Foucault o apresenta enquanto componente de luta. O ideal libertário do saber está mais relacionado ao que está posto por Foucault. A questão da subjetividade se revela na luta pelo poder, sendo um elemento importante na construção de um cenário de disputas.

A relação poder/sujeito é discutida por Testa (1995) no entendimento que os sujeitos são componentes dos espaços de materialização do poder, assumindo posições ora de receptor, ora de emissor de ações para as mudanças conjunturais. Foucault, segundo Sargentini e Navarro-Barbosa (2004), identifica que o sujeito é uma verdade formada a partir do poder, sendo, portanto, produto concreto da sua ação enquanto corpo existencial no campo do conhecimento e do saber. Os sujeitos e sua relação com o poder assumem, nessas perspectivas, uma dimensão objetiva, que relaciona emissor e receptor; e outra relação subjetiva, que relaciona sujeito a sujeito através do artificio do saber.

Na dimensão objetiva, a relação entre os sujeitos e o poder, em que pesem a dominação e a subordinação, se configura numa relação de disputas, fato que ocorre concretamente quando ambos os sujeitos, emissor e receptor, são ativos. Não há, portanto, relação entre poder e sujeitos sem luta entre a hegemonia e a contra-hegemonia. A perspectiva adaptada na dimensão subjetiva salienta que o artifício do saber não pode se distanciar 
da prática, já que as relações de poder são permeadas pelas relações intersujeitos.

Entretanto, Giovanella (1990) pontua que o poder não pode ser visto somente no sentido negativo, pois também apresenta a capacidade de disciplinar e adestrar o corpo, num processo consentido, produzindo o indivíduo. 0 poder pode ser definido, segundo ela, como um exercício de micropoderes, organizados em redes mais ou menos hierárquicas, onde cada indivíduo é centro de transmissão de poder e se coloca como um sujeito de luta pela manutenção da hegemonia ou pela sua destituição.

Tanto para Testa(1995) quanto para Foucault (2003), o poder se organiza através da combinação do saber, da prática e do sujeito. Testa trabalha na dimensão macropolítica e identifica o poder como produto de relações sociais estabelecidas no jogo político, enquanto Foucault como a síntese dos micropoderes produtores nas dimensões macroestrutural e micropolítica, onde cada sujeito é individualmente uma esfera de poder em relação com os outros e estabelece níveis de produção, cujos produtos concretos da síntese do trabalho coletivo são construídos individualmente e impactam na constituição da sociedade.

Para finalizar este diálogo, ainda que provisoriamente, através do qual procuramos estabelecer um movimento dialético de síntese de diferentes concepções em busca de uma compreensão de uma dada totalidade parcial, percebemos que para Testa o poder é tudo - é necessário ter poder para manter ou transformar a realidade. Para Foucault, tudo é poder - o homem, na sua completude, se constitui na síntese axiológica do poder.

À luz das considerações de Testa (1995) e Foucault (2003), portanto, identificamos o poder como uma capacidade dos sujeitos para atuar sobre as realidades, sejam elas objetivas ou subjetivas, mantendo-as ou transformando-as conforme seus axiogramas ${ }^{2}$ e necessidades socialmente determinadas.

20 termo "axiograma" refere-se a uma autodeclaração de valores e antivalores, numa perspectiva práxica. (HOUAISS, 2001) 


\section{AS DIMENSÕES ANALÍTICAS DO PODER}

O poder é um elemento da prática social que dá suporte às relações que permeiam a interação dos sujeitos nos espaços coletivos. Como diria G. Campos (2000), uma capacidade de co-produzir valores de uso e necessidades; dominar e criar consensos; projetar e introjetar valores e necessidades pessoais; interferir no desejo e nas pulsões sem desconsiderar os constrangimentos da realidade e os interesses alheios.

É uma categoria política na sua essência, de caráter eminentemente dialético, que se situa no lugar imaginário do pensamento e tem a intenção de pensar a realidade, mantendo o status quo ou transformando-a. Situa-se também no lugar da práxis, entendida a prática que transforma e é transformada pela ação do poder, um chamamento filosófico que, no bojo de sua complexidade epistemológica, revela o recurso terapêutico do poder sobre os sujeitos e sobre os coletivos no momento do planejamento. Apoiamos-nos na concepção de G. Campos (2000), que estabelece a função terapêutica do poder como superior à ideia de dispositivo.

Partindo desses princípios, podemos intuir que o poder tem como pano de fundo a análise das práticas, das estruturas e das formações, que constituem os arcabouços simbólico, filosófico, ideológico, político e pragmático da sociedade.

Desenvolvemos, portanto, com base nos acúmulos teóricos que conseguimos na leitura dos autores supracitados, uma matriz analítica para discutir a categoria poder, cujas dimensões foram identificadas como a simbólica, filosófica e ideológica; a político-econômica; e a da práxis (Quadro 02). Todas essas dimensões trabalham as questões relacionadas ao poder nos planos de análise das práticas, das estruturas e das formações, relacionando-se entre si na conformação do poder.

O plano de análise das práticas tem como unidade principal o conjunto das atividades estruturadas e articuladas entre si, de modo a garantir a produção de um efeito dominante. O plano das estruturas discute os aparelhos de reprodução social, ideológica e filosófica, que, articulados, constituem o terceiro plano analítico - o das formações. 0 plano das estruturas articula diferentes níveis de práticas a um determinado efeito dominante. $\mathrm{O}$ plano das formações articula aparelhos de reprodução de diversos 
níveis, subordinando-o a um único aparelho dominador; estabelece os objetos teóricos que dão subsídio ao pensamento hegemônico, materializado em totalidades históricas e formas sociais. (ALBUQUERQUE, 1986)

\section{QUADRO 02: Dimensões analíticas do poder}

\begin{tabular}{|c|c|c|}
\hline \multicolumn{3}{|c|}{ P O D E R } \\
\hline $\begin{array}{l}\text { DIMENSÃO SIMBÓLICA, } \\
\text { FILOSÓFICA E } \\
\text { IDEOLÓGICA }\end{array}$ & $\begin{array}{c}\text { DIMENSÃO } \\
\text { POLÍTICO-ECONÔMICA }\end{array}$ & DIMENSÃO DA PRÁXIS \\
\hline $\begin{array}{l}\text { PODER SIMBÓLICO } \\
\text { PODER FILOSÓFICO } \\
\text { PODER IDEOLÓGICO }\end{array}$ & $\begin{array}{l}\text { PODER POLÍTICO } \\
\text { PODER TECNOCRÁTICO } \\
\text { PODER ECONÔMICO }\end{array}$ & $\begin{array}{l}\text { PODER TÉCNICO } \\
\text { PODER REACIONÁRIO }\end{array}$ \\
\hline $\begin{array}{l}\text { SIMBOLISMOS; } \\
\text { SIGNOS; } \\
\text { SENTIDOS; } \\
\text { SIGNIFICAÇÕES; } \\
\text { CULTURA; } \\
\text { FILOSOFIAS; } \\
\text { IDEOLOGIAS; } \\
\text { REALIDADE SIMBÓLICA; } \\
\text { REPRESENTAÇÕES } \\
\text { SUBJETIVAS; } \\
\text { MANIPULAÇÃO. }\end{array}$ & $\begin{array}{c}\text { JOGO DE INTERESSES; } \\
\text { DISPUTA; } \\
\text { RELAÇÃO DOMINAÇÃO / SUBORDINAÇÃO; } \\
\text { HEGEMONIA; } \\
\text { ORGANIZAÇÃO PARA } \\
\text { A PRODUÇÃO; } \\
\text { ALIENAÇÃO; } \\
\text { SILENCIAMENTO; } \\
\text { VELAMENTO DO SUJEITO; } \\
\text { REALIDADE OBJETIVA; } \\
\text { REPRESENTAÇÕES } \\
\text { OBJETIVAS; } \\
\text { LEGITIMAÇÃO DA FORÇA. }\end{array}$ & $\begin{array}{l}\text { DETERMINAÇÕES SOCIAIS; } \\
\text { LUTA CONTRA-HEGEMÔNICA; } \\
\text { AUTONOMIA; } \\
\text { CO-PRODUÇÃO DE } \\
\text { NECESIDADES; } \\
\text { (DES) ALIENAÇÃO; } \\
\text { LIBERTAÇÃO; } \\
\text { DESVELAMENTO DO SUJEITO; } \\
\text { REALIDADE SUBJETIVA; } \\
\text { INTERVENÇ̃̃O. }\end{array}$ \\
\hline $\begin{array}{l}\text { PRÁTICAS, ESTRUTURAS } \\
\text { E FORMAÇÕES } \\
\text { CONSERVADORAS. }\end{array}$ & $\begin{array}{l}\text { PRÁTICAS, ESTRUTURAS E FORMAÇÕES } \\
\text { CONSERVADORAS. }\end{array}$ & $\begin{array}{l}\text { PRÁTICAS TRANSFORMADORAS, } \\
\text { ESTRUTURAS REVOLUCIONÁRIAS } \\
\text { E FORMAÇÕES LIBERTADORAS. }\end{array}$ \\
\hline & TOTALIDADE CONCRETA & \\
\hline $\begin{array}{l}\text { IDEAL SIMBÓLICO, } \\
\text { FILOSÓFICO E } \\
\text { IDEOLOOGICO }\end{array}$ & $\begin{array}{l}\text { IDEAL POLÍTICO E } \\
\text { ECONÔMICO }\end{array}$ & $\begin{array}{c}\text { IDEAL } \\
\text { LIBERTÁRIO }\end{array}$ \\
\hline $\begin{array}{l}\text { TOTALIDADE } \\
\text { IDEOLÓGICA E OBJETIVA }\end{array}$ & $\begin{array}{c}\text { TOTALIDADE } \\
\text { POLÍTICA, ECONÔMICA E CONTEXTUAL }\end{array}$ & $\begin{array}{l}\text { TOTALIDADE } \\
\text { HISTÓRICA E SUBJETIVA }\end{array}$ \\
\hline \multicolumn{2}{|c|}{ MANUTENÇÃO DO STATUS QUO } & $\begin{array}{l}\text { MUDANÇA OU TRANSFORMAÇÃO } \\
\text { DA REALIDADE }\end{array}$ \\
\hline
\end{tabular}

Este quadro foi construído tomando como bases orientadoras as produções de Albuquerque (1986); Matus (1993); Giovanella e Fleury (1991); Testa (1995, 1997, 2004); G. Campos (2000); Foucault (2003); Bobbio (2000); e Freire $(1987,1996)$.

3 Entendemos que o poder reacionário é o poder das massas. Alicerçamo-nos no entendimento de que a práxis, na busca da transformação da realidade, busca recurso no "saber" para lutar pelo poder - é o movimento de aproximação entre o senso comum e o saber científico. Portanto, assumimos um híbrido conceitual de Testa (1995) e Foucault (2003) para identificar esta forma de poder como comple- 
A dimensão simbólica, filosófica e ideológica responderia pelo que Albuquerque (1986) identifica como nível ou instância ideológica de análise, através da qual se estudam as representações do processo de produção e repressão dos sujeitos e dos coletivos. Trata-se de uma instância que, utilizando-se de metáforas e metonímias, caracteriza o aparelho ideológico existente numa dada realidade e determina a forma como as relações de poder são ideologicamente constituídas. Neste sentido, aparecem no cenário o poder legitimado (divino), o poder representativo (formal) e o poder relacional (real).

O poder legitimado é resultante de uma relação intersubjetiva de subserviência, na qual a capacidade pessoal de cada indivíduo se sobrepõe à vontade coletiva, sustentado no paradigma da divindade. 0 poder representativo resulta da relação intersubjetiva de transferência, na qual os indivíduos estabelecem entre si acordos transitórios de transferência da capacidade decisória para sujeitos que possuem a faculdade inter e intragrupal de exercer o poder. E o poder relacional resultante da relação intersubjetiva de solidariedade, na qual os sujeitos, através de interações comunicativas e pactos, estabelecem a capacidade de exercer o poder como uma atitude coletiva, permeada pelos princípios da participação e do sentido comunitário. (ROSO; BUENO; GUARESCHI, 2000)

O que é ideologicamente constituído reflete nas relações de poder que se estabelecem entre os sujeitos em ação e, de certa forma, interfere no processo de construção da realidade objetiva. A dimensão ideológica do poder é o alicerce das estruturas políticas da sociedade e desencadeia uma série de reações sociais e lutas na busca pelo poder. Um paradoxo, pois as ideologias existentes na sociedade lutam pelo alcance da hegemonia, mesmo que se intitulem como contra-hegemônicas.

Giovanella (1996) trata da questão da ideologia, como já dissemos, partindo da compreensão que não se faz política sem lutas ideológicas. E que o exercício do poder é uma prática construída por sujeitos sociais em ação, organizados na sua relação com os outros sujeitos, com a sociedade e

mentar nas lutas contra-hegemônicas para a (des) alienação e para a libertação dos sujeitos. O poder reacionário, quando organizado, transforma a realidade através da sua força histórica revolucionária, subordinando, inclusive, as outras formas de poder no momento da sua ação. 
com o Estado. Seria o que denominamos estruturas políticas da sociedade pautadas nas relações intersubjetivas, nas interações comunicativas e nos pactos.

Sá (2001) corrobora com a afirmação acima, identificando as relações de poder como relações de mal-estar, mediadas por processos dinâmicos subjetivos e intersubjetivos de tensão. Nas lutas veladas de poder nas organizações de saúde, os sujeitos assumem, às vezes, posições excludentes e segregatórias, expressando uma agressividade que, no contexto, contribui para o incremento da violência institucional, o que desencadeia uma série de malefícios coletivos, que a conduzem ao sofrimento ético, à deterioração e à banalização.

Nesse sentido, a dimensão filosófico-ideológica estuda, nas relações de poder, os componentes simbólicos, as significações, as ideologias e as representações dos sujeitos, entendendo que essas relações são construídas a partir de práticas, estruturas e formações, que, na sua totalidade concreta, podem se apresentar como conservadoras ou como transformadoras, dependendo da ideologia dos diferentes sujeitos que compõem os grupos sociais em situação de hegemonia ou contra-hegemonia.

A segunda dimensão de análise do poder é a político-econômica, entendida como aquela que possui maior complexidade, haja vista comportar em si diversas contradições. É a dimensão "escondida" nas relações de poder que se estabelecem no cotidiano das estruturas, corroborando com G. Campos (2000), que explicita ser na dimensão política onde se disputa expressivamente o poder.

Segundo Bobbio $(2003,2005)$, esta dimensão se alicerça no poder político: tipo de poder que se sustenta através da força e da coerção, ou seja, parte do princípio que existe um grupo dominante cujos interesses se sobrepõem aos interesses da sociedade, numa relação de dominação e subordinação; e no poder econômico, que se vale da posse de bens necessários em situação de escassez para induzir os que não os possuem a um comportamento de submissão.

Testa $(1995,1997,2994)$ coaduna com as percepções de Bobbio $(2003,2005)$ e de G. Campos (2000), acrescentando que o poder político é o resultado de uma combinação entre o saber e a prática, numa lógica racionalista, porém dialética, cujos elementos apontam para a utilização 
da força como instrumento de manutenção do poder. Uma força capaz de desencadear uma mobilização sobre os sujeitos para atuar sobre a realidade segundo os interesses das classes dominantes.

A mobilização das forças para a manutenção do poder se materializa com a organização para a produção, para o consenso e para a coerção. (BOBBIO, 2005)

A organização para a produção sistematiza os processos de trabalho para a manutenção do status quo, causando o silenciamento revolucionário; a organização para o consenso sistematiza as concepções teórico-filosóficas e também causa o silenciamento ideológico; e, por fim, a organização para a coerção, assentada no aparato jurídico institucional, promove o silenciamento político, verificado pela apatia e pela alienação dos sujeitos submetidos à concepção hegemônica.

A terceira e última dimensão de análise do poder é a dimensão da práxis, entendida como a dimensão da prática para a transformação da sociedade, pois trabalha com a produção e com a reprodução social. É sobre a práxis que se assenta a discussão da autonomia, da (des) alienação e da libertação dos sujeitos.

Sá (2001) discute que as forças desagregadoras do tecido social, tais como a intensificação do individualismo; o culto ao corpo; o desenvolvimento do narcisismo de morte; e uma vontade de eficácia a qualquer preço, têm levado os sujeitos das organizações de saúde a supervalorizar a dimensão econômica e a obsessão pela modernização na dinâmica dos seus processos de gestão. Isso tem ocasionado, segundo a autora, uma brutal desvalorização da vida individual e coletiva, causando abandono das práticas de enfrentamento das questões que afligem a sociedade.

G. Campos (2000) afirma que, com os recursos da práxis, os sujeitos em ação podem desenvolver suas capacidades de interferir e negociar com a realidade externa, trabalhando seus desejos e interesses, de modo a co-produzir necessidades sociais e influir nos modos de atenção a elas.

Partindo deste pressuposto, a práxis do poder enquanto categoria é subjetiva e envolve temas éticos, estéticos, políticos, técnicos e reacionários, configurando-se também como um plano de complexidades para o enfrentamento das forças desagregadoras da sociedade. Assenta-se sob a 
égide da (des)alienação, uma capacidade que resulta da compreensão concreta do sonho possível e do ideal de liberdade, entendidos, na sua essência, como consciência das necessidades, da autonomia e do saber.

Albuquerque (1986) discute que é no plano das práticas que se assenta a instância ou nível econômico da análise, compreendido pela dicotomia entre o trabalho e seu produto concreto. No entanto, G. Campos (2000) categoriza esta instância analítica relacionando-a com a questão dos valores de uso dos bens e serviços produzidos no sistema econômico, como parte da totalidade concreta que se relaciona com a dimensão política.

A dimensão da práxis suscita, portanto, a discussão acerca das capacidades no campo do poder. Como já explicitado, G. Campos (2000) identifica a práxis como uma capacidade de interferir sobre uma realidade, transformando-a ou mantendo a ordem instituída. Neste sentido, adotamos esta explicitação, esclarecendo que a práxis do poder é uma capacidade para intervir e transformar a realidade, um desafio conceitual e prático que se estabelece no campo da Saúde Coletiva, principalmente no período relacionado ao recorte temporal do estudo - o período de implementação do SUS.

O objeto do planejamento, permeado pela discussão do poder enquanto capacidade, assume as dimensões do simbolismo filosófico-ideológico, da política e da práxis para responder a ideais de totalidade (objetos reais) que visam: ou a manutenção do status quo, ou a transformação da realidade.

O planejamento em saúde para a manutenção do status quo seria uma re-significação do planejamento normativo, concentrado no consenso da base populacional para decidir problemas econômicos de apropriação, destinação de recursos e distribuição de produtos aos casos em que o poder é compartilhado como reflexo de conflitos sociais, cujos problemas são organizativos e sinalizados em diversos níveis; e o planejamento em saúde para a transformação da realidade, uma re-significação do enfoque estratégico, pautado numa visão dialética de sociedade, situando o sujeito/ator social no campo situacional, relacionando-o a elementos políticos, econômicos e sociais que conformam a sua totalidade complexa. 


\section{O PLANEJAMENTO EM SAÚDE PARA A MANUTENÇÃO DO STATUS QUO: UMA PRÁTICA HEGEMÔNICA E CONSERVADORA}

[...] a planificação normativa é um procedimento que tende a fixar normas de conteúdo racional e consistentes entre si que se referem a um momento futuro, as metas quantificadas e ligadas temporal e espacialmente não são confrontadas com nenhuma opinião contrária, o plano, em seu conjunto, não tem oponentes e o planificador é um técnico a serviço do político, que trabalha em uma oficina que forma parte do governo, para a qual o objeto da planificação é o sistema econômico-social [...]. (TESTA, 2004)

Com esta afirmação de Testa (2004), iniciamos o caminhar para discutir o planejamento em saúde como uma prática hegemônica e conservadora. Tomaremos como elementos de análise as dimensões explicitadas no Quadro 02, cuja totalidade parcial aponta para os ideais que dão suporte às diferentes formas de poder que compõem o campo das totalidades concretas para a manutenção do status quo.

No nosso entendimento, não é possível se discutir práticas hegemônicas sem discutir os conceitos que norteiam essas práticas. Por isso, iniciaremos apresentando breves considerações sobre a questão da hegemonia enquanto conceito e sua relação com as práticas adotadas por aqueles que, utilizando-se da concepção de hegemonia, impõem sua vontade àqueles que lhes são subordinados.

Campione (2003), inspirado em Gramsci, discute o conceito de hegemonia, explicitando que os componentes da hegemonia e da coerção co-existem no tempo e no espaço como componentes da supremacia de uma classe que passa a ser dirigente sem deixar de ser dominante exerce poder sobre um espaço social mais amplo que os dos aparatos estatais formalmente reconhecidos. A direção intelectual e moral da sociedade parte de grupos sociais com um papel determinado, e a vida econômica para hegemonizar outros grupos com papéis igualmente determinados. 0 jogo de interesses estabelecidos no campo econômico-corporativo e no plano ético-político produz uma hegemonia couraçada de coerção, porém alicerçada, paradoxalmente, nos ideais da democracia. 
Poderíamos dizer, então, que hegemonia é um estado político de dominação ideológico-filosófica e simbólica que se assenta na luta velada das classes sociais na busca do poder, sem perder de vista a questão da democracia. Portanto, no campo do planejamento, o pano de fundo ideológico, ainda que economicamente determinado, é o estabelecimento de um Estado que dê conta dos direitos sociais sem perder de vista as necessidades individuais e coletivas.

Neste sentido, Fleury (1996) identifica o Estado de Bem-estar Social, a alternativa social; o Estado Neoliberal, uma adaptação do Estado Liberal de Direito, denominado como a alternativa neoliberal; e o Estado Democrático de Direito, denominado democrático, ainda que voltado para interesses individuais. Alternativas que conjugam interesses individuais e coletivos na direção da manutenção de um ideário econômico.

Mizoczky (2002), discutindo as concepções de direitos sociais e sua relação com o Estado, apresenta suas impressões acerca dos focos das políticas públicas relativas aos direitos sociais nos Estados do tipo social, neoliberal e democrático. A alternativa social, segundo a autora, agrega ao ideário liberal a concepção de bem-estar social, tendo como instrumento de ação concreta a lei, que, aplicada, visa a facilitação do acesso dos grupos populacionais aos serviços essenciais. A alternativa neoliberal, por sua vez, possui instrumentos jurídicos que visam assegurar o livre desenvolvimento das pretensões individuais, limitando o papel do poder público a ações regulamentadoras e regulatórias. A alternativa democrática agrega ao ideário liberal a questão da igualdade de direitos e da solidariedade, e tem uma aproximação filosófica com os ideais libertários no que se refere à busca de transformações sociais, ainda que economicamente determinadas.

A institucionalização dos direitos sociais é o pano de fundo ideológico para a consolidação do planejamento normativo re-significado - um instrumento de organização para a produção e legitimação da força. Nesse sentido, o modelo econômico estabelece como desafio principal a criação de uma dada ambiência para o consumo. Fato que impulsiona, no campo da saúde, o desenvolvimento de estratégias de enfrentamento da pobreza, como políticas de compensação e de fortalecimento da capacidade aquisitiva da população. Essas políticas compensatórias, por sua vez, impulsio- 
nam o sistema, que se obriga a desenvolver programas verticalizados para responder a demandas específicas, voltadas ao cumprimento de metas economicamente constituídas.

G. Campos (1992) aborda as reformas do modelo assistencial do SUS como resultado de uma discussão iniciada por organismos internacionais de saúde cujas concepções fluidificam a reprodução e a permanência da lógica neoliberal. Para ele, a descentralização do poder técnico e administrativo, para a constituição de sistemas locais de saúde, não altera o modo de produção e a lógica diretora do modelo. Ao contrário, configura-se como uma nova roupagem ao estado de espírito instituído, uma reinvenção.

Naquele momento o autor já discutia a questão da política neoliberal e a sua relação com a saúde na constituição do sistema brasileiro. Segundo ele, no Brasil há um modo hegemônico de se produzir serviços médico-sanitários - o neoliberal. Esse modelo se institui entremeado pela concepção hegemônica da medicina liberal, jurídico-socialmente aceita e absorvida pela sociedade, cujos fundamentos são: a livre escolha do médico pelo paciente; a liberdade de prescrição por parte do médico; o acordo direto entre médico e paciente em matéria de honorários; e o pagamento direto dos honorários pelo paciente ao médico.

A lógica política e ideológica dos defensores do projeto neoliberal no Brasil para assegurar a hegemonia se assenta, segundo G. Campos (1992), em dois movimentos importantes. O primeiro, relacionado a interesses econômicos classistas, que se institui como defensor da medicina privatista, que tem em si o corpo dos médicos liberais, das cooperativas médicas e das empresas de planos e seguros de saúde. E o segundo, relacionado aos grupos de interesse vinculados ao empresariado da medicina de grupo, aos confederados de hospitais e instituições filantrópico-beneficentes e aos conselhos de medicina, nos seus diferentes níveis.

A maior parte da produção dos serviços de saúde, incluindo os serviços médicos, está voltada para o atendimento individual e curativo. As portas de entrada para o sistema são múltiplas e estão condicionadas à lógica do mercado, tanto no sentido horizontal quanto no sentido vertical, isto é, o "paciente" tem acesso ao sistema de saúde ou através de programas verticalizados instituídos pelo governo para responder a metas de estabi- 
lização econômico-sociais; ou pela aquisição individual direta ou indireta de acesso financiado, através dos sistemas de desembolso. (CAMPOS, G., 1992; MENDES, 1999)

No arcabouço de sua discussão, G. Campos aproxima as reformas do modelo assistencial do SUS a um conjunto de reformas modernizadoras da estrutura do sistema de saúde, visando aumentar sua produtividade e sua racionalidade organizacional, utilizando-se, para isso, do arsenal da tecno-burocracia e do planejamento normativo, ainda que a concepção política abstrata seja alicerçada no ideário da Reforma Sanitária.

A organização do processo de trabalho para a produção, nesses modelos, implica no planejamento de atividades com objetivos programáticos previamente estabelecidos, refletindo um planejamento autoritário, caracterizado pela centralização normativa e pela descentralização executiva. Cada equipe de trabalho, minimamente organizada, estaria submetida ao cumprimento de um conjunto de metas e objetivos definidos, a partir de um sistema de negociações orientadas pelo plano estratégico global e pelas propostas oriundas do pessoal da base do sistema. (CAMPOS, G., 1992)

Trata-se, portanto, da organização do processo de trabalho para a produção. Uma reprodução alienante de práticas conservadoras para a manutenção da ordem político-econômica e estabelecimentos de focos assistenciais para responder a demandas específicas, muitas vezes determinadas no tocante ao tempo e ao espaço de sua ação. Um movimento de fortalecimento da hegemonia em detrimento da contra-hegemonia e da anti-hegemonia. (ALBUQUERQUE, 1986)

No campo da Saúde Coletiva, o planejamento para a manutenção do status quo também se configura como um modelo hegemônico e conservador de direcionamento político e tecnocrático da ação. $O$ privilégio dado à atuação racionalizadora com vistas ao alcance da eficiência e da efetividade, demonstra que, mesmo no campo de conhecimento de uma área político-social, encontra-se enraizada a concepção econômica e a totalidade alienante, que pode se revelar em aproximações teórico-conceituais a elementos de manutenção da ordem econômica, inclusive aplicando esquemas de impacto tecnológico, de acordo com os preceitos neoliberais, ao cotidiano dos serviços de saúde. 
Podemos citar como exemplos a utilização prática do método Desdobramento Função Qualidade (DFQ), cuja finalidade é a racionalização dos custos no processo de trabalho, ainda que velada pela propaganda da satisfação das necessidades dos usuários, traduzida na expressão mercadológica "foco no cliente"; e a prestação de serviços de saúde com base no Gerenciamento do Caso (GC), baseado na atenção gerenciada norte-americana. (GONZALES, 2003; MATSUDA; ÉVORA; BOAN, 2000)

Cecílio (1997), ao realizar o estudo dos modelos tecno-assistenciais em saúde, identifica que as contradições do modelo da pirâmide se revelam: pelos limites econômicos impostos pela conjuntura para viabilizar o fluxo ascendente/descendente dos usuários no sistema, dada a insuficiência dos recursos aplicados em saúde; pela hegemonização do setor privado em detrimento do setor público, que é silenciado pela disputa e pelo jogo de interesses dos grupos econômicos; pela pressão tecnológica, que torna complexo o processo de trabalho e expõe a baixa resolubilidade dos níveis primários. Isto pode causar sobrecargas assistenciais que contribuem para o sucateamento e para a exclusão de usuários e o fortalecimento da iniciativa privada. Observamos que, pela configuração polimórfica e conflituosa da "porta de entrada" do sistema, esta estabelece diferentes níveis de entrada ao usuário, fato que aproxima essa perspectiva do ideário liberal da livre escolha, ainda que regulada.

Teixeira (2003) estabelece um contraponto na discussão dos modelos tecno-assistenciais, demonstrando teoricamente que as propostas de mudança político-gerenciais, com a introdução de novas tecnologias de gestão, favorecem a construção de perspectivas de mudança nas práticas de saúde, o que, por conseguinte, vai de encontro à hegemonização paradigmática da alienação. Os loci de operacionalização dessas práticas contribuem para o estabelecimento de diferenciais nas finalidades, no objeto e no sujeito do processo de trabalho, tanto no sentido macro-organizacional, com a organização de macromodelos, quanto no sentido micropolítico, com a reorientação da práxis. 


\title{
O PLANEJAMENTO EM SAÚDE PARA A MUDANÇA OU TRANSFORMAÇÃO DA REALIDADE: A CONTRA- HEGEMONIA CONSTRUÍDA NO CAMPO DA SAÚDE COLETIVA
}

\begin{abstract}
O procedimento estratégico difere do normativo pelo fato de não tentar estabelecer normas senão desencadear processos permanentes de discussão e de análise dos problemas sociais, que leva a propor metas necessariamente conflitivas, visto que se referem a interesses de grupos em disputa, cada um com planos próprios, de modo que o planificador é parte de alguma força social, para a qual o objetivo da planificação se inscreve no marco da luta pelo poder [...]. (TESTA, 2004)
\end{abstract}

O ponto de partida para discutir o planejamento como uma prática contra-hegemônica é apreender, a partir da afirmação acima, o sentido e o significado do planejamento em saúde, complementando-o com a concepção de Carlos Matus, o pai do Planejamento Estratégico Situacional.

Ao formular uma teoria geral de estratégia política, Matus (1993) identifica o processo de produção social como o elemento fundamental de um jogo conflitivo e conflitante de interesses estabelecidos num cenário político. Para ele, toda produção tem, indistintamente, uma dimensão econômica, uma dimensão política, uma ideológico-cultural, uma cognitiva, uma jurídico-social e uma ecológico-espacial. São essas dimensões, associadas aos recursos do poder aplicados pelos sujeitos/atores sociais e pelas relações essenciais do sistema produtivo, que têm como consequência acumulações, alicerçadas nas estruturas da sociedade, determinadas pela realidade - dinâmica e contraditória.

Misoczky (2002), ao analisar a questão do poder em Matus, identifica que o foco dado pelo autor está nas estruturas produtivas e produzidas, entendidas como capacidades acumuladas; e na questão sujeito/ator social, cuja definição está relacionada com a capacidade de ação e o peso coletivo desse "ator" no jogo, isto é, em situação.

As estruturas definidas por Matus (1993) são: as genoestruturas, entendidas como as regras básicas do jogo; as fenoestruturas, vistas como as acumulações humanas, ou seja, a capacidade de fatos, bens, serviços econômicos e valores. No tocante a essas definições, Misoczky (2002) afirma 
que as fenoestruturas (acumulações) e a produção (fluxos) existem ou se realizam constantemente no espaço de produção do jogo social, enquanto as genoestruturas são as regras que determinam esse jogo.

No cenário do jogo social se estabelecem as relações de poder. E Matus contextualiza de forma crítica e reflexiva ao desenvolver a proposta do Planejamento Estratégico Situacional. Tanto que afirma ser o planejamento um processo social, no qual todos os atores em situação de governo possuem uma capacidade própria - conduzir um processo de mudança. Assim, planejar, na concepção de Matus (1993), é uma capacidade de descobrir passos para transformar a realidade, entendida como cenário de disputas, de guerra, onde os sujeitos/atores sociais devem desenvolver estratégias para predizer e prever as incertezas, reagir prontamente ante as surpresas e aprender com seus próprios erros nas trincheiras do cotidiano.

A mudança discutida por Matus se aproxima do que identificamos como transformação, apesar de existirem algumas diferenças conceituais entre elas, que as distanciam e revelam as contradições estabelecidas na luta contra a hegemonia.

O Dicionário Houaiss da língua portuguesa (2001) define "mudança" como "[...] o ato ou efeito de mudar, ou mudar-se; transformação decorrente de certos fenômenos; alteração de processos, expectativas". Por sua vez, define "transformação" como "[...] o ato ou efeito de transformar-se; converter-se; alterar-se; modificar-se; transfigurar-se”. (HOUAISS, 2001)

A mudança, portanto, é um ato externo ao sujeito e a transformação é um ato intrínseco a ele. Se quisermos um planejamento para a transformação, deveremos ser atuantes para não corrermos o risco de estarmos excluídos do processo, ou seja, é necessário estarmos conscientes enquanto sujeitos da história sem perder de vista as dimensões da singularidade e da subjetividade.

O planejamento em saúde para a transformação da realidade tem como pano de fundo um ideal libertário, pautado em práticas transformadoras que se estabelecem em estruturas revolucionárias para produzir sujeitos (des) alienados e autônomos, cônscios de suas responsabilidades históricas e do seu papel na luta contra-hegemônica, na co-produção de necessidades e na transformação da realidade objetiva, subjetivamente construída. 
O cenário de lutas do planejamento transformador é político, ideológico e prático. Um cenário polimórfico, multidimensional, histórico. É o cenário da práxis, compreendida como uma prática social.

O jogo estabelecido nesse cenário é o jogo social, onde os sujeitos, imbuídos do poder transformador de suas práticas, utilizam-se de estruturas revolucionárias para propagar seus ideais de libertação.

O planejamento transformador, em que pese a sua aproximação com a utopia, é um horizonte possível, pois tem como principal tecnologia o sujeito e sua relação com a sociedade e com a natureza. É um planejamento livre das amarras do poder econômico; do jogo de interesses escusos das classes dominantes; das disputas veladas de poder. Possui uma lógica produtiva diferenciada, pautada na co-produção de necessidades e na produção da autonomia - no desvelamento dos sujeitos.

O desafio é alcançar essa utopia!

Desde Matus, com o PES, até os métodos de planejamento pautados no enfoque participativo, todos propuseram um arsenal de instrumentos para intervir sobre a realidade social e transformá-la. Partiram sempre da crítica ao status quo como motivação para desenvolver suas estratégias de enfrentamento às adversidades socialmente determinadas, ou seja, desenvolver capacidades de intervir sobre a realidade, transformando-a.

O foco das discussões que alicerçam o caráter transformador do planejamento é a questão das capacidades coletivas - um poder à parte na discussão do planejamento, estabelecido, segundo Testa (1995), na tríplice relação entre os sujeitos, objetos e outros sujeitos.

As capacidades coletivas promovem verdadeiras revoluções quando utilizadas de modo coerente e ideologicamente correto, se é que podemos dizer assim. Ter capacidade é ter autonomia, é ser (des) alienado, livre. É ser capaz de fazer, intervir, avaliar, agir, mediar, transformar. O sujeito capaz é o sujeito transformador, que utiliza o seu poder para revolucionar a história, para estabelecer diferenciais positivos no cenário da vida.

Gramsci (1991) afirma: "cada um transforma-se a si mesmo, se modifica, na medida em que transforma e modifica todo conjunto de relações do qual ele é o ponto central". Com isso, testificamos que verdadeiramente o planejamento transformador somente existirá se o seu foco for o sujeito 
transformado, o que aproxima essa discussão das concepções apresentadas por Foucault (2003), quando discute as questões do poder com enfoque sobre a subjetividade.

Giovanella (1990), ao discutir a produção teórica de Mário Testa, identifica que este autor trabalhou a perspectiva de um planejamento em saúde para a mudança e transformação social, para a intervenção na construção da história. O entendimento de Testa acerca de saúde como "um jeito de andar a vida", que os problemas de saúde são problemas sociais complexos e que não é possível mudar a realidade social com propostas setoriais, demonstra que a visão desse pesquisador, segundo a autora, aponta para uma totalidade social indivisível, que só pode ser transformada com o enfrentamento da questão do poder, entendida como um poder-capacidade ${ }^{4}$ ou como um poder-relação $0^{5}$, e com o enfrentamento da ideologia, compreendida como a relação entre o saber a prática dos sujeitos expressos em seus arcabouços simbólicos e filosóficos.

Artmann, Azevedo e Sá (1997), ao dissertarem sobre as possibilidades e os limites do enfoque estratégico de planejamento no nível local de saúde, discutem a importância dos sujeitos no momento da determinação dos pactos e negociações coletivas e da comunicação como subsídio para o estabelecimento de prioridades. Os sujeitos, segundo as autoras, gozam de certo nível de autonomia que, aliado à conjuntura local, determinam a viabilidade de um projeto, demonstrando que eles podem individualmente apresentar a capacidade de influenciar na condução dos processos de mudança e de transformação.

Pedrosa (1997), tratando a intervenção pedagógica enquanto modelo de transformação coletiva, assenta-se sobre a concepção de sujeito enquanto aquele que busca constantemente autonomia; um desafiador; um desbravador capaz de perceber seu papel diante dos desafios em cada momento. Diz também que esse sujeito se constrói num conjunto de relações dialéticas e dicotômicas, instituídas nos espaços coletivos, isto é, no

4 Poder-capacidade, segundo Giovanella (1990), é aquele que se estabelece no campo das individualidades, se considerarmos os indivíduos, os grupos e as classes sociais isoladamente.

5 Poder-relação, segundo Giovanella (1990), é aquele que se estabelece no campo das relações entre os sujeitos, os objetos e os outros sujeitos, uma relação tríplice, na mediação dos interesses individuais, de grupo ou das classes sociais. 
desvelamento das relações de poder que se revelam nos cenários de sua atuação.

Assis, Pereira e Mishima (1997) coadunam com as ideias de Pedrosa no tocante à instituição da autonomia dos sujeitos nos espaços coletivos como dialeticamente construídas, porém afirmam que para concretizá-la é necessário que se desenvolva entre eles - sujeitos, intérpretes ${ }^{6}$ e participantes $^{7}$ - uma interação participativa constante, que pode ser consolidada com ações de planejamento orientadas pela diretriz da participação da comunidade.

Adotando a mesma perspectiva do planejamento participativo, Piovesan e colaboradores (2005) e Bursztyn e Ribeiro (2005), estabelecem processos de avaliação política e estrutural com o enfoque na participação dos sujeitos para levantamento diagnóstico, contextualização e intervenção nas realidades concretas dos serviços de saúde. Utilizam-se das prerrogativas do ideal libertário da pedagogia da práxis para desenvolver dispositivos participativos de planejamento com vistas a atuar sobre suas realidades, transformando-as no limite do possível.

R. Campos (2000), ao enfatizar a necessidade de se resgatar a racionalidade instrumental, propondo a construção de uma nova instrumentalidade, explicita que, em que pesem as diferentes vertentes tecnológicas que se desenvolveram no campo do planejamento em saúde, o que de fato não deve ser jamais esquecido é o sujeito - quem planeja.

Paim (2003), por sua vez, apresentando a epidemiologia como instrumento de formação de sujeitos sociais, discute a possibilidade de se instituírem tecnologias de poder capazes de impulsionar os sistemas de saúde para uma prática sanitária pautada na generosidade, solidariedade e ética, num processo de construção contra-hegemônica, cujos participantes, independentes e interdependentes, contribuiriam para a redução do sofrimento humano, das iniquidades sociais detectadas e para o fortalecimento dos movimentos em defesa da vida.

6 Intérpretes dizem respeito aos sujeitos imbuídos do status privilegiado de dirigentes no espaço institucional.

7 Participantes são todos aqueles que não são intérpretes no processo de comunicação participativa. 
Uma coisa é fato: o planejamento transformador é um híbrido polimórfico de capacidades transformadoras, cujo arsenal metodológico é pautado nas tecnologias leves, valorizando a subjetividade, ainda que não se apartando de certa racionalidade instrumental. Seria um planejamento sem normas, porém com normas; um dispositivo com função terapêutica sobre os sujeitos e sobre a sociedade, capaz de tratar suas mazelas conduzindo-os à sua cura definitiva - uma utopia possível, brindada com doses de realidade.

\section{REFERÊNCIAS}

ALBUQUERQUE, J. A. G. Instituição e poder: a análise concreta das relações de poder nas instituições. 2. ed. Rio de Janeiro: Edições Graal, 1986.

ARTMANN, E.; AZEVEDO, C. S.; SÁ, M. C. Possibilidades de aplicação do enfoque estratégico do planejamento no nível local de saúde. Análise de duas experiências. Cad. de Saúde Públ., Rio de Janeiro, v.13, n. 4, p. 723-740, 1997.

ASSIS, M. M. A.; PEREIRA, M. J. B.; MISHIMA, S. M. Planejamento em Saúde: uma possibilidade de ação comunicativa. Rev. Latino-americana de Enferm., Ribeirão Preto-SP, v. 5, n. 4, p. 55-60,1997.

BOBBIO, N. Estado, Governo e Sociedade: para uma teoria geral da política. 12. ed. Tradução Marco Aurélio Nogueira. Rio de Janeiro: Paz e Terra, 2005.

. Noberto Bobbio: o filósofo e a política (antologia). Organização e apresentação José Fernández Santillán; tradução César Benjamin e Vera Ribeiro. Rio de Janeiro: Contraponto, 2003.

. Teoria geral da política: a filosofia e as lições dos clássicos. Organizado por Michelangelo Bovero; tradução Daniela Baccaria Versiani. Rio de Janeiro: Elsevier, 2000 .

BURSZTIN, I.; RIBEIRO, J. M. Avaliação participativa em programas de saúde: um modelo para o Programa de Saúde do Adolescente. Cad. de Saúde Públ., Rio de Janeiro, v. 21, n. 2, p. 404-416, 2005.

CAMPIONE, Daniel. Hegemonia e contra-hegemonia na América Latina. In: COUTINHO, Carlos Nelson; TEIXEIRA, Andréa de Paula (Org.). Ler Gramsci e entender a realidade. Rio de Janeiro: Civilização Brasileira, 2003. p. 51-63.

CAMPOS, G. W. S. Um método para análise e co-gestão de coletivos. São Paulo: Hucitec, 2000.

. Reforma da reforma: repensando a saúde. São Paulo: Hucitec, 1992. 
CAMPOS, R. T. Planejamento e razão instrumental: uma análise da produção teórica sobre, o planejamento estratégico em saúde, nos anos noventa, no Brasil. Cad. de Saúde Públ., Rio de Janeiro, v.16, n.3, p.723-731, 2000.

CECILIO, L. C. O. Modelos tecno-assistenciais em saúde: da pirâmide ao círculo, uma possibilidade a ser explorada. Cad. de Saúde Públ., Rio Janeiro, v.13, n. 3, p. 469-478, 1997.

FLEURY, S. Paradigmas da reforma da Seguridade Social: Liberal-produtivista versus Universal-publicista. In: EIBENSCHUTZ, C. (Org.). Política de saúde: o público e o privado. Rio de Janeiro: Fiocruz, 1996. p. 69-94.

FOUCAULT, M. Microfísica do Poder. 18. ed. Organização, introdução e revisão técnica de Roberto Machado. Rio de Janeiro: edições Graal, 2003.

FREIRE, P. Pedagogia da autonomia: saberes necessários à prática educativa. 27. ed. Rio de Janeiro: Paz e Terra, 1996.

. Pedagogia do oprimido. 32. ed. Rio de Janeiro: Paz e Terra, 1987.

GIOVANELLA, L. Planejamento Estratégico em Saúde: uma discussão da abordagem de Mário Testa. Cad. de Saúde Públ., Rio de Janeiro, v. 6, n. 2, p.129-153, 1990.

; FLEURY, S. Universalidade da Atenção à Saúde: acesso como categoria de análise. In: EIBENSCHUTZ, C. (Org.). Política de saúde: o público e o privado. Rio de Janeiro: Fiocruz, 1996. p. 177-198.

GONZALES, R. I. C. et al. Gerenciamento de cuidado: um novo enfoque no cuidado à saúde. Rev. Latino-americana de Enferm., Ribeirão Preto-SP, v. 11, n. 2, p. 227-231, 2003.

GRAMSCI, A. Concepção dialética da história. 9. ed. Tradução de Carlos Nelson Coutinho. Rio de Janeiro: Civilização Brasileira, 1991.

HOUAISS, A. Dicionário Houaiss de língua portuguesa. Rio de Janeiro: Objetiva, 2001.

MATSUDA, L. M.; ÉVORA, Y. D. M.; BOAN, F. S. O método desdobramento da função qualidade (QFD) no planejamento do serviço de enfermagem. Rev. Latino-americana de Enferm., Ribeirão Preto-SP, v. 8, n.5, p. 97-105, 2000.

MATUS, C. Política, planejamento e governo. São Paulo: Hucitec, 1993.

MENDES, E. V. (Org.). Distrito Sanitário: o processo social de mudança das práticas sanitárias do Sistema Único de Saúde. 4. ed. São Paulo: Abrasco, 1999.

MISOCZKY, M. C. O campo da atenção à saúde após a Constituição de 1988: uma narrativa de sua produção social. Porto Alegre: Dacasa, 2002.

PAIM, J. S. Epidemiologia e planejamento: a recomposição das práticas epidemiológicas na gestão do SUS. Ci. Saúde Col., Rio de Janeiro, v. 8, n. 2, p. 557-567, 2003.

PEDROSA, J. I. S. A construção do significado do controle social com conselheiros de saúde no Estado do Piauí, Brasil. Cad. de Saúde Públ., Rio de Janeiro, v.13, n. 4, p.741-748, 1997. 
PEREIRA, A. A analítica do poder em Foucault: a arqueologia da loucura, da reclusão e do saber médico na Idade Clássica. Belo Horizonte: Autêntica, 2003.

PIOVESAN, M. F.et al.Vigilância Sanitária: uma proposta de análise dos contextos locais. Revista Brasileira de Epidemiologia, Rio de Janeiro, v. 8, n. 1, p. 83-95, 2005.

ROSO, A.; BUENO, S. N.; GUARESCHI, P. Planejamento na área de saúde: o poder em discussão. Saúde em Debate, Rio de Janeiro, v. 24, n. 54, p. 38-53, 2000.

SÁ, M. C. Subjetividade e projetos coletivos: mal-estar e governabilidade nas organizações de saúde. Ci Saúde Col., Rio de Janeiro, v. 6, n.1, p.151-164, 2001.

SARGENTINI, V.; NAVARRO-BARBOSA, P. Michel Foucault e os domínios da linguagem: discurso, poder e subjetividade. São Carlos-SP: Claraluz, 2004.

TEIXEIRA, C. F. A mudança do modelo de atenção à saúde no SUS: desatando nós, criando laços. Saúde em Debate, Rio de Janeiro, v. 27, n. 65, p. 257-277, 2003.

TESTA, M. Pensamento estratégico e lógica da programação: o caso da saúde. São Paulo: Hucitec, 1995.

. Pensar en salud. 3. ed. Buenos Aires: Lugar Editorial, 2004.

. Saber en salud: la construcción del conocimiento. Buenos Aires - Argenti-

na: Lugar Editorial, 1997. 


\section{CAPÍTULO 6}

\section{Sujeito e Práxis: tensão, conflito e complexidade na discussão do planejamento no campo da Saúde Coletiva $^{1}$}

Washington Luiz Abreu de Jesus

Marluce Maria Araújo Assis

Se a liberdade é que faz o homem, e o homem é o resultado de muitas determinações, o homem torna-se homem num processo de descoberta dessas determinações e de ação sobre elas. Esse se tornar homem significa que ele é essencialmente possibilidade, projeto. Poder tornar-se homem passa, portanto, pelo conhecimento de suas contradições e pela superação de suas próprias determinações.

Gadotti, 2001

\section{INTRODUÇÃO}

Para dar suporte teórico ao trabalho e a esse capítulo, utilizamo-nos das concepções de Matus (1993) e de Assis (1998) para definir o sujeito, enriquecidas pela visão de Merhy (2004). Também adotamos as concepções de sujeito de Testa (1997) e G. Campos (1992, 1994, 2000), compreendendo que esses autores nos auxiliam na compreensão do objeto em questão.

Para discutir a práxis, resgatamos as visões de Gramsci (1991) e Gadotti (2001), contextualizando-as com os trabalhos de Gallo (1995) e R. Campos (2003), pois entendemos que esses estudos buscaram um significativo aprofundamento teórico-conceitual sobre esta questão no âmbito do planejamento em saúde.

1 Agradecimento dos autores a Sisse Figueredo de Santana e Chaider Gonçalves Andrade pelas contribuições na revisão final do texto deste capítulo. 
No bojo da discussão do planejamento enquanto uma práxis relacionada aos sujeitos, apreendemos as concepções de tensão, conflito e complexidade. Para embasá-las, utilizamos Gramsci (1991), entendendo que as relações que se estabelecem entre os sujeitos são sempre dialéticas, sendo, portanto, tensas, conflitantes e complexas.

Para justificar a articulação entre sujeito e práxis no campo da Saúde Coletiva, nos inspiramos no trabalho de Minayo (2001), que discute as concepções acerca das relações entre esses elementos e a estrutura da sociedade. Com base nessa autora, resgata-se o sujeito como necessário, como ator das reformas e como partícipe das mesmas, para empreendê-las ou para desviá-las.

Como sujeito e práxis são um híbrido indissociável, lançamos mão da Pedagogia da libertação de Freire $(1987,1996)$, cujos propósitos coadunam com aquilo que já discutimos nas outras categorias - a construção da autonomia dos sujeitos; e da Pedagogia da práxis de Gadotti, que, inspirada na dialética, institui-se como uma ação para a transformação, sem esconder o conflito, a contradição. Compreendemos que as propostas teórico-metodológicas apresentadas para o planejamento no campo da Saúde Coletiva podem ter sido influenciadas pelos ideais libertários dessa "Pedagogia Transformadora".

Para dar sustentação a essa análise, procuramos desenvolver uma proposta assentada na Pedagogia, entendendo que a construção dos sujeitos é um movimento determinado pedagogicamente. Eles podem se constituir como alienados ou livres a partir de uma intervenção pedagógica cuja luta tem como pano de fundo a defesa da vida: para a manutenção do status quo, ou para a transformação social.

Por fim, estabelecemos um link entre a teoria e a prática, discutindo os sujeitos do planejamento à luz da produção científica da área de PP\&G em saúde, produzida e divulgada em periódicos de Saúde Coletiva no período 1990-2010. 


\section{DEFINIÇÃO DOS TERMOS: O MOVIMENTO DE CONFORMAÇÃO TEÓRICA}

Aqui, procuramos estabelecer uma aproximação com os termos que pretendemos trabalhar, partindo das definições de sujeito/ator social, identificando suas diferentes formas de apresentação, até as concepções da práxis, resgatando os conceitos já explicitados anteriormente, ampliados com a visão de teóricos da área da Educação e da Saúde Coletiva. Discutimos também os conceitos de tensão, conflito e complexidade, unidades importantes para a composição da análise.

Preliminarmente, tomaremos as considerações de Matus (1993) acerca dos atores sociais, tendo em vista ter sido ele o idealizador do Planejamento Estratégico Situacional, elemento primordial na inserção da discussão do sujeito no campo do planejamento em saúde. Para esse autor, não há distinção entre sujeito e ator, ao contrário, o sujeito é incorporado pelo conceito de ator - uma personalidade, organização ou agrupamento humano que, de forma estável ou transitória, tem a capacidade de acumular força, desenvolver interesses e necessidades, e atuar produzindo fatos na situação.

Misoczky (2002), ao analisar o pensamento de Matus, considera que o ator social deve preencher alguns requisitos para se instituir como tal. São eles: possuir ação criativa; ter um projeto que orienta sua ação; ter capacidade de acumular e (des) acumular forças; ser capaz de produzir novos fatos; participar do jogo social; ser organizado; ter presença forte no campo social; e apresentar-se como um ator-pessoa e como um ator-grupo.

Assis (1998) utiliza os termos: sujeitos sociais, sujeitos coletivos, atores sociais e agentes sociais com o mesmo significado, mesclados pelas ideias de Sader (1991) e Matus (1993). Para a autora, esses são portadores de projetos (ainda que não sejam explícitos), e que a ação humana é uma categoria situacional, suscetível a intencionalidade ou reflexão dos distintos atores que se relacionam na produção dessa ação. É na organização institucional que são produzidos os sujeitos coletivos/sociais, sua identidade e suas práticas, seus interesses e vontades, constituindo-se em espaços de 
luta em defesa de um projeto (pela manutenção da ordem ou transformação social).

Testa (1997) parte da concepção de que o sujeito da vida se transforma em epistêmico, discorrendo sobre as categorias da determinação e da constituição, para discutir os sentidos e os significados hermenêuticos da relação ciência/vida.

Alcança o sujeito avaliador, cuja relação com a ciência lhe permite questionar, avaliar, transformar-se internamente com a ruptura epistemológica estabelecida com o senso comum. $\mathrm{O}$ sujeito avaliador é aquele que protagoniza a autotransformação por meio do conhecimento. Alcança também o sujeito público, entendido como aquele que, de posse do conhecimento, divulga esse conhecimento por meio da linguagem e constrói a intervenção sobre as práticas. A reconstituição das práticas e sua aplicação conduzem o sujeito público a uma transformação externa, validando-se e se estabelecendo como um sujeito da vida reconstituído, cujo conhecimento promove mudanças significativas nas práticas cotidianas, criando um "saber fazer" e um "saber como" que pode ajudar na transformação da sociedade.

Para Merhy (2004), os sujeitos são protagonistas de processos de transformação, por meio da produção do conhecimento, da ação e da construção intencional de um saber que dê sentido para agir em determinados campos da atividade humana. Para ele, os sujeitos podem ser interessados, implicados, militantes, políticos, pedagógicos, técnicos e epistêmicos. Revelam-se a partir do seu próprio agir mediante os desafios que se constituem no cenário protagônico em que atuam e de acordo com as posições que ocupam nesse cenário, seja individual ou coletiva, particular ou pública.

As concepções apresentadas por Merhy (2004) ampliam as ideias apresentadas por Testa (1994), que discorre de forma instigante sobre a produção do sujeito no campo do conhecimento. Para Testa, o sujeito é um produto do conhecimento, construído na interação entre as práticas da vida cotidiana e a positivação das ciências. O sujeito de Testa se desenvolve ao longo da história e se transforma a partir do encontro com as ciências, estabelecendo com ela momentos de objetivação e subjetivação, numa dupla transformação (interna e externa) do seu conhecimento. 
Campos contemporiza sobre a questão do sujeito no momento em que desenvolve o "método da roda". Apresenta como um dos eixos de conformação desse método o fortalecimento dos sujeitos e a construção da democracia institucional, engendrados por um elemento denominado "fator Paidéia"2. Esse elemento seria ativado na ampliação da capacidade de análise e de intervenção dos sujeitos e dos grupos, produzindo um status democrático de reforma social, resultado da práxis e do compartilhamento de poder.

O sujeito de G. Campos (2000) é um sujeito capaz, imbuído da habilidade e da potência para compor consensos, alianças e implementar projetos. É um sujeito ético, capaz de instituir compromissos e de enfrentar a questão da dominação com perspicácia e altruísmo. Um sujeito materializado nas relações de trabalho, dos desejos e das necessidades, capaz de produzir valores de uso. Um sujeito da práxis, misturado com o sujeito do gozo ou ao sujeito do prazer.

E por falar em práxis, passamos a discuti-la agora como o outro elemento constitutivo da análise. Partimos do resgate das considerações de Gramsci (1991) sobre a filosofia da práxis. Para ele, “[...] a filosofia da práxis só pode se apresentar em uma atitude polêmica e crítica, como superação de uma maneira de pensar precedente e de um pensamento concreto existente". (GRAMSCI, 1991) É uma contraposição ao senso comum, entendido não como um conhecimento comum, mas como um status comum de interpretação filosófica, assentada sob as concepções paradigmáticas da hegemonia.

A filosofia da práxis é uma filosofia de libertação, que dá suporte às iniciativas de luta das sociedades. Um movimento dialético, constituído na base do questionamento do novo sobre o velho. No questionamento da manutenção da ordem.

Gramsci (1991) esclarece que existe uma relação entre hegemonia e pedagogia, afirmando que

2 Paidéia é uma noção originária da Grécia Clássica e indica formação integral do ser humano. A gestão e as práticas profissionais têm a capacidade de modificar os padrões dominantes de subjetividade e, portanto, alterar o modo de ser dos sujeitos. Tem, portanto um potencial pedagógico e terapêutico, seja para criar dependência e impotência, seja para ampliar a capacidade de análise e de intervenção das pessoas e dos coletivos. (CAMPOS, G., 2000) 
[...] toda relação de hegemonia é necessariamente uma relação pedagógica, que se verifica não apenas no interior de uma nação, entre as diversas forças que a compõem, mas em todo campo internacional e mundial, entre conjuntos de civilizações nacionais e continentais [...]. O princípio teórico-prático da hegemonia tem importância gnosiológica ${ }^{3}$, psicológica e moral.

A inversão da práxis se revela na contraditória hegemonização ideológica resultante de uma pedagogia alienante.

Partindo do princípio que toda relação de hegemonia é pedagógica e que uma pedagogia alienante se traduz na inversão da práxis, nos aproximamos de Gadotti (2001) para discutir uma proposta de contra-hegemonia cujo ideal se assenta na pedagogia da práxis. Verdadeiramente, por ser contra-hegemônica é que se intitula Pedagogia da práxis.

Gadotti (2001) define a práxis como o resultado da atuação histórica dos indivíduos, identificada a partir do trabalho do homem sobre as contradições que se apresentam mediante o seu processo de formação integral, e para que o indivíduo seja reconhecido como homem é preciso que ele seja livre, um sujeito em situação de plena liberdade, atuando sobre sua realidade com altivez e capacidade de intervenção. Trata-se de um sujeito livre e, portanto, propagador dos ideais de liberdade.

A Pedagogia da práxis é a pedagogia da liberdade, que, aliada à Pedagogia da Libertação se configura como a Pedagogia da Transformação, um status re-significado de pedagogia para a construção de sujeitos e de coletivos. É uma pedagogia inspirada no conflito e na contradição dialética da vida, na ação transformadora e na capacidade de intervir e aprender com a realidade em processo. A Pedagogia da Transformação, portanto, não se esgota.

Gallo (1995) discute a práxis como uma categoria analítica do planejamento em saúde. Para ele, a práxis é entendida como uma atividade voltada para o desenvolvimento autônomo e emancipador do outro, e, consequentemente, de si mesmo e da sociedade - uma aproximação entre

3 Gnosiológico se refere à teoria geral do conhecimento humano, voltada para uma reflexão em torno da origem, natureza e limites do ato cognitivo, frequentemente apontando distorções e condicionamentos subjetivos em um ponto de vista tendente ao idealismo, ou sua precisão e veracidade objetivas, em uma perspectiva realista. (GALLO, 1995) 
as realidades subjetiva e objetiva, compreendidas historicamente em momentos pretéritos e momentos presentes.

Os momentos pretéritos, segundo ele, traduzem os acúmulos, as motivações e as indagações que levam o sujeito a se questionar e a questionar suas realidades. Os momentos presentes são aqueles em que, na consolidação de uma práxis construtivista ${ }^{4}$, se constroem subsídios para responder às indagações da práxis pretérita ${ }^{5}$.

Toda práxis, segundo Gallo (1995) se constrói por meio do enfrentamento e da disputa pela hegemonia, travada pelos diversos atores e diversos discursos. A Reforma Sanitária Brasileira e sua trajetória de construção político-ideológica, na concepção do autor, se constituíram num movimento paradoxal de construção de consciência sanitária e luta contra a hegemonia econômica, revelando a necessidade de se discutir, no plano das ideias, as contradições entre os ideais de transformação e os conservadores; entre a mudança e a manutenção da ordem; entre a inovação tecnológica e a renovação da prática.

Para finalizar seu trabalho, Gallo discorre sobre a razão, o planejamento, os mitos e a emancipação como elementos de construção da práxis na área de saúde. Parte do princípio que o planejamento em saúde se constitui, em parte, como instrumento de conservação da ordem social, sendo, consequentemente, incapaz de emancipar, dada a sua racionalidade sistêmica e seu caráter intrinsecamente conservador, o que não se pode confundir com um suposto caráter reacionário.

Os mitos do desenvolvimento, da neutralidade científica, da teleologia redentora e da política como ciência funcionam como o arcabouço constitutivo do planejamento, na visão do autor. Mesmo quando ideologizado, o planejamento não se transforma em política, apenas assume um papel político, capaz de estabelecer processos organizativos para a organização dos modos de produção, das forças produtivas e das relações de produção, instrumentos de dominação e de alienação.

4 Práxis construtivista é o resultado das reflexões sobre a práxis pretérita. O momento em que, subsidiado pelos seus pressupostos teóricos, um pesquisador delineia seus questionamentos sobre o seu objeto na busca de uma compreensão objetiva. (GALLO, 1995)

5 Práxis pretérita nada mais é do que uma situação histórica anterior e específica, geradora de um determinado problema, que aguça e inquieta um pesquisador para aproximação a um objeto. (GALLO, 1995) 
R. Campos (2003) apresenta a práxis como uma possibilidade para se sair da armadilha da técnica, resgatando a noção de projeto como uma intenção para a transformação do real, levando em consideração as condições reais e animando a realidade.

O planejamento pode ser uma técnica quando se preocupa da elaboração de planos, um formato técnico já não nos basta para estimularmos os grupos humanos a formular projetos, e isso porque nem os fins nem os meios podem ser estabelecidos com certeza com antecedência, nem há saber prévio que possa resolver essa questão. (CAMPOS, R., 2003, p. 97)

A autora utiliza as concepções de Castoriadis (1986) para definir práxis como uma atividade consciente, que só pode existir na lucidez. Na práxis, a atividade precede a elucidação, tendo como última instância a transformação daquilo que está dado. O objeto próprio da práxis, portanto, é o novo. Planejar mudanças para os serviços de saúde nada mais é que interferir e mobilizar os valores de uso dos sujeitos, o que necessariamente conduziria os planejadores a um diálogo necessário com os saberes da "clínica”.

A práxis do planejamento na área de saúde, portanto, deve ser um dispositivo mobilizador dos sujeitos na busca da consolidação da "clínica" como uma prática transformadora, que produza mudanças concretas nas condições de vida das pessoas. Um desafio, já que os sujeitos planejadores, na essência, têm sua formação alicerçada na fragmentação tecnocrática, afastada das questões advindas das modelagens clínicas e da reflexão sobre a sua própria práxis. (CAMPOS, R., 2003)

Minayo (2001), ao refletir sobre o determinismo e o protagonismo histórico dos sujeitos nas estruturas, apresenta a dimensão da práxis como definidora do processo de transformação da realidade. Os sujeitos, constituídos a partir da interação entre a práxis, a natureza e a sociedade, estabelecem sua autonomia no mundo da vida por meio de trocas intersubjetivas que se concretizam no universo da complexidade social. 0 cuidado que devemos ter, entretanto, segundo a autora, é não nos deixarmos iludir pela falsa totalidade estabelecida pela práxis objetivada, consequência da hegemonização de práticas, que, em linhas gerais, contribuem substancialmente para o apagamento dos sujeitos, um fenômeno social de alienação e de aprisionamento da consciência. 
Para finalizar essa discussão, retornamos a Gramsci (1991) para definir as relações entre os sujeitos e a práxis como tensas, conflituosas e complexas. Já discutimos a concepção trazida por R. Campos (2003) que trata da tensão-contradição do planejamento no tocante às intencionalidades declaradas das organizações e os desejos daqueles que as constituem.

Gramsci (1991) define as relações humanas como complexas por natureza, se desenvolvendo no espaço tenso e contraditório das lutas pela hegemonia. Uma complexidade pedagógica relacionada a uma dialética intelectual-massa, ou seja, uma contradição entre o saber científico e o saber comum; entre o poder ideológico e o poder empírico; entre dominadores e dominados.

O espaço da dialética é o espaço das disputas entre os sujeitos. É o espaço da reafirmação da práxis, do fortalecimento da contra-hegemonia.

Trabalhar a questão do sujeito com foco sobre a práxis, portanto, nos conduz ao entendimento que a complexidade do sujeito e de suas relações, em que pesem todos os elementos que a permeiam, é uma possibilidade a ser compreendida se, e somente se, nos abrirmos para o fato de que o sujeito é um ser subjetivo, que possui uma realidade subjetiva e vive uma subjetividade tal que, se não for decifrada, levará qualquer projeto ao ocaso. A pedagogia aplicada sobre esse sujeito deve ser adequada para produzir nele a transformação suficiente para que ele perceba seu papel enquanto sujeito da práxis na luta em defesa da vida.

Constituir sujeitos é um objetivo a ser perseguido por aqueles que acreditam que as libertações ideológica, filosófica e política são o caminho para a construção de uma sociedade justa e constituída por todos e para todos.

\section{A CONSTRUÇÃO PEDAGÓGICA DO SUJEITO SOCIAL NO CAMPO DO PLANEJAMENTO EM SAÚDE: UMA PROPOSTA DE ANÁLISE TEÓRICA}

Diante de nós se põe um grande desafio: trabalhar a questão do sujeito no universo do planejamento em saúde, sem incorrer na obviedade já instituída. Debruçamo-nos em leituras sobre o sujeito no campo da Saúde Coletiva e nos deparamos com discussões epistemológicas, filosóficas e 
ideológicas, cujos objetivos concretos refletem, no nosso entendimento, uma discussão consistente, principalmente nos trabalhos de Testa (1994), G. Campos (2000) e Merhy (2004).

Os trabalhos desses autores conformaram o ponto de partida adotado por nós para desenvolver a proposta analítica desse capítulo. Entretanto, precisávamos de algo mais. Precisávamos do resgate da discussão do poder, feita no capítulo anterior, aliando a dimensão epistemológica, ideológica e filosófica, dada por Testa (1994); a dimensão subjetiva, de Foucault (2003); a dimensão técnica/tecnológica, de Merhy (2004); e a dimensão política, de G. Campos (1992, 1994, 2000). Para conformar as dimensões da práxis re-significada faltava-nos, entretanto, a dimensão da pedagogia, já que entendemos que construir sujeitos é uma prática eminentemente pedagógica.

Buscamos, então, alicerçar nossa necessidade na leitura de alguns trabalhos de Paulo Freire, o mestre pensador. Descobrimos, na Pedagogia do oprimido (1987), o quarto elemento: o pedagógico. Esse elemento, ainda incompleto, era o mote para compreender as outras dimensões, sintetizadas na dimensão da práxis.

Mas percebemos que mesmo tendo encontrado o quarto elemento, ainda estávamos com uma dívida com a totalidade: onde estaria o ponto de conexão entre essa dimensão pedagógica e a dimensão da práxis re-significada? Havíamos encontrado a Pedagogia da Libertação. Precisávamos agora encontrar a Pedagogia da práxis.

E encontramos, pelo menos, neste momento provisório.

No trabalho de Gadotti (2001), intitulado Pedagogia da práxis, encontramos o complemento para o quarto elemento, que foi desenvolvido pelo autor a partir de discussões com o mestre pensador Paulo Freire, durante o seu exílio, na Europa.

Estava posto o ponto de conexão, aquilo que nos possibilitaria avançar na nossa caminhada com um modelo ampliado de análise que pudesse dar conta dessa questão com maior completude. Agora era só encarar o desafio, buscando a compreensão do sujeito a partir de uma concepção pedagogicamente construída, em cujas bases se assentam toda a visão da 
sociedade: a busca de uma totalidade concreta, explicitada no quadro a seguir (Quadro 01).

\section{QUADRO 01: Uma análise pedagógica da constituição dos sujeitos}

\begin{tabular}{|c|c|}
\hline PEDAGOGIA DA ALIENAÇÃO & PEDAGOGIA DA LIBERTAÇÃO \\
\hline $\begin{array}{l}\text { PRÁTICAS, ESTRUTURAS E FORMAÇÕES } \\
\text { CONSERVADORAS }\end{array}$ & $\begin{array}{c}\text { PRÁTICAS TRANSFORMADORAS, ESTRUTURAS } \\
\text { REVOLUCIONÁRIAS E } \\
\text { FORMAÇÕES LIBERTADORAS }\end{array}$ \\
\hline SUJEITOS DA ALIENAÇÃO & SUJEITOS DA PRÁXIS \\
\hline SUJEITOS DA OPRESSÃO & SUJEITOS DA LIBERTAÇÃO \\
\hline $\begin{array}{c}\text { UTILIZAÇÃO DOS RECURSOS DA FORÇA, } \\
\text { DO SILENCIAMENTO, DA PRESCRIÇÃO E } \\
\text { DO PODER }\end{array}$ & $\begin{array}{c}\text { LIBERTAÇÃO PELA TÉCNICA, } \\
\text { PELA PRÁTICA SOCIAL } \\
\text { E PELA SUPERAÇÃO DA } \\
\text { CONTRADIÇÃO OPRESSORES-OPRIMIDOS }\end{array}$ \\
\hline SUJEITOS ALIENADOS & SUJEITOS LIVRES \\
\hline \multicolumn{2}{|c|}{ TOTALIDADE CONCRETA } \\
\hline \multicolumn{2}{|c|}{ LUTA EM DEFESA DA VIDA } \\
\hline IDEAL CONSERVADOR & IDEAL LIBERTÁRIO \\
\hline AÇÃO DOMINADORA & AÇÃO LIBERTADORA \\
\hline CONCEPÇÃO ANTIDIALÉTICA & CONCEPÇÃO DIALÉTICA \\
\hline LUTA PELA MANUTENÇÃO DA ORDEM & $\begin{array}{c}\text { LUTA PELA MUDANÇA OU TRANSFORMAÇ̃̃O } \\
\text { SOCIAL }\end{array}$ \\
\hline MANUTENÇÃO DO STATUS QUO & TRANSFORMAÇÃO DA REALIDADE \\
\hline
\end{tabular}

Adaptado das concepções de Albuquerque (1986); Matus (1993); Testa (1997, 2004); G. Campos (2000); Foucault (2003); Bobbio (2005); Freire (1979, 1987, 1996) e Freire e Shor (1986).

Para nós, o universo dos sujeitos é resultante de intervenções pedagógicas sobre os indivíduos, os grupos e a sociedade. Concordamos com G. Campos (2000) quando discute que a constituição do sujeito é um misto de sujeito do gozo com sujeito do prazer, pois o que está em jogo é a luta pela vida, e nessa luta os sujeitos atuam movidos pelo seu gozo e pelo seu prazer, seja no sentido individual ou coletivo. Concordamos com ele 
também quando, discutindo a co-produção de sujeitos e coletivos, identifica as dimensões interna e externa como determinantes da formação do compromisso; da elaboração e gestão de contratos e de projetos; e da transformação da práxis.

A construção pedagógica dos sujeitos é uma resposta epistemológica que pretendemos dar. Uma contribuição através de um modelo de análise que aproxime o sujeito da prática e da pedagogia.

Para isto, partimos da concepção que pedagogias alienantes se constituem no objeto das estruturas e superestruturas conservadoras, que, utilizando-se dos recursos da força, do silenciamento, da prescrição e do poder, operados pelos sujeitos da alienação e da opressão, produzem sujeitos alienados, cuja totalidade concreta de sua vida é a luta pela manutenção da ordem. Em contraposição, pedagogias libertárias se constituem no objeto das estruturas revolucionárias, que se utilizam dos recursos da técnica e da prática social para superar a contradição opressor-oprimido, isto é, para produzir sujeitos livres, cujos objetivos de vida se resumem na transformação da realidade.

Os sujeitos da alienação e sua concepção de vida antidialética produzem, através de sua ação dominadora e de sua pedagogia, o sujeito alienado. Os sujeitos da práxis - da libertação - produzem, por conseguinte, sujeitos livres, através da sua ação libertadora e sua concepção de vida dialética. 0 primeiro trabalha com a lógica da hegemonia e o segundo com a lógica da contra-hegemonia e da anti-hegemonia, corroborando com o explicitado por Gramsci (1991), que identifica a relação entre o sujeito e a práxis como complexa.

No campo da Saúde Coletiva, a testificação da abordagem pedagógica como fundamental na determinação do sujeito nos permite intuir que o planejamento em saúde pode se dar em duas subdimensões analíticas: a relacionada à manutenção do status quo, como resposta à pedagogia da alienação; e a relacionada à transformação social, como resposta à pedagogia da libertação e da transformação. Neste sentido partiremos agora para o último movimento analítico concreto - o estudo das subdimensões do planejamento em saúde no Brasil (1990-2010) com base na questão do sujeito e sua relação com a práxis na luta pela defesa da vida. 


\title{
PLANEJAMENTO PARA A MANUTENÇÃO DA ORDEM: A CONSTRUÇÃO DO SUJEITO ALIENADO A PARTIR DA AÇÃO DOMINADORA DO SUJEITO DA OPRESSÃO
}

Minayo (2001) nos convida a uma reflexão importante acerca da finalidade do trabalho no campo da saúde:

\begin{abstract}
No trato dos enfermos, o campo da saúde sempre se importou mais com a lógica da enfermidade que com os sujeitos. Também nas organizações dos serviços de saúde, no seu planejamento e avaliação, a ênfase tem sido muito maior nos métodos que conferem relevâncias às relações entre funções, papéis e relações técnicas. Ainda quando o planejamento estratégico é incluído no campo organizacional, seus objetivos são preferencialmente voltados para perceber a vontade dos diferentes atores, a fim de confrontá-los e dominá-los, mostrando a prática autoritária da organização da saúde coletiva. (MINAYO, 2001)
\end{abstract}

Ao afirmar que o campo da saúde se preocupou mais com a lógica da enfermidade que com os sujeitos, a autora demonstra que, na sua concepção, o foco da ação em saúde tem sido a doença. Ao dizer que o processo de constituição e acompanhamento dos serviços de saúde dá ênfase a funções, papéis e relações técnicas, explicita que o mais importante para muitos daqueles que pensam a saúde é desenvolver técnicas para sistematizar as atividades das pessoas com o objetivo do combate à enfermidade. Quando trata do planejamento estratégico, a autora também identifica que, em que pesem os movimentos de interação com os atores sociais, o foco no jogo é, muitas vezes, a dominação do adversário, configurando uma competição que dificulta a possibilidade de interações subjetivas.

Iniciamos, então, sob o olhar dessas considerações, o movimento de aproximação com a subdimensão do planejamento como instrumento para a manutenção da ordem, entendendo que, no contexto científico, não existem verdades absolutas. Procuramos discorrer acerca das impressões que tivemos no tocante à posição dos sujeitos ante o planejamento, principalmente nos últimos vinte anos. Temos consciência que o tema não se esgotará com esta análise, haja vista a sua complexidade epistemológica e sua diversidade de interpretações possíveis. 
De fato, o que vivenciamos, na prática, é uma desarticulação teórico-prática, que se revela como resultado de um "casamento" entre as ideologias totalizantes e as práticas transformadoras, culminando num conflito, cuja tradução objetiva é identificada no termo freiriano da "contradição estabilidade-mudança": um polissêmico que sintetiza dialeticamente as lutas no campo da hegemonia e da contra-hegemonia.

Freire (1979), Freire e Shor (1986), ao discutir os conceitos de sociedade, estabelece que, nas sociedades fechadas, os sujeitos são relegados à categoria de "massa", dominada pelas elites, que prescreve suas determinações conforme suas práticas predatórias, a partir de estruturas rígidas e autoritárias, que corroboram com a ideia de dicotomia do trabalho e da atividade intelectual. Para essas sociedades, segundo o autor, se constitui a sociedade-sujeito, detentora da capacidade de decisão, e a sociedade-objeto, dominada, periférica e não reflexiva. Trata-se de uma sociedade alienada, resultante da falta de consciência e de autenticidade; da vergonha de se encarar a realidade e de se assumir; do desconhecimento de si mesmo e da importação de soluções para atacar problemas nativos.

As sociedades alienadas são um campo fértil para a disseminação das ideologias totalizantes e dos ideais conservadores, pois os sujeitos que a compõem não se incluem no processo de discussão social, ocultando-se na sua dimensão simbólica por traz da ideologia dominante em decorrência do medo ao enfrentamento da alienação. É nelas que se estabelece a contradição estabilidade-mudança, identificada por Freire (1979) como o processo permanente de luta da hegemonia para se manter. De fato, é nessas sociedades que se instituem os processos antimudança: movimentos de manutenção da ordem, motivados pelo medo da contestação à ordem instituída.

Uma sociedade alienada é o mundo da vida dos sujeitos alienados: produtos da pedagogia da alienação; produtos da ação dos sujeitos da opressão. São o resultado concreto da ação de práticas pedagógicas totalizadoras, pautadas na educação bancária, cujos princípios apontam para a subserviência, subsapiência, submissão e disciplina.

O planejamento, como instrumento de manutenção da ordem com a produção de sujeitos alienados, tem o objetivo concreto de responder a 
uma totalidade concreta cuja luta pela vida se assenta na manutenção do status quo, pois tem como pano de fundo a utilização dos recursos da força, do silenciamento, da prescrição e do poder.

Tratar dessas questões no campo da Saúde Coletiva é como manipular uma colmeia: um exercício perigoso e doce. É nesse campo que se revelam as mais doces surpresas e as mais perigosas constatações.

Gallo (1995) constatou que o planejamento, na forma como concebido, distanciava-se da práxis e se instituía como um instrumento de conservação da ordem social, sendo, consequentemente, incapaz de emancipar a sociedade e o sujeito, dada a sua racionalidade sistêmica e seu caráter intrinsecamente conservador.

Os dilemas apresentados pelo autor entre a necessidade de transformação da realidade e a conservação da ordem no tocante à operacionalização dos ideais da Reforma Sanitária no campo da saúde no Brasil, demonstram a grande contradição do planejamento para essa área. Uma contradição que se revela na dissociação entre teoria e prática - uma dissociação que, na verdade, se concretiza como uma falsa totalidade, assentada nos ideais de liberdade, porém submetida ao domínio ideológico da dominação e da alienação.

A teoria exigia dos reformistas denúncias às limitações estruturais postas pelo capitalismo e a necessidade de sua superação pela consciência sanitária, de classe, da interação. A prática omitia essa denúncia e preconizava a dialética do possível e o agir racional com respeito a fins. De fato, uma defasagem entre a teoria e a prática, que acabou por desencadear a proeminência da dimensão instrumental, construindo uma nova práxis - a práxis conservadora. (GALLO, 1995, p. 48)

Os paradoxos e antagonismos dessa realidade demonstravam para o autor, além de tudo, um antagonismo que se traduzia numa tensa e conflituosa relação entre concordâncias e divergências táticas e estratégicas, que, no bojo da reforma proposta, tinham como projeto comum a superação subjetiva da objetividade em direção a uma nova objetividade. Ou seja, as lutas pela hegemonia ideológica entre reforma e contra-reforma sanitárias instituíam, no seio do planejamento em saúde, um nicho de contradições que tinha como cenário a dicotomia teoria-prática. Enquanto uns 
buscavam alicerçar seus ideais na pedagogia libertadora para construir sujeitos livres, outros se utilizavam da pedagogia da alienação para construir sujeitos subordinados a suas concepções e preparados para responder sem questionar as práticas hegemonizadas no contexto histórico.

O conservadorismo não assume, nesse contexto, a ideia de manutenção do status político, mas sim de manutenção do status ideológico-filosófico, que, sob os auspícios do poder, paradoxalmente contribui para a manutenção do status quo. As práticas hegemonizadas se legitimam como práticas conservadoras vis a vis seus conceitos básicos utilizarem o agir racional com respeito a fins - uma concepção teleológica que, no contexto apresentado, aponta para o planejamento normativo reconstituído.

Apesar dessas perigosas constatações, as "doces surpresas" se revelam em meio aos antagonismos axiológicos. A ação normativa legitimada e a ação teleológica fazem despertar a rediscussão do sujeito - um indivíduo que, até então, se colocava e era colocado de fora do planejamento, como um ser externo, alienígena. 0 sujeito alienado, resultado de uma pedagogia alienante, excluía-se como sujeito do processo do planejamento, dando lugar ao instrumento. O sujeito amorfo, coletivizado, impessoal, se traduzia como resultado da pedagogia alienante, cuja concepção antidialética refletia o que Freire ${ }^{24}$ refutava em seus trabalhos e discussões: o silenciamento e o apagamento ideológico, filosófico e processual de construção de uma identidade pedagógica.

O silenciamento é a negação do diálogo. $O$ apagamento ideológico e filosófico é a negação da autonomia e da liberdade. O apagamento processual é a negação da história. Sem diálogo, sem autonomia, sem liberdade e sem história não há sujeito, sim, um produto amorfo de intencionalidades, cuja expressão de existência é a alienação.

Ao identificarmos o planejamento em saúde conforme as concepções explicitadas no capítulo 2 - técnica para 'intervir' e 'avaliar' sistemas e serviços de saúde; prática social transformadora de sujeitos e coletivos; subsídio para a gestão democrática e para as mudanças; prática estruturada para a organização de sistemas e serviços de saúde; método de ação governamental para a tomada de decisões; instrumento e atividade do processo de gestão das organizações; meio de intervenção em ambientes 
complexos; meio de ação comunicativa; mediação entre a instrumentalidade e a subjetividade - estamos trabalhando com a perspectiva de construção de um novo sujeito para o planejamento: livre, (des)alienado, autônomo, capaz de reagir ante o status quo e propor um processo de mudança que supere a ação dominadora do sujeito da opressão.

Aí está a "doce descoberta"!

No campo da Saúde Coletiva, o sujeito passou a expressar sua indignação com a sua situação de alienação. Passou a gritar por um planejamento que o incluísse como parte integrante e intrínseca, como partícipe, como membro do todo a ser planejado. Conforme foi explicitado por Teixeira (1999): um planejamento que articule a dimensão da teoria, da prática numa única totalidade - a totalidade fundamental do ser humano.

\section{PLANEJAMENTO PARA A MUDANÇA OU TRANSFORMAÇÃO SOCIAL: A COŅSTRUÇÃO DO SUJEITO LIVRE A PARTIR DA AÇÃO LIBERTÁRIA DO SUJEITO DA PRÁXIS}

No vácuo da "doce descoberta" explicitada na seção anterior, assumimos a última subdimensão de análise desse capítulo, tratando a questão do sujeito a partir de uma visão mais transformadora da sociedade.

Para dissertar sobre o universo da transformação social, faremos uma recapitulação das concepções já apresentadas nesse capítulo, resgatando a discussão de Freire (1879, 1987, 1996), Freire e Shor (1986), G. Campos (1992, 1994, 2000) e Minayo (2001). Por fim, trabalharemos com Teixeira (1999) e com R. Campos (2003), com a explicitação daquilo que apreendemos como enfoques do planejamento para a transformação da realidade, finalizando a análise.

Paulo Freire, em seus trabalhos acerca de uma nova pedagogia, nos permite encontrar um universo diferenciado de saberes que nos possibilitam alcançar níveis de liberdade que demonstram o poder transformador de suas palavras.

Em seu livro Educação e mudança, Freire discute que o processo de mudança da sociedade é um compromisso dos sujeitos da práxis, denominados trabalhadores sociais. Para ele, os homens-mundo libertam-se 
da alienação quando se tornam capazes de compreender suas realidades, identificando na sua própria ação, objetiva no tempo, as possibilidades de estabelecer novas circunstâncias. Esse homem-história, também identificado como homem-realidade, relaciona-se com sua sociedade através de sua consciência crítica e promove uma sucessão de mudanças, que culminam por movimentar o cosmos na direção da transformação. Os trabalhadores sociais, comprometidos com o processo de mudança, posicionam-se no jogo dialético mudança-estabilidade para superar a contradição estabilidade-mudança.

Queremos dizer que, na luta pela vida travada na busca da hegemonia, os sujeitos da transformação estabelecem diferenciais na sua ação, que lhes permitem inverter a relação dominação/subordinação, passando a liderar um processo reacionário que tem como objetivo alterar as estruturas sociais e estabelecer uma nova ordem - a transformação social.

Como diria Freire (1979): o objetivo da ação da mudança é a superação de uma totalidade por outra, em que a nova não continue apresentando a contradição estabilidade-mudança, que constitui a duração da estrutura social e também o histórico-cultural. A estrutura social é uma totalidade porque é constituída por partes que se interagem entre si na dimensão histórica da sociedade.

Trabalhadores sociais são sujeitos de transformação social. Portanto são responsáveis pela (des)alienação e pela autonomização dos outros sujeitos. São sujeitos livres, que atuam nos serviços de sua liberdade para construir liberdades. Atuam com sua totalidade subjetiva e histórica para construir um ideal libertário capaz de intervir sobre a realidade subjetiva do outro e fazê-lo ressurgir, desvelando-se, despindo-se da couraça da alienação.

Nessa visão, G. Campos (2000) apresentou-nos o "método da roda" como uma possibilidade de intervenção sobre os trabalhadores sociais, por ele denominados como "sujeito-da-práxis misturado ao sujeito do gozo e ao sujeito do prazer" - uma construção semântica que sintetiza todas as dimensões de um sujeito na sua totalidade concreta: uma práxis; um contentamento; um prazer. 
Esse autor, apesar de desenvolver suas considerações no campo das discussões sobre o trabalho, não perde de vista que o sujeito é um ser que está no mundo, que vive no mundo e que vive do mundo. Um ser que, apesar de sua dimensão biológica, também é subjetividade; que apesar da sua subjetividade também é relação; que apesar de ser relação também é luta; que apesar de ser luta também é consenso e dissenso, e, como tal se comporta para estabelecer o equilíbrio de suas relações para co-produzir necessidades.

Minayo (2001), ao discorrer sobre o sujeito como estrutura epistemológica, passeia pela história reconhecendo a intrínseca relação existente entre esse sujeito e as estruturas da sociedade. E mais, chega até a propor um sujeito coletivo, que, na sua dimensão epistemológica, se desprende do campo biológico e transcende ao campo estrutural, construindo o "sujeito-coletivo-da-saúde": a sociedade perpassada por conflitos de interesses sociais e políticos, e pelos núcleos de consenso e de identificação.

No campo da Saúde Coletiva, o desenvolvimento daquilo que podemos chamar "discussão do sujeito da transformação no planejamento" perpassa a discussão dos enfoques contra-hegemônicos e anti-hegemônicos que se estabeleceram como marcos na história. Uma abordagem que resgata o ponto de partida do nosso caminhar - a questão do planejamento enquanto uma possibilidade a ser construída.

Um retorno à história, porém vivenciada a partir de uma práxis. Para recontar. Re-significar. De certa forma, resgatar os enfoques num movimento responsável de reconstrução, respeitando as particularidades sem deixar de expor as fragilidades, os limites e as potencialidades. Um movimento que nos remete aos trabalhos de Teixeira (1999) e de R. Campos (2003), sujeitos que, no nosso entendimento, abraçaram a causa da interpretação do planejamento, ainda que com enfoques diferenciados; e avançaram para a explicação com uma totalidade que, somente por meio dos recursos da hermenêutica, se consegue alcançar.

Esse encontro hermenêutico tem como explicitado por Santos ${ }^{26} \mathrm{e}$ analisado por Teixeira (1996, p. 59): 
Uma perspectiva de transformar o distante em próximo, o estranho em familiar [...] orientada pelo desejo de diálogo com o objeto da reflexão para que ele nos fale, numa língua não necessariamente nossa, mas que seja compreensível, e nessa medida se nos torne relevante, nos enriqueça e contribua para aprofundar a auto-compreensão do nosso papel na construção da sociedade, ou, na expressão tão cara à hermenêutica, do mundo da vida.

Teixeira (1996), em sua tese de doutoramento, discutiu as contribuições da Epidemiologia para o campo do planejamento em saúde, trabalhando as dimensões do sujeito e da prática que, num contexto articulado, estabelecem o que ela denominou "invenção do futuro". Sua caminhada teve como ponto de partida a discussão histórica, identificando concepções, métodos e técnicas que, no âmbito das propostas metodológicas do planejamento em saúde desenvolvidas, possibilitassem contribuir para a redefinição das práticas para a reorientação da gestão e da organização social na saúde. Essas práticas, consideradas como sociais e históricas.

Discutiu também o lugar da Epidemiologia nas propostas metodológicas do planejamento e programação em saúde, respeitando os posicionamentos dos sujeitos, os tempos históricos e os contextos nos quais se desenvolveram os elementos epidemiológicos da planificação. E apresentou perspectivas teórico-metodológicas para a articulação entre a epidemiologia e o planejamento, partindo do princípio que as mesmas contribuiriam para o aperfeiçoamento e redefinição das práticas de planejamento e programação em saúde, conduzindo o debate à constatação da necessidade da compreensão das representações sociais do processo saúde-doença e da descoberta de novos "modos de andar a vida" (TESTA, 2004) como condicionante e determinante dessa conflituosa relação.

R. Campos (2003), ao situar o planejamento no labirinto, em sua tese de doutoramento, também busca estabelecer uma conexão entre o sujeito e a prática no campo do planejamento em saúde. Se utiliza de metáforas mitológicas para aproximar a práxis da clínica à práxis do planejamento, compreendendo que as mudanças nos serviços de saúde serão implementadas a partir da aproximação teórico-prática entre o planejamento e a clínica. Ainda que, na prática, a autora mostre a existência de certo mal-estar que submete esse esforço social de aproximação ao status de sofrimento. 
E os sujeitos, continuam percorrendo caminhos já trilhados, repetindo rituais esvaziados de sentido, fazendo consultas que não resolvem nada, planos que nunca se concretizam, vivendo conflitos institucionais que sempre se repetem... Sem barbante, sem armas, sozinhos, sem nos falar entre nós, sem conseguir escutar o outro, percorrendo a estrada que nos mandaram. (CAMPOS, R., 2003)

De fato, aproximar o planejamento da clínica ou da epidemiologia como movimentos de mudança da práxis são ações que não se esgotam e que remontam a relação entre os sujeitos e a sociedade. Se pretendermos desenvolver práticas transformadoras, atuando como sujeitos da transformação social, não podemos perder de vista as dimensões do saber ser, do saber fazer e do saber como, já discutidas amiúde nos primeiros capítulos deste livro.

A práxis e o sujeito formam uma única totalidade na história, ainda que se apresentem com singularidades e pluralidades. Os enfoques do planejamento em saúde reforçam essa ideia de totalidade, porque demonstram que a relação sujeito/práxis se revela num encontro entre as dimensões macropolítica e micropolítica da sociedade concreta. Assim, transformar a realidade, como objeto primordial do planejamento em saúde é uma ação de sujeitos livres, que atuam na dimensão da práxis com a autonomia que lhes é conferida pela sua postura pedagógica libertadora, expressando uma autoridade construída através das lutas contra-hegemônicas.

Para os autores (SANTOS, 2003; TEIXEIRA, 1996, 2003) que defendem esta perspectiva, os sujeitos do planejamento são todos aqueles que fazem parte do contexto a ser planejado. Eles se relacionam por meio de práticas educativas e de interações que extrapolam os conhecimentos do campo da saúde. Comunicam-se através de diálogos interativos, constituídos nos momentos do planejamento, que refletem a sua atitude pedagógica enquanto sujeito a serviço da libertação. De fato, mediante as outras perspectivas, pode-se afirmar que essa é a que mais se aproxima do que poderíamos chamar de "Planejamento para a Liberdade" - uma abordagem centrada no sujeito livre em ação para a transformação da realidade.

O sujeito coletivo da saúde - a sociedade - só pode se libertar do julgo e da servidão à alienação se considerar os sujeitos da práxis como 
fundantes e instituintes do seu processo de transformação. Sem essa compreensão, a luta pela vida se evadirá na direção da manutenção do status quo, afastando as possibilidades libertadoras da sua atuação pedagógica.

\section{REFERÊNCIAS}

ALBUQUERQUE, J. A. G. Instituição e poder: a análise concreta das relações de poder nas instituições. 2. ed. Rio de Janeiro: Edições Graal, 1986.

ASSIS, M. M. A. As formas de produção dos serviços de saúde: o público e o privado. 1998. 313 p. Tese (doutorado em Enfermagem) - Escola de Enfermagem, Universidade de São Paulo, Ribeirão Preto.

BOBBIO, N. Estado, governo e sociedade: para uma teoria geral da política. 12. ed. Tradução Marco Aurélio Nogueira. Rio de Janeiro: Paz e terra, 2005.

CAMPOS, G. W. S. Um método para análise e co-gestão de coletivos. São Paulo: Hucitec, 2000.

. Reforma da reforma: repensando a saúde. São Paulo: Hucitec, 1992.

; MERHY, E. E.; NUNES, E. D. Planejamento sem normas. 2. ed. São Paulo: Hucitec,1994.

CAMPOS, R. T. O. 0 planejamento no labirinto: uma viagem hermenêutica. São Paulo: Hucitec, 2003.

CASTORIADIS, C. A instituição imaginária da sociedade. Tradução de Guy Reynald. Rio de Janeiro: Paz e Terra, 1986.

FOUCAULT, M. Microfisica do poder. 18. ed. Organização, introdução e revisão técnica de Roberto Machado. Rio de Janeiro: Edições Graal, 2003.

FREIRE, P. Educação e mudança. 29. ed. Rio de Janeiro: Paz e Terra, 1979.

. Pedagogia da autonomia: saberes necessários à prática educativa. 27. ed. Rio de Janeiro: Paz e Terra, 1996.

. Pedagogia do oprimido. 32. ed. Rio de Janeiro: Paz e Terra, 1987.

; SHOR, I. Medo e ousadia: o cotidiano do professor. 10. ed. Tradução Adriana Lopes, revisão técnica Lólio Lourenço de Oliveira. Rio de Janeiro: Paz e Terra, 1986.

GADOTTI, M. Pedagogia da Práxis. 3. ed. São Paulo: Cortez, 2001.

GALLO, E. Razão e planejamento: reflexões sobre política, estratégia e liberdade. São Paulo: Abrasco, 1995.

GRAMSCI, A. Concepção dialética da história. 9. ed. Tradução de Carlos Nelson Coutinho. Rio de Janeiro: Civilização Brasileira, 1991.

HOUAISS, A. Dicionário Houaiss de língua portuguesa. Rio de Janeiro: Objetiva, 2001. 
MATUS, C. Política, planejamento e governo. São Paulo: Hucitec, 1993.

MERHY, E. E. O conhecer militante do sujeito implicado: o desafio de reconhecê-lo como saber válido. In: FRANCO, T. B. et al. (Org.). Acolher chapecó: uma experiência de mudança do modelo assistencial, com base no processo de trabalho. São Paulo: Hucitec, 2004.

MINAYO, M. C. Estrutura e sujeito, determinismo e protagonismo histórico: uma reflexão sobre a práxis da saúde coletiva. Ci. Saúde Col., Rio de Janeiro, v. 6, n. 1, p. 7-19, 2001.

MISOCZKY, M. C. O campo da Atenção à Saúde após a Constituição de 1988: uma narrativa de sua produção social. Porto Alegre: Dacasa, 2002.

SADER, E. Quando novos personagens entraram em cena: experiências e lutas dos trabalhadores da Grande São Paulo 1970-1980. 2. ed. Rio de Janeiro: Paz e Terra, 1991.

SANTOS, B. S. Introdução a uma ciência pós-moderna. 4. ed. Rio de Janeiro: Graal, 2003.

TEIXEIRA, C. F. Epidemiologia e planejamento em saúde. Ci. Saúde Col., Rio de Janeiro, v. 4, n. 2, p. 287-303, 1999.

. Epidemiologia e planejamento em saúde: contribuição ao estudo da prática epidemiológica no Brasil: 1990-1995. 1996. 273 f. Tese (Doutoramento em Saúde Pública) - Instituto de Saúde Coletiva, Universidade Federal da Bahia, Salvador.

TESTA, M. Pensar en salud. 3. ed. Buenos Aires: Lugar Editorial, 2004. torial, 1997.

Saber en salud: la construcción del conocimiento. Buenos Aires: Lugar Edi- 



\section{CAPÍTULO 7}

\section{Ponto de chegada para iniciar uma nova caminhada}

Washington Luiz Abreu de Jesus

[...] todo conhecimento é provisório. No debate e na experiência prática ganhamos novas e mais ricas interrogações, nas relações que vivenciamos uns com outros, nos espaços sociais que habitamos e trabalhamos. Essas relações que fazem a prática cotidiana são permeadas por singularidades, conflitos, verdades absolutizadas, dúvidas, diferenças, convergências que podem ser exploradas, de modo que as certezas ou incertezas se tornem instrumentos de criatividade, diálogo, debate. Implica inserir no jogo a visão acerca da mudança - e suas condições de possibilidades na realidade específica -, assim como o compromisso acerca dos sujeitos participantes que planejam, articulam e integram um futuro desejado [...]. (ASSIS, 1998)

Chegamos ao ponto do qual, verdadeiramente, deveríamos ter partido - o ponto de chegada. Lugar onde de fato podemos, inspirados em Teixeira (2003), “desatar os nós” para chegar ao pódio e comemorar uma etapa vencida, e "criar os laços" para novos momentos de caminhada, aproximação e reflexão.

Descobrimos aqui um pouco mais sobre a "verdade interior" do planejamento em saúde orientado pela hermenêutica e o deciframos outro tanto, construído historicamente, como parte da dialética. Procuramos compreender melhor suas nuances, contradições, limites e potencialidades no exercício da hermenêutico-dialética, que nos permite evidenciar que a pedagogia da Saúde Coletiva possibilita que nos constituamos enquanto sujeitos livres a serviço da libertação, apesar das investidas que possam surgir por parte dos sujeitos da alienação e do poder. Somos sujeitos da práxis e da revolução, constituídos a partir de uma concepção dialética de existência na luta em defesa de uma vida transformada, ainda que nos limites impostos pela realidade objetiva. 
Ao caminhar pelos labirintos do planejamento em saúde, apreendendo a metáfora desenvolvida por Campos (2003), percebemos que as possibilidades de intervenção sobre a realidade são diversas e se constituíram ao longo de muitos anos, tanto no cenário internacional, quanto no nacional. Os sujeitos dessa construção, ainda que se constituíssem enquanto livres, enveredaram-se na busca de novos modelos de intervenção em sua prática, inovando, transformando o que já estava dado - agregando valor de uso ao objeto do planejamento na área da saúde.

Utilizando os termos da hermenêutica clássica, podemos dizer que a luta pela vida travada pelos sujeitos do planejamento em saúde é uma luta pela "verdade", que tem o poder de libertar do julgo e da servidão da forma, elevando a técnica ao patamar de prática transformadora da realidade - uma práxis social.

Desde os primórdios da planificação em saúde na América Latina, a busca incansável dos planejadores se deu no sentido de estabelecer graus de liberdade para o setor, ainda que, no contexto, a questão econômica fosse o pano de fundo para as ações determinadas.

O jogo político aliado aos interesses do capital podem até ter "maculado" o propósito da planificação, porém não sufocaram o desejo dos planejadores por mudanças na ordem estabelecida. Podemos testificar isso, relembrando o fato de que após o "fracasso" do Método CENDES/OPS, muitos dos seus idealizadores engrossaram as fileiras daqueles que propuseram novos modelos de planejamento para a saúde, pautando-se em questões sociais e em necessidades que se estabeleciam individual e coletivamente.

Os enfoques Estratégico, Comunicativo, Analítico-institucional e Participativo, convivendo com o Enfoque Normativo dialeticamente, proporcionaram à área de planejamento em saúde o descobrimento de diversos caminhos, que no híbrido teórico-conceitual coadunam com a ideia de transformação da realidade, ainda que, em muitos momentos se busque, por força da intencionalidade de alguns sujeitos, a manutenção da ordem estabelecida através dos mecanismos da coerção e da alienação, característicos do exercício do poder em suas arenas decisórias, em constante conflito. 
A "doce descoberta" sobre os sujeitos do planejamento foi um movimento deveras instigante. A leitura e o aprofundamento da produção científica que selecionamos para este estudo nos permitiram refletir acerca do papel que desempenhamos na sociedade.

Testificar que o planejamento em saúde no Brasil, no período 19902010, foi marcado pela discussão do acesso aos serviços de saúde, nos fez compreender como é importante aproximar a teoria da prática, pois nos aproximamos de uma realidade objetiva e concreta, que de fato não é tão explorada quando se estuda esta área. 0 acesso aos serviços de saúde foi a grande novidade, pelo menos para nós, encontrada no mergulho hermenêutico-dialético que realizamos. Foi uma surpresa esperada, se é que podemos assim dizer!

Descobrir novos caminhos para se discutir o poder nas suas diversas dimensões foi uma experiência sem igual. Permitimos-nos viajar no labirinto do conhecimento e encontrar o fio de Ariadne para a transformação: a práxis.

Discutir o sujeito numa perspectiva pedagógica foi um momento de extremo reencontro - um dia de graça! Momento de autoconhecimento. De concretização de sonhos. De uma aproximação mais concreta com a quebra de paradigmas. Momento em que, verdadeiramente, o caminho que trilhamos nos possibilitou enxergar uma imagem-objetivo mais concreta - a totalidade, ainda que parcial.

Inspirados mais uma vez em Campos (2003), resgatamos a metáfora da novidade enquanto "objeto-sereia", captada a partir dos versos de Herbert Vianna: "a novidade como um sonho, um milagre tão risonho, um pesadelo tão medonho, uma guerra, um paradoxo estendido na areia [...]".

Um "sonho de liberdade", materializado na descoberta da pedagogia da libertação de Paulo Freire e na pedagogia da práxis de Moacir Gadotti.

Um "milagre risonho", que emerge da descoberta feliz de que somos sujeitos e que podemos ser livres se valorizarmos a práxis e se compreendermos que somos frutos de uma ação pedagógica que pode nos libertar da servidão e da alienação.

Um "pesadelo medonho" quando encontramos nas esquinas do caminho os sujeitos da alienação e do poder, lançando sobre nós seus dardos 
inflamados para nos silenciar, trabalhando para a manutenção da ordem estabelecida e pela hegemonização do status quo.

Uma "guerra", resultado da nossa luta pela vida em defesa dos ideais de liberdade, para a transformação social, para a transformação dos sujeitos.

Um "paradoxo estendido na areia", quando, mesmo participando dos movimentos de mudança, nos deparamos com as contradições que se estabelecem no confronto entre o que queremos e o que podemos fazer na luta pela transformação da realidade.

E a novidade não cessa de aparecer diante dos nossos olhos no mergulho hermenêutico-dialético que fizemos. Ela também se revela na testificação de que somos plurais no entendimento e concebemos o planejamento na saúde de diversas formas: uma técnica, um método, um modo, um meio, um instrumento/atividade, um subsídio, um dispositivo, uma práxis - elementos constituintes do modo de se pensar o planejamento, isto é, suas concepções.

Concepções que formam a ideologia que subsidia a constituição de estruturas e formações, lóci de operacionalização das práticas pedagógicas que constroem os sujeitos da vida re-significados pela práxis.

Práxis que constrói e reconstrói; que re-significa; que estabelece graus diferenciados de liberdade na ação; que permite ao sujeito mediar sua chegada ao ponto de partida para recomeçar - ao ponto de chegada. Espaço que é o lócus da inflexão hermenêutica do planejamento em saúde: um lugar histórico, uma realidade objetiva. Lugar onde os dilemas e conflitos se estabelecem e onde os sujeitos, interagindo entre si, permitem-se compreender e serem compreendidos, lançando mão de suas vicissitudes e se despindo de suas vaidades, na busca da "verdade-ciência", "verdade-práxis" e "verdade-vida", enquanto propósitos concretamente estabelecidos.

De fato, as incertezas, as dúvidas, os dilemas e os desafios se colocam a cada instante quando nos colocamos à prova e assumimos a identidade de sujeito epistêmico e avaliador. Não que tenhamos "medo" de enfrentar as críticas que possam surgir, mas por termos "medo" de assumir o conflito da nossa realidade de sujeito, que muitas vezes não nos possibilita 
romper abruptamente com o status quo. Mas, mesmo diante das incertezas que se apresentam nos caminhos do cotidiano, como sujeitos da vida, aceitamos o desafio de enfrentá-las, buscando graus maiores de liberdade no cenário das lutas em defesa da vida individual e coletiva, transformando-nos pedagogicamente em sujeitos da práxis a serviço da libertação.

Os sujeitos da práxis são militantes, ativistas críticos cujo esforço permanente é o do crescimento, da criação, da recriação permanente do novo, da iluminação da realidade. Seus temores e seus medos revelam seus sonhos e seus desejos. São os sinais do trabalho de transformação. Uma "visão de futuro". Uma "ponta de esperança".

A sorte está lançada! Agora, é só decidir o caminho.

\section{REFERÊNCIAS}

ASSIS, M. M. A. As formas de produção dos serviços de saúde: o público e o privado. 1998. 313 p. Tese (doutorado em Enfermagem) - Escola de Enfermagem, Universidade de São Paulo, Ribeirão Preto.

CAMPOS, R.T. O. 0 planejamento no labirinto: uma viagem hermenêutica. São Paulo: Hucitec, 2003.

TEIXEIRA, C. F. A mudança do modelo de atenção à saúde no SUS: desatando nós, criando laços. Saúde em Debate, Rio de Janeiro, v. 27, n. 65, p.257-277, 2003. 



\section{Princípios e Diretrizes do SUS: expressões de uma luta histórica do povo brasileiro ${ }^{1}$}

Washington Luiz Abreu de Jesus ${ }^{2}$

O tema que iremos abordar neste texto é "Sistema Único de Saúde: histórico, princípios e diretrizes”. Trata-se de um tema aparentemente simples, porém, considerando o processo de acumulações que ele possui, vemo-nos diante de um grande desafio - como abordar a questão sem reproduzir a retórica de textos que a apresentam de modo linear, acrítico e descontextualizado? Mesmo reconhecendo todo o processo de construção intelectual sobre a questão, e que tratar do tema não pode ser considerado "algo novo", iremos construir nosso pensamento tomando a "história" como um elemento central, cujo processo desencadeia e é desencadeado no contexto das relações que permeiam a construção de uma sociedade.

Ora, se o Sistema de Saúde brasileiro atual é fruto de uma disputa conjuntural da sociedade no enfrentamento de seus problemas concretos, sendo, portanto, um processo de construção social do qual derivam seus princípios e diretrizes, há que se adotar um raciocínio analítico que permita discorrer sobre como esse processo efetivamente se deu ao longo da história do país.

Como a história é nosso elemento central, recorremos a ela para apresentar uma "gênese" dessa demanda e assim compreender um pouco do que poderia justificar os movimentos de luta que se conformam para

1 Este texto é fruto das minhas reflexões acerca da conformação histórica do Sistema Único de Saúde no Brasil. Originalmente foi construído quando me apresentava ao concurso para professor assistente de Medicina Preventiva e Social da Faculdade de Medicina da Universidade Federal da Bahia (aprovado). É um exercício de "livre pensar", não sendo, neste momento, minha preocupação indicar as referências utilizadas ou atualizar o debate em virtude da regulamentação da Lei Orgânica da Saúde, o que farei oportunamente quando resolver publicá-lo em forma de artigo científico ou texto didático.

2 Brasileiro, médico, sanitarista e militante do SUS. 
construir, no seio da sociedade brasileira, um debate acerca de qual sistema de saúde seria mais adequado à realidade social.

Por outro lado, a "expressão" histórica da demanda por um sistema público de saúde universal, igualitário e equânime é uma resposta construída socialmente a uma conjuntura que se constitui a partir do enfrentamento da realidade concreta do país e expõe a existência de uma superestrutura social e econômica contraditória aos princípios e diretrizes do sistema proposto, o que ratifica a necessidade da luta pela sua efetiva construção nos âmbitos político, técnico, gerencial e operativo, e junto à sociedade civil.

Se o Sistema Único de Saúde - SUS, então, resulta de uma construção histórico-social, ele é também fruto dos dilemas desse processo. Antes disso, é fruto dos desejos e pulsões que mobilizaram a sociedade nessa direção. E aí está a construção do nosso pensamento neste texto: discutir a "gênese" [possível] do que identificamos hoje como princípios e diretrizes do SUS, reconhecendo-os como produtos de um processo histórico - "expressões".

\section{O PROCESSO HISTÓRICO DE CONSTRUÇÃO DO SISTEMA PÚBLICO DE SAÚDE NO BRASIL: UMA GÊNESE PARA O SUS?}

A saúde da população brasileira, durante muito tempo negligenciada pelos governantes, somente possui intervenções organizadas numa perspectiva pública no final do Século XIX, por meio do Sanitarismo Campanhista. Ainda assim, com o viés higienista que, a despeito das intervenções coletivas, tinha como retaguarda a superestrutura econômica da época, agro-exportadora. A assistência médica era essencialmente liberal.

Daí por diante, considerando o perfil de país liderado, periférico, o papel do Estado junto ao setor saúde vem sendo construído sempre por demanda: para responder às pressões do operariado diante de suas necessidades de assistência médica, pensões e aposentadorias (CAPS e IAPS); para responder às pressões da classe dominante e da superestrutura eclesiástica na relação com o próprio Estado na mediação sobre os conflitos sociais do país expressos nas condições de saúde das pessoas (filantropia); 
para responder às pressões do capital estrangeiro da saúde diante da necessidade de desenvolvimento no setor (complexo médico - industrial); para responder aos interesses classistas e elitistas das profissões liberais (modelo médico - assistencial privatista).

Um sistema público de saúde nessa conjuntura se revela ineficaz na medida em que efetivamente ele não se constitui como tal [público]. 0 que está na ordem dos acontecimentos é exatamente a construção anacrônica da resposta social para dar conta de responder às necessidades expressas no âmbito da saúde dos indivíduos, da coletividade e dos ambientes.

Para agravar ainda mais a questão, historicamente o Brasil adotou a postura passiva de "consumir" o conhecimento estrangeiro e foi construindo sua "mão de obra" em saúde sem considerar as reais necessidades do país. Ou seja, não se produziu capital intelectual próprio no sentido de termos, ao longo da história de construção do sistema de saúde, à força de submeter sua lógica conjuntural às necessidades concretas da população.

É óbvio que é preciso reconhecer que a afirmação acima não é absoluta na essência. As reflexões críticas sobre o processo de constituição da sociedade brasileira vêm acompanhando o desenvolvimento histórico do país desde os séculos XVIII e XIX, tendo o século XX como marco de inflexão importante.

Voltando à questão do sistema público de saúde, o que historicamente vimos foi uma fragmentação estrutural, permeada pela inexistência de uma política pública que efetivamente respondesse aos problemas concretos da sociedade no tocante ao setor. E aí está a gênese histórica dos movimentos de luta em busca da saúde desenvolvidos pela população brasileira, em resposta, inclusive, às ações dos próprios governantes sobre a questão.

Para além de compreender as Caixas de Aposentadorias e Pensões (CAPS) e os Institutos de Aposentadorias e Pensões (IAPS) como concessões governamentais, é preciso compreendê-los como resultado de processos históricos de enfrentamento social, e que, na gênese histórica de um sistema público fragmentado, expressa a luta dos trabalhadores pelo direito de trabalhar com saúde e poder desfrutar disso com os seus filhos, com sua família. 
Ainda nessa perspectiva, a organização da Saúde Pública como resposta social produz, ao longo da história recente do país, reflexões fundamentais acerca dos modos de ação do Estado sobre as necessidades expressas da população em relação ao setor de saúde. E isso vai produzir, ao longo dessa mesma história, a constituição de vários arranjos gerenciais evidenciados exatamente no modo como foi sendo construída a intervenção estatal da Saúde Pública no Brasil - do Sanitarismo Campanhista ao desenvolvimentista, à concepção de Vigilância em Saúde Pública, à concepção ampliada de Saúde expressa na Constituição Federal de 1988.

Destarte, as pressões da conjuntura internacional para garantir a expansão do capitalismo enquanto modelo econômico hegemônico contribuem e determinam certa ausência na ação sobre a realidade concreta das necessidades de saúde. Na lógica proposta, o papel do Estado seria efetivamente abrir as portas à iniciativa privada, ou melhor, ao desejo privado. $\mathrm{E}$ aí está revelado o primeiro grande dilema estrutural da conjuntura social brasileira: da colônia à república democrática, da escravidão ao trabalhismo, o Brasil percorre sua história buscando o crescimento econômico de todo modo, mas deseja que o Estado seja o "sustentador" desse desenvolvimento. Liberdade e controle na ordem dos fatos; o Brasil oscila entre o desejo de ser potência econômica e o dilema de ter que enfrentar os interesses privados para garantir à sua população mais dignidade.

E o SUS nisso?

A reflexão é: se os sistemas de saúde são respostas sociais, há que se reconhecer que o caso do SUS é emblemático. O que a sociedade brasileira dispunha era um sistema de saúde fragmentado, dicotômico, desfinanciado, desqualificado do ponto de vista de dar respostas efetivas às necessidades sociais.

As lutas históricas pela garantia do direito à saúde se expressam nas vitórias que historicamente os brasileiros vão alcançando. Ainda que as conjunturas temporais tenham produzido rupturas históricas importantes nesses processos de luta, efetivamente foi sendo construído o ambiente para que o SUS se tornasse uma realidade histórica, ainda que parcial do ponto de vista de sua concretização. 
Quando a sociedade brasileira inicia seu processo de reflexões críticas sobre suas necessidades de saúde, ela toma o sistema público como um objeto de análise e disputa.

Refletir sobre isto significa, antes de tudo, resgatar a história e, debruçando-se sobre ela, problematizar. Então, a questão do momento era construir socialmente uma reflexão sobre a problemática da saúde e lançar as bases para o que viria a ser o processo de reforma Sanitária Brasileira um processo muito longo.

A problematização se inicia com as reflexões sobre o modelo de formação médica nos espaços acadêmicos - uma denúncia de falência do modelo centrado nos procedimentos, mas também acontece no seio da própria sociedade, que passa a questionar as respostas do Estado às suas necessidades de saúde e reivindica uma recomposição de forças para o enfrentamento desta questão.

Outra face dessa "gênese" histórica é exatamente discutir como o pensamento crítico produz reflexões sobre a realidade que permitem esclarecer a "problemática" da saúde da população brasileira.

Se for uma construção social, está posto que reconhecer a problemática é enfrentar os problemas de modo corajoso, colocando-a na "ordem da história”. As constatações estavam apresentadas: a) o sistema de saúde era fragmentado, excludente e discriminatório; b) a população brasileira não tinha acesso igual às ações e aos serviços de saúde, e estes, quando existiam, restringiam-se a algumas regiões e cidades; c) o poder decisório sobre as intervenções era centralizado, burocrático e pautado pelo clientelismo autoritário; d) a cidadania, regulada, não se expressava para decidir os desígnios da construção das intervenções governamentais sobre a saúde.

Constatações à mesa, é hora da construção do processo de discussão sobre elas. Aí toma corpo e ganha vida a partir da ação de sujeitos sociais (individuais e coletivos), que, se aproveitando da conjuntura, ou melhor, da disputa conjuntural travada nas décadas de 1970 e 1980, constroem e concretizam o Movimento pela Reforma Sanitária Brasileira, que tem como "expressão" concreta o SUS Constitucional.

Os movimentos sociais, os intelectuais e a própria sociedade, por meio do Movimento Popular de Saúde (MOPS), o Movimento Estudantil, 
os Departamentos de Medicina Preventiva e Social, o Centro Brasileiro de Estudos em Saúde (CEBES), a Associação Brasileira de Pós-Graduação em Saúde Coletiva (ABRASCO), o Movimento pela Renovação da Medicina, os sindicatos e tantos outros sujeitos se aliam na discussão acerca da solução dos problemas estruturais do setor de saúde no Brasil - criam-se várias agendas (social, política, técnica) para conjecturar uma proposta concreta de Sistema de Saúde, o SUS.

Sem querer encerrar o olhar sobre a questão, aí está posta a reflexão sobre essa "gênese" histórica. É no reconhecimento dos problemas estruturais do sistema de saúde que se dá a construção social do que hoje temos como "princípios" e “diretrizes” do Sistema Único de Saúde brasileiro. As disputas travadas na arena do movimento pela redemocratização do país permitiram àqueles que, participando do processo, tornaram-se sujeitos sociais históricos, pautar o modelo de cidadania que era mais coerente ao processo de constituição histórica da sociedade brasileira. De cidadania regulada à cidadania plena, estava na pauta a superação de um modelo assistencialista, fragmentado e pautado no seguro social, e a instalação de um modelo pautado na seguridade social, capaz de recuperar a dignidade da sociedade brasileira, ainda que muitos dilemas ainda tenham permanecido.

\section{PRINCÍPIOS E DIRETRIZES DO SUS: EXPRESSÕES DE UMA CONSTRUÇÃO HISTÓRICO-SOCIAL?}

Pretendemos agora, apoiados ainda na perspectiva crítica da história, refletir sobre a conformação dos princípios e diretrizes do SUS, delineando algumas reflexões acerca de suas bases. É num momento retumbante de discussões acerca dos problemas estruturais da saúde no Brasil que, apoiados pelos ideais democráticos, constroem-se o debate e as disputas para conceituar o SUS. Responder a esses problemas é, antes de tudo, pensar sobre eles de modo concreto e transformá-los:

a) para enfrentar as questões relativas à falta de acesso de todas as políticas públicas de saúde, resolveu-se adotar o princípio da universalidade que, para além de garantir acesso, deve garanti-lo de modo qualificado e resolutivo a todos os cidadãos brasileiros; 
b) para enfrentar a questão da exclusão, da discriminação, das desigualdades (sociais, étnicas, de gênero, territoriais e econômicas), adotou-se o princípio da equidade, que tem a igualdade como principal forma de expressão. É preciso ter um sistema público de saúde que, na sua essência, garanta que aqueles que mais precisam sejam efetivamente assistidos, mas que também isso ocorra com a devida justiça social, já que todos são iguais perante a lei. Ademais, pensar em equidade e justiça social remonta a discussões sobre a responsabilidade pública da ação governamental na correta distribuição de recursos em saúde, sejam eles financeiros (alocação), humanos (lotação), físicos (distribuição/suficiência), etc.

c) para responder ao problema da centralização decisória e burocrática, idealizou-se o princípio/diretriz da descentralização [assim expresso por constar da lei orgânica da saúde no rol comum dos princípios e diretrizes]. Essa descentralização, de caráter político-administrativo, expressa exatamente o desejo de superação da prática autoritária e clientelista da decisão sobre os desígnios do setor. Com ela tornam-se necessárias as constituições de estâncias colegiadas de gestão entre os gestores já que, na essência, a direção do SUS é única. Temos aí, portanto, as bases para constituir as Comissões Intergestoras Bipartite e Tripartite (CIB e CIT), marcos da descentralização político-administrativa, que passam a incluir no rol dos decisores o Ministério da Saúde e as Secretarias de Saúde estaduais e municipais.

d) para enfrentar a questão da fragmentação do cuidado e da dicotomia do sistema de saúde, constrói-se o princípio da integralidade. A questão da universalização dos princípios da dignidade humana está perdida no momento em que, por forças de uma tensão histórica, sobressai o cuidado fragmentado às ações de saúde dos profissionais sobre o indivíduo, as coletividades e o ambiente, e também fragmentando a ação do Estado, cujo trabalho não produz mudanças no estado de saúde das pessoas. A disputa posta aí, para além de uma disputa legal e organizacional, é paradigmática: "o ser humano é um todo na sua essência e o cuidado deve refletir essa ideia”. Daí a necessidade de integralidade.

e) para superar a concepção de cidadania regulada e do autoritarismo, expressas na ausência da participação social nos processos de decisão 
sobre os desígnios do setor de saúde, constrói-se o princípio da participação da comunidade, que oportunamente se institui, já que o período de nascimento do SUS é o período da redemocratização do país, e coerentemente com o movimento da Reforma Sanitária Brasileira, trazer este princípio à "ordem da história" é afirmar a potência desse processo. Daí a constituição, na Lei Orgânica da Saúde, dos Conselhos de Saúde e Conferências de Saúde como legítimos espaços de participação social.

Enfrentar essas questões principais requer a construção de outros desígnios. Construir um sistema público de saúde universal, igualitário, equânime, justo, pautado na integralidade, descentralizado e que tenha a efetiva participação da sociedade requer um investimento organizacional. Daí os princípios da regionalização e hierarquização, que para além de apontar os arranjos necessários a garantir a resolubilidade do sistema, também indicam a necessária organização solidária que deve existir entre os decisores, para que todos os cidadãos sejam atendidos nas suas necessidades de saúde. E aí também está revelado o outro sentido da participação, quando se faz necessário superar as barreiras e os limites interfederativos, promovendo a discussão acerca da conformação de sistemas regionalizados de saúde e redes de atenção à saúde, de modo a garantir integralidade. O Estado tem papel importante na intermediação dos processos de regionalização e hierarquização do sistema - por isso é diretriz fundamental.

Outros princípios e diretrizes acabam por surgir no percurso: garantia à informação, direito de escolher (autonomia), vigilância da saúde como eixo orientador da ação, controle público das ações essenciais à manutenção da vida, etc. Refletindo a intensa construção da luta dos diversos atores sociais na construção da demanda pelo SUS, enquanto sistema público de saúde. Porém, o processo de disputa ainda está inacabado. É preciso continuar militando para que de fato esses princípios e essas diretrizes se concretizem na prática. A Reforma Sanitária Brasileira ainda não está completa e novos atores precisam erguer as bandeiras de luta para somar-se àquelas que historicamente disputaram e conquistara este SUS real que temos. 


\section{A TÍTULO DE CONCLUSÃO (AINDA QUE DE MODO PRELIMINAR)}

O SUS é fruto de uma construção social e histórica marcada pelas disputas na direção de garantir que todos os brasileiros tenham direito à saúde, na perspectiva ampliada, com interface sobre todas as dimensões de suas vidas.

Optamos por trabalhar este texto a partir de reflexões históricas para construir as diretrizes que norteiam e expressam a totalidade do SUS Constitucional.

Para concluir, ainda que provisoriamente, faremos um breve resumo dos principais fatos históricos que culminaram na construção do SUS, para deixar claro que o caminho adotado é mais um olhar de reconhecimento à história oficial.

- Na década de 1970 toma corpo o Movimento Sanitário Brasileiro que, em meio à crise do sistema de saúde, lança as bases do que se denominou Reforma Sanitária Brasileira.

- Na década de 1980 a crise se agrava, o país entra em recessão econômica e o processo de redemocratização do país ganha força, com o "povo" nas ruas. É criado o Sistema Unificado e Descentralizado de Saúde (SUDS), como reflexo da profunda modificação da relação entre o Estado e as prestadoras de serviços, iniciando-se efetivamente a construção de um sistema. Realiza-se a $8^{\text {a }}$ Conferência Nacional de Saúde, em 1986, que lança as bases para a construção do SUS, e vai, por meio de representantes legítimos como Sérgio Arouca, Eleutério Rodrigues Neto, Hésio Cordeiro [e tantos outros], ganhar força junto à Assembleia Nacional Constituinte, para garantir que suas proposições sejam incorporadas ao texto constitucional.

- Em 1988, promulgada a Constituição Cidadã, tem-se consolidado do ponto de vista legal o SUS, seus princípios, diretrizes e suas regras básicas de financiamento, no contexto da Seguridade Social e garantido pelo Orçamento da Seguridade Social.

- Em 1990, com a regulamentação do SUS, por meio da Lei Orgânica da Saúde [Leis nº. 8080 e 8142/90], reafirmam-se os princípios e as 
diretrizes do sistema, definindo-se as bases concretas do seu funcionamento e instituindo-se uma nova fase no processo histórico de construção do sistema público de saúde brasileiro.

Se um sistema de saúde é de fato uma resposta social, aí está a resposta social do Brasil a essa demanda. Cabe àqueles que nele militam continuar reconstruindo cotidianamente a história e redefinindo as expressões concretas desse sistema no âmago da sociedade brasileira. Um SUS efetivamente universal, equânime, igualitário, pautado na integralidade, que se construa com base no respeito ao direito de cidadania, responsabilidade mútua, tenha um caráter organizativo, inclusivo e abrangente, que chegue a todos os "cantos" do país e se organize para prestar o cuidado de modo racional e justo.

Salvador, 26 de março de 2011 


\section{Sistematização da produção bibliográfica de referência (Base de dados SciELO/1990-2010)}

a) Os principais periódicos de publicação dos artigos selecionados identificados na base de dados do estudo que deu origem a este livro foram: Cadernos de Saúde Pública; Ciência e Saúde Coletiva; Revista Latino-Americana de Enfermagem; Revista de Saúde Pública; Revista Brasileira de Epidemiologia; Revista Texto e Contexto Enfermagem; Revista Saúde e Sociedade; Revista Interface; Revista de Administração Pública e ACTA Paulista de Enfermagem. Sendo que os Cadernos de Saúde Pública e a Revista Ciência e Saúde Coletiva foram identificados como os responsáveis pela maior parte das publicações sobre o tema planejamento em saúde na área de Saúde Coletiva. O detalhamento quantitativo nesta base de dados dos referidos periódicos encontra-se no quadro que se segue (Quadro 01).

QUADRO 01: Número de artigos por periódico da área de Saúde Coletiva cadastrado no SCIELO (1990-2010)

\begin{tabular}{|c|c|c|}
\hline PERIÓDICO & NÚMERO DE ARTIGOS & Percentual relativo \\
\hline Cadernos de Saúde Pública & 24 & $48,9 \%$ \\
\hline Ciência e Saúde Coletiva & 11 & $22,4 \%$ \\
Revista Latino-Americana de Enfermagem & 05 & $10,2 \%$ \\
\hline Revista de Saúde Pública & 03 & $6,1 \%$ \\
Revista Brasileira de Epidemiologia & 01 & $2,0 \%$ \\
\hline
\end{tabular}




\begin{tabular}{|c|c|c|}
\hline & & \\
Texto e Contexto Enfermagem & 01 & $2,0 \%$ \\
Revista Saúde e Sociedade & 01 & $2,0 \%$ \\
Revista Interface & 01 & $2,0 \%$ \\
Revista de Administração & 01 & $2,0 \%$ \\
Pública & & \\
ACTA Paulista de Enfermagem & 01 & $2,0 \%$ \\
\hline
\end{tabular}

b) A análise do tipo de estudo apresentado nos artigos selecionados apontou como resultados: Ensaios Teóricos ${ }^{1}$; Estudos de Avaliação de Serviços de Saúde ${ }^{2}$; Estudos de Intervenção ${ }^{3}$; Pesquisas Documentais ${ }^{4}$; Estudos de Caso $^{5}$ e Relatos de Experiência ${ }^{6}$, explicitados no quadro que se segue (Quadro 02).

1 Definimos Ensaio Teórico como um estudo que não apresenta pesquisa de campo como etapa metodológica, desenvolve-se a partir de considerações teóricas de um autor sobre determinado objeto, tomando como base outros trabalhos científicos. "Os ensaios teóricos não contêm informações baseadas em dados empíricos.” (HOPPEN, 1998)

2 Estudos de avaliação de serviços de saúde são estudos que adotam um modelo teórico de avaliação considerado padrão para analisar a estrutura, os processos e os resultados. Conforme explicitado por Vieira-da-Silva (2005), um estudo de avaliação tem o propósito de fazer julgamentos sobre programas e/ou subsidiar o processo de tomada de decisões sobre futuras programações.

3 Estudos de intervenção são aqueles cujo objetivo principal é interferir na realidade estudada para modificá-la. (TOBAR; YALOUR, 2001)

4 Pesquisas documentais são aquelas que se realizam com base em documentos guardados em órgãos públicos ou privados de qualquer natureza. (TOBAR; YALOUR 2001)

5 Estudos de caso constituem-se em desenhos privilegiados para os estudos de gestão, sendo circunscritos a poucas unidades de análise: pessoas, famílias, produtos, instituições, comunidades, regiões e países. (TOBAR; YALOUR 2001)

6 Relato de experiência é uma metodologia de observação sistemática da realidade, sem o objetivo de testar a hipótese, mas estabelecendo relações entre os achados dessa realidade e bases teóricas pertinentes, fornecendo informações importantes para o desenvolvimento de outros tipos mais elaborados de pesquisa. (DYNIEWICZ; RIVERO GUTIÉRREZ, 2005) 
QUADRO 02: Número de artigos por tipo de estudo dos periódicos selecionados da área de Saúde Coletiva (1990-2010)

\begin{tabular}{|ccc|}
\hline TIPO DE ESTUDO & NÚMERO DE ARTIGOS & Percentual relativo \\
\hline Ensaio Teórico & 20 & $40,8 \%$ \\
Estudo de Avaliação de Serviços de Saúde & 10 & $20,4 \%$ \\
Estudo de Intervenção & 06 & $12,24 \%$ \\
Estudo de Caso & 05 & $10,2 \%$ \\
Pesquisa Documental & 05 & $10,2 \%$ \\
\hline Relato de Experiência & 03 & $6,1 \%$ \\
\hline
\end{tabular}

c) Foram identificados como principais autores referenciados nos artigos selecionados: Carlos Matus; Francisco Javier Uribe Rivera; Mário Testa; Gastão Wagner de Souza Campos; Luís Carlos Oliveira Cecílio; Emerson Elias Merhy; Eugênio Vilaça Mendes; Carmen Fontes Teixeira; Jairnilson Silva Paim; Marilene de Castilho Sá; Lilia Blima Schraiber; Rosana Onocko Campos e Elizabeth Artmann. Todos esses autores foram referenciados, cabendo aos demais autores considerados o mínimo de três referências, conforme explicitado no quadro que se segue (Quadro 03).

QUADRO 03: Autores mais citados nos artigos selecionados dos periódicos da área de Saúde Coletiva (1990-2010)

\begin{tabular}{|c|c|c|c|}
\hline & Autor referenciado & $\begin{array}{c}\text { Número de } \\
\text { citações / artigos }\end{array}$ & Percentual relativo \\
\hline A & MATUS, C. & 23 & $46,9 \%$ \\
\hline B & RIVERA, F. J. U. & 20 & $40,8 \%$ \\
\hline C & TESTA, M. & 15 & $30,6 \%$ \\
\hline D & CAMPOS, G. W. S. & 14 & $28,5 \%$ \\
\hline E & CECILIO, L. C.O. & 13 & $26,5 \%$ \\
\hline F & MERHY, E. E. & 11 & $22,4 \%$ \\
\hline G & MENDES, E. V. & 10 & $20,4 \%$ \\
\hline H & TEIXEIRA, C. F. & 09 & $18,3 \%$ \\
\hline
\end{tabular}




\begin{tabular}{|c|c|c|c|}
\hline & Autor referenciado & $\begin{array}{c}\text { Número de } \\
\text { citações / artigos }\end{array}$ & Percentual relativo \\
\hline I & PAIM, J.S & 09 & $18,3 \%$ \\
J & SÁ, M.C & 09 & $18,3 \%$ \\
k & SCHRAIBER, L. & 08 & $16,3 \%$ \\
L & CAMPOS, R.O & 05 & $10,2 \%$ \\
M & ARTMANN, E. & 04 & $8,1 \%$ \\
\hline n & Outros autores considerados & \\
\hline
\end{tabular}

d) As principais instituições envolvidas na produção dos artigos selecionados foram a Escola Nacional de Saúde Pública; a Universidade de São Paulo; a Universidade Estadual de Campinas; Universidade Federal da Bahia; Universidade Estadual de Campinas, cabendo a outras universidades números menores de publicação, conforme explicitado no Quadro 04.

A produção científica da área de Planejamento no campo da Saúde Coletiva, divulgada em periódicos disponíveis na base de dados do SCIELO, apresenta, principalmente, como referências teóricas: Carlos Matus, Francisco Javier Uribe Rivera, Mário Testa, Gastão Wagner de Souza Campos e Luís Carlos Oliveira Cecílio, tomando como ponto de consideração a referência em mais de $25 \%$ dos artigos selecionados. As instituições mais expressivas na produção para esta área são a ENSP, a USP, a UFBA, e a UNICAMP, produzindo, principalmente, ensaios teóricos, estudos de avaliação de serviços de saúde e estudos de intervenção, divulgados, a priori, nas revistas Cadernos de Saúde Pública, Ciência e Saúde Coletiva e Revista Latino-Americana de Enfermagem. Organizações não acadêmicas também são responsáveis por grande parte da produção científica verificada nessa base de dados, o que demonstra o envolvimento dos sujeitos da prática no processo de planejamento desenvolvido no âmbito do Sistema Único de Saúde.

7 AYRES, I. B. S. J; LIMA, S. M.L; MINTZBERG, H; BARTOLI, A.; BOURDIEU, P.; CASTORIADIS, C.; FOUCAULT, M.; HABERMAS, J.; BARRENECHEA, J. J.; CHORNY, A. 
QUADRO 04: Artigos publicados e cadastrados na base de dados SCIELO X Instituições de Ensino e Pesquisa X Pesquisadores envolvidos

(1990-2010)

\begin{tabular}{|c|c|c|}
\hline INSTITUIÇÕES & $\begin{array}{l}\text { NÚMERO } \\
\text { DE } \\
\text { ARTIGOS }\end{array}$ & PESQUISADORES ENVOLVIDOS \\
\hline $\begin{array}{l}\text { Escola Nacional de } \\
\text { Saúde Pública (ENSP) }\end{array}$ & 13 & $\begin{array}{l}\text { GIOVANELLA, L.; VERAS, C. M. T.; } \\
\text { MARTINS, M. S.; RIVERA, F. J. U.; } \\
\text { ARTMANN, E.; AZEVEDO, C. S. A.; } \\
\text { SÁ, M. C. LIMA, J. C.; RIBEIRO, J. M.; } \\
\text { GRABOIS, V.; }\end{array}$ \\
\hline Universidade São Paulo (USP) & 09 & $\begin{array}{l}\text { UNGLERT, C. V. S.; MATSUDA, L. M.; } \\
\text { ÉVORA, Y. D. M.; GONZALEZ, R. I. } \\
\text { C.; LALUNA, M. C. M. C.; FERRAZ, C. } \\
\text { A.; MISHIMA, S. M.; PEREIRA, M. J. } \\
\text { B.; GOMES, E. L. R.; SCHRAIBER, L. B; } \\
\text { PEDUZZI, M; SALA, A.; NEMES, M. I } \\
\text { B.; CASTANHERA, E. R. L.; KON, R.; } \\
\text { MELLEIRO, M. M.; TRONCHIN, D. M. R. } \\
\text { CIAMPONE, M. H. T.; TRINDADE, E.; }\end{array}$ \\
\hline Universidade Federal da Bahia (UFBA) & 06 & $\begin{array}{l}\text { MELLO, R. R.; MOREIRA, M. E. L. } \\
\text { PAIM, J. S.; TEIXEIRA, C. F.; LOTUFO, M. } \\
\text { MIRANDA, A. S.; }\end{array}$ \\
\hline $\begin{array}{l}\text { Universidade Estadual } \\
\text { de Campinas (UNICAMP) }\end{array}$ & 05 & $\begin{array}{l}\text { CECÍLIO, L. C. O.; } \\
\text { ONOCKO CAMPOS, R. T.; }\end{array}$ \\
\hline $\begin{array}{l}\text { Universidade Estadual do Rio de Janeiro } \\
\text { (UERJ) }\end{array}$ & 04 & $\begin{array}{l}\text { VERAS, R.; MATTOS, R.; FAVERET, A. C.; } \\
\text { GRABOIS, V. }\end{array}$ \\
\hline $\begin{array}{l}\text { Universidade Federal do Rio de Janeiro } \\
\text { (UFRJ) }\end{array}$ & 03 & CAMPOS, C. E. A.; ALMEIDA, R. M. N. \\
\hline $\begin{array}{l}\text { Universidade Estadual de } \\
\text { Feira de Santana (UEFS) }\end{array}$ & 03 & $\begin{array}{l}\text { ASSIS, M. M. A.; VILASBÖAS, A. L. Q.; } \\
\text { JESUS, W. L. A }\end{array}$ \\
\hline
\end{tabular}




\begin{tabular}{|c|c|c|}
\hline INSTITUIÇÕES & $\begin{array}{l}\text { NÚMERO } \\
\text { DE } \\
\text { ARTIGOS }\end{array}$ & PESQUISADORES ENVOLVIDOS \\
\hline $\begin{array}{l}\text { Fundação Osvaldo Cruz } \\
\text { (Instituto Fernandes Figueira) }\end{array}$ & 02 & $\begin{array}{l}\text { HOROVITZ, D. D. G. ; } \\
\text { LLARENA JR, J. C.; MÉIO, M. D. B. B.; } \\
\text { MAGLUTA, C.; }\end{array}$ \\
\hline $\begin{array}{l}\text { Universidade Federal } \\
\text { do Piauí (UFPI) }\end{array}$ & 02 & PEDROSA, J. I. S. \\
\hline $\begin{array}{l}\text { Universidade Federal } \\
\text { de Santa Catarina (UFSC) }\end{array}$ & 02 & $\begin{array}{l}\text { LACERDA, J. T.; CALVO, M. C. M.; } \\
\text { FREITAS, S. F. T.; GELBCKE, F.; MATOS, } \\
\text { E.; SCHMIDT, I. S.; MESQUITA, M. P. L.; } \\
\text { PADILHA, M. F. C. }\end{array}$ \\
\hline $\begin{array}{l}\text { Universidade Estadual } \\
\text { de Maringá (UEM-PR) }\end{array}$ & 01 & SCOCHI, M. J. \\
\hline $\begin{array}{l}\text { Universidade Estadual } \\
\text { de Londrina (UEL-PR) }\end{array}$ & 01 & COSTA, N. R. \\
\hline $\begin{array}{l}\text { Universidade Federal } \\
\text { de Minas Gerais (UFMG) }\end{array}$ & 01 & LANA, F. C. F. \\
\hline $\begin{array}{l}\text { Faculdade de Ciências } \\
\text { Econômicas e da Empresa, } \\
\text { Universidade Lusíada, Porto, } \\
\text { Portugal }\end{array}$ & 01 & PINHO, M. M. \\
\hline $\begin{array}{l}\text { Centro Universitário de Volta Redonda- } \\
\text { Rio de Janeiro. (UNIFOA) }\end{array}$ & 01 & NEVES, L.A \\
\hline $\begin{array}{l}\text { Universidade Federal } \\
\text { do Mato Grosso do Sul (UFMG) }\end{array}$ & 01 & LOTUFO, M. \\
\hline $\begin{array}{l}\text { Outras instituições } \\
\text { não classificadas } \\
\text { como de ensino ou pesquisa }\end{array}$ & 14 & $\begin{array}{l}\text { REZENDE, F. A. V. S.; BOAN, F. S.; } \\
\text { NICOLETO, S. C. S.; PIOVESAN, M. F.; } \\
\text { PADRÃO, M. V. V.; DUMONT, M. U.; } \\
\text { LIMA, L. F. M.; GONDIM, G.M.; } \\
\text { FLORES, O.; NEVES L.A; SANTOS, } \\
\text { F. P.; FILHO, E. T. S.; GOMES, Z. M } \\
\text { S.; PARAHYBA, M. I.; VIEIRA, F. S.; } \\
\text { GONZÁLEZ, M. M. L.; FAVERET, A. C }\end{array}$ \\
\hline
\end{tabular}

\section{REFERÊNCIAS}

DYNIEWICZ, A. M.; RIVERO DE GUTIERREZ, M. G. Metodologia da pesquisa para enfermeiras de um hospital universitário. Rev. Latino-Am. Enfermagem, Ribeirão Preto, v. 13, n. 3, jun. 2005. 
HOPPEN, N. Sistemas de informação no Brasil: uma análise dos artigos científicos dos anos 90. Revista de Administração Contemporânea, Curitiba - PR, v. 2, n. 3, set / dez, 1998.

TOBAR, F; YALOUR, M. R. Como fazer teses em saúde pública: conselhos e idéias para formular projetos, redigir teses e informes de pesquisas. Tradução de Maria Ângela Cançado. Rio de Janeiro: Fiocruz, 2001.

VIEIRA-DA-SILVA, L. M. Conceitos, abordagens e estratégias para avaliação em saúde. In: HARTZ, Z. M. A.; VIEIRA-DA-SILVA, L. M. Avaliação em saúde: dos modelos teóricos à prática na avaliação de programas e sistemas de saúde. Salvador: Edufba; Rio de Janeiro: Fiocruz, 2005. p. 15-40. 



\section{Organizadores e autores}

Washington Luiz Abreu de Jesus - Médico, mestre em Saúde Coletiva pela Universidade Estadual de Feira de Santana/Bahia (UEFS) e doutorando em Saúde Pública pelo Instituto de Saúde Coletiva (ISC/UFBA). Professor de Medicina Preventiva e Social da Universidade Federal da Bahia (UFBA) e Coordenador de Projetos Especiais da Secretaria da Saúde do Estado da Bahia (COPE/SESAB). É professor convidado do Mestrado Profissional em Saúde Coletiva na UEFS, tendo também atuado como professor de Medicina Preventiva e Social de agosto de 2009 a julho de 2011 nesta universidade. É pesquisador na área de concentração de Políticas, Planejamento e Gestão, inserido no Núcleo de Pesquisa Integrada em Saúde Coletiva (NUPISC/UEFS). Também é professor da Pós-graduação em Saúde Pública da Faculdade Adventista da Bahia. Possui experiência no âmbito assistencial, atuando na Atenção Primária e Gestão de Sistemas e Serviços de Saúde. Com dez anos de experiência na gestão do SUS, tem atuado nos âmbitos municipal e estadual, sempre em cargos diretivos. Recebeu prêmios e menções honrosas pelos trabalhos desenvolvidos, publicados em periódicos importantes no campo da Saúde Coletiva nos últimos cinco anos.

Marluce Maria Araújo Assis - Enfermeira, Mestre em Enfermagem de Saúde Pública e Doutora em Enfermagem pela Escola de Enfermagem de Ribeirão Preto da USP (1999). Líder do Núcleo de Pesquisa Integrada em Saúde Coletiva (NUPISC/UEFS). Atualmente é professora titular da Universidade Estadual de Feira de Santana e Pró-Reitora de Pesquisa e Pós-Graduação. Atua na área de Saúde Coletiva e de Enfermagem nos seguintes temas: Planejamento e gestão em saúde, avaliação de serviços de saúde, políticas de saúde, atenção básica à saúde, programa Saúde da Família, produção do cuidado e práticas de saúde. Pesquisadora nível 2 do CNPq. Publicou vários artigos em revistas nacionais e internacionais e 04 livros, sendo um publicado pela Edufba, em 2010: Produção do cuidado no programa Saúde da Família: olhares analisadores em diferentes cenários. 
Chaider Gonçalves Andrade - Enfermeiro, especialista em Planejamento em Saúde pelo Instituto de Saúde Coletiva (ISC/UFBA). É pesquisador discente na área de concentração de Políticas, Planejamento e Gestão, do Mestrado Profissional em Saúde Coletiva da Universidade Estadual de Feira de Santana - UEFS, inserido no Núcleo de Pesquisa Integrada em Saúde Coletiva (NUPISC/UEFS). É assessor técnico da Coordenação de Projetos Especiais da Secretaria da Saúde do Estado da Bahia (COPE/SESAB), atuando no processo de elaboração dos instrumentos de planejamento governamental, principalmente no âmbito do monitoramento e avaliação da gestão. É referência técnica para a Política de Gestão Estratégica e Participativa do SUS (PARTICIPASUS) na relação com o Conselho Estadual de Saúde da Bahia.

Sisse Figueredo de Santana - Cirurgiã-dentista, especialista em Saúde da Família pela Universidade do Estado da Bahia (UNEB) e mestranda em Saúde Coletiva pela Universidade Estadual de Feira de Santana (UEFS). É pesquisadora discente na área de concentração de Políticas, Planejamento e Gestão, do Programa de Pós-Graduação em Saúde Coletiva da UEFS, inserida no Núcleo de Pesquisa Integrada em Saúde Coletiva (NUPISC/UEFS). Apoiadora Institucional da Coordenação de Projetos Especiais da Secretaria da Saúde do Estado da Bahia (COPE/SESAB). Vem desenvolvendo estudos sobre o processo de planejamento na instituição no período 2007-2010, como parte da cooperação técnica estabelecida entre a SESAB e a Organização Panamericana de Saúde (OPAS/OMS-Brasil). 



\begin{tabular}{|c|c|}
\hline & Colofão \\
\hline Formato & $17 \times 24 \mathrm{~cm}$ \\
\hline Tipologia & $\begin{array}{l}\text { Oranda BT } 11 / 16 \text { - corpo do texto } \\
\text { Corbel BT } 20 / 22 \text { - títulos }\end{array}$ \\
\hline Papel & $\begin{array}{l}\text { Alcalino } 75 \mathrm{~g} / \mathrm{m}^{2} \text { (miolo) } \\
\text { Cartão Supremo } 300 \mathrm{~g} / \mathrm{m}^{2} \text { (capa) }\end{array}$ \\
\hline Impressão & Edufba \\
\hline Capa e Acabamento & Gráfica Cian \\
\hline Tiragem & 1000 exemplares \\
\hline
\end{tabular}

